\title{
ॠUSGS
}

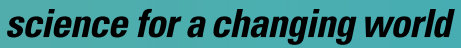

Prepared in cooperation with the Navajo Nation and the City of Flagstaff

\section{Groundwater and Surface-Water Data from the C-Aquifer Monitoring Program, Northeastern Arizona, 2012-2019}

Open-File Report 2021-1051 - i i

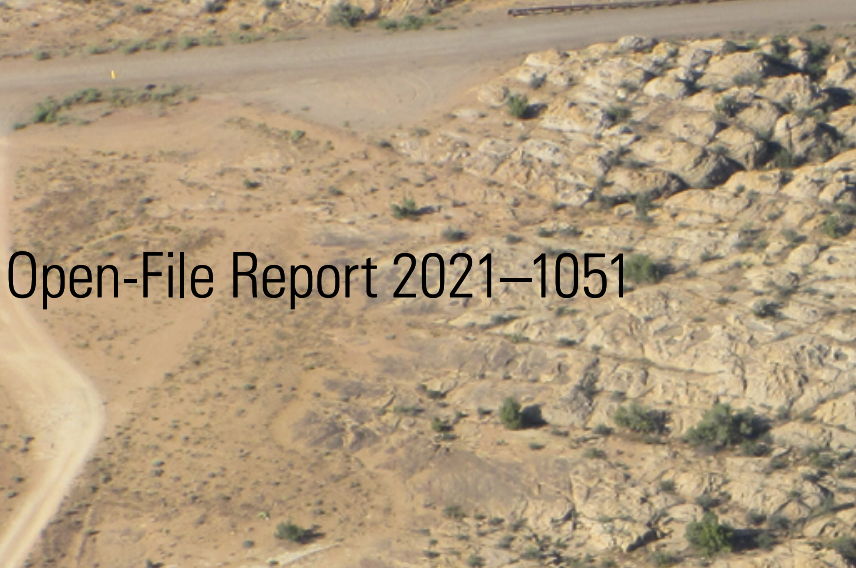

U.S. Department of the -Interior

U.S. Geological Survey

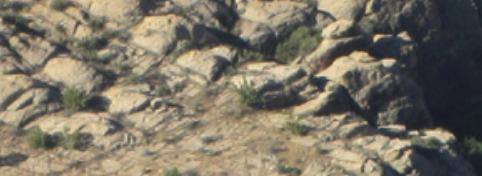

6.

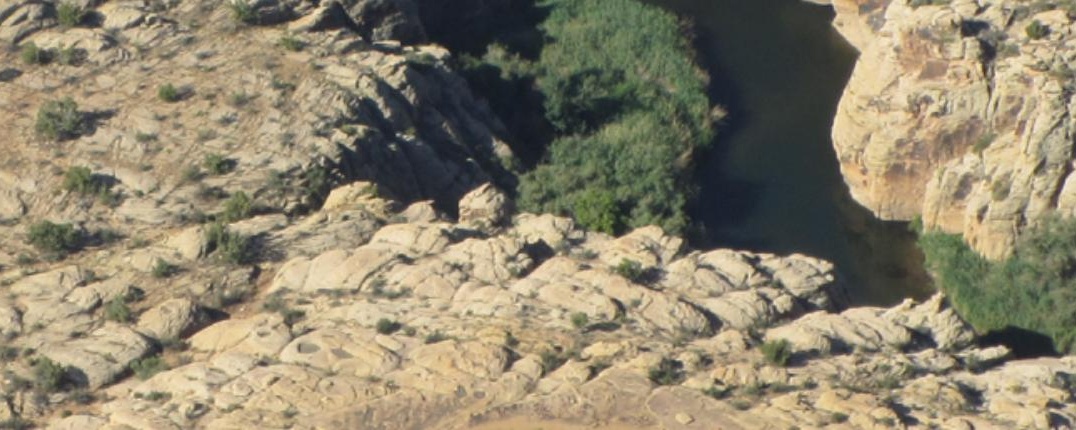


Front Cover. Aerial photograph of Chevelon bridge, located in Navajo County, Arizona. Photograph by Jon Mason, U.S. Geological Survey.

Back Cover. Photograph of a monitoring well located in Winslow, Arizona. Photograph by Casey Jones, U.S. Geological Survey. 


\section{Groundwater and Surface-Water Data from the C-Aquifer Monitoring Program, Northeastern Arizona, 2012-2019}

By Casey J.R. Jones and Michael J. Robinson

Prepared in cooperation with the Navajo Nation and the City of Flagstaff

Open-File Report 2021-1051 


\section{U.S. Geological Survey, Reston, Virginia: 2021}

For more information on the USGS — the Federal source for science about the Earth, its natural and living resources, natural hazards, and the environment-visit https://www.usgs.gov or call 1-888-ASK-USGS.

For an overview of USGS information products, including maps, imagery, and publications, visit https://store.usgs.gov.

Any use of trade, firm, or product names is for descriptive purposes only and does not imply endorsement by the U.S. Government.

Although this information product, for the most part, is in the public domain, it also may contain copyrighted materials as noted in the text. Permission to reproduce copyrighted items must be secured from the copyright owner.

Suggested citation:

Jones, C.J.R., and Robinson, M.J., 2021, Groundwater and surface-water data from the C-aquifer monitoring program, Northeastern Arizona, 2012-2019: U.S. Geological Survey Open-File Report 2021-1051, 34 p., https://doi.org/10.3133ofr20211051.

ISSN 2331-1258 (online) 


\section{Contents}

Abstract

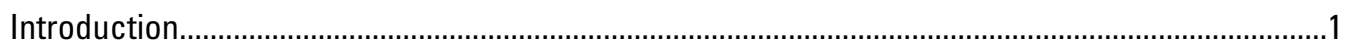

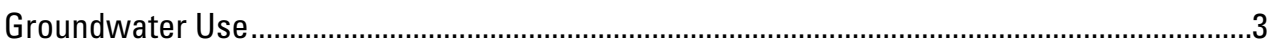

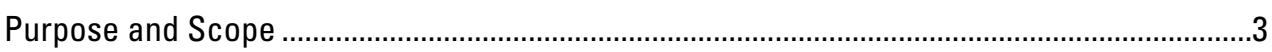

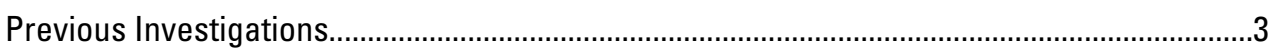

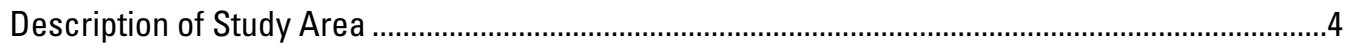

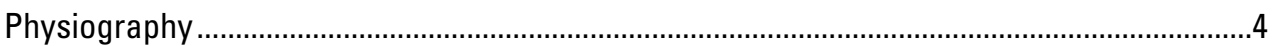

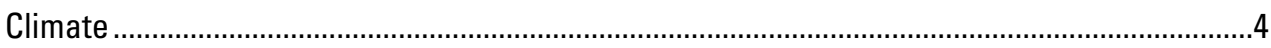

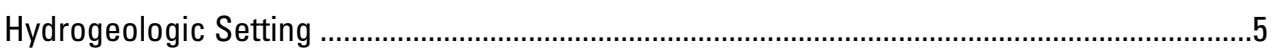

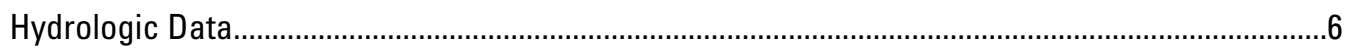

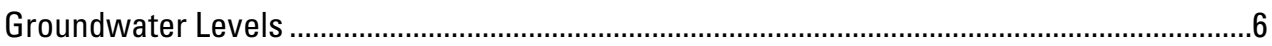

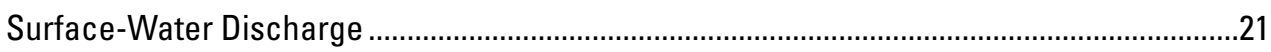

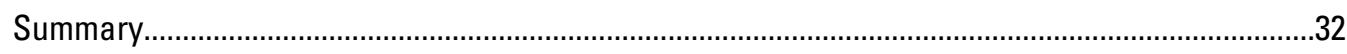

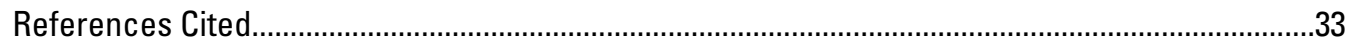

\section{Figures}

1. Map of the approximate extent of the $\mathrm{C}$ aquifer and location of the study area, northeastern Arizona ................................................................................................2

2. Generalized stratigraphic section of rock units in the study area and surrounding areas, northeastern Arizona ........................................................................................

3. Generalized hydrogeologic cross section of the Little Colorado River Basin and adjoining areas near Flagstaff, Arizona ………………...............................................

4. Map of observation wells and discontinued streamflow-gaging station sites included in this study, northeastern Arizona.......................................................................8

5. Map of water-level changes in feet of observation wells included in this study,

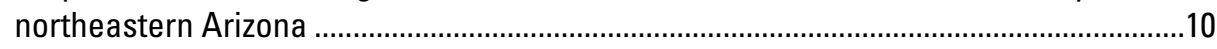

6. Graph of measured water levels in wells no longer in the observation-well network, C aquifer, northeastern Arizona.....................................................................11

7. Graph of measured water levels in wells no longer in the observation-well network, C aquifer, northeastern Arizona.....................................................................12

8. Graph of measured water levels in wells no longer in the observation-well

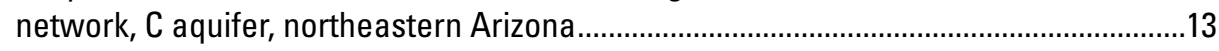

9. Graph of measured water levels in wells no longer in the observation-well network, C aquifer, northeastern Arizona..................................................................... 14

10. Graph of measured water levels in the observation-well network, $C$ aquifer, northeastern Arizona .

11. Graph of measured water levels (2005-2020) in the observation-well network, $C$ aquifer, northeastern Arizona

12. Graph of measured and continuously recorded water levels in the observation-well network, $C$ aquifer, northeastern Arizona..

13. Graph of measured and continuously recorded water levels in the observation-well network, $\mathrm{C}$ aquifer, northeastern Arizona.

14. Graph of measured and continuously recorded water levels in the observation-well network, $\mathrm{C}$ aquifer, northeastern Arizona 
15. Locations of $\mathrm{C}$-aquifer baseflow investigation sites along Clear Creek, Chevelon Creek, and the Little Colorado River, northeastern Arizona.

16. Graphs of discharge versus river miles on Clear Creek upstream of the Little Colorado River confluence, on Chevelon Creek upstream of the Little Colorado River confluence, and on the Little Colorado River from above the Chevelon Creek confluence to below the Clear Creek confluence.

18. Map of median specific conductance in microsiemens per centimeter $(\mu \mathrm{S} / \mathrm{cm})$ along perennial reaches of Clear Creek, Chevelon Creek, and the Little Colorado River.

17. Map of median specific conductance in microsiemens per centimeter along perennial reaches of Clear Creek, Chevelon Creek, and the Little Colorado River

19. Median specific conductance in microsiemens per centimeter mapped along Chevelon Creek and plotted in graph form versus river miles upstream of the confluence of Chevelon Creek with the Little Colorado River.

20. Graphs showing $\mathrm{pH}$ versus river miles on Clear Creek upstream of the Little Colorado River confluence and on Chevelon Creek upstream of the Little Colorado River confluence.

\section{Tables}

1. Well locations and selected construction data for $\mathrm{C}$-aquifer wells included in this study, northeastern Arizona

2. Water level changes for the period of record for each well

3. Clear Creek and Chevelon Creek streamflow gages and periods of record ...................21

4. Locations and description of $\mathrm{C}$-aquifer baseflow investigation sites included in this study, northeastern Arizona

5. Measured field parameters at $\mathrm{C}$-aquifer baseflow investigation sites along Clear Creek, Chevelon Creek, and the Little Colorado River, northeastern Arizona .. 


\section{Conversion Factors}

U.S. customary units to International System of Units

\begin{tabular}{|c|c|c|}
\hline Multiply & By & To obtain \\
\hline \multicolumn{3}{|c|}{ Length } \\
\hline inch (in.) & 2.54 & centimeter $(\mathrm{cm})$ \\
\hline inch (in.) & 25.4 & millimeter (mm) \\
\hline foot $(\mathrm{ft})$ & 0.3048 & meter $(\mathrm{m})$ \\
\hline mile (mi) & 1.609 & kilometer $(\mathrm{km})$ \\
\hline \multicolumn{3}{|c|}{ Area } \\
\hline acre & 4,047 & square meter $\left(\mathrm{m}^{2}\right)$ \\
\hline acre & 0.4047 & hectare (ha) \\
\hline acre & 0.4047 & square hectometer $\left(\mathrm{hm}^{2}\right)$ \\
\hline acre & 0.004047 & square kilometer $\left(\mathrm{km}^{2}\right)$ \\
\hline \multicolumn{3}{|c|}{ Volume } \\
\hline cubic foot $\left(\mathrm{ft}^{3}\right)$ & 28.32 & cubic decimeter $\left(\mathrm{dm}^{3}\right)$ \\
\hline cubic foot $\left(\mathrm{ft}^{3}\right)$ & 0.02832 & cubic meter $\left(\mathrm{m}^{3}\right)$ \\
\hline \multicolumn{3}{|c|}{ Flow rate } \\
\hline acre-foot per year (acre-ft/yr) & 1,233 & cubic meter per year $\left(\mathrm{m}^{3} / \mathrm{yr}\right)$ \\
\hline acre-foot per year (acre-ft/yr) & 0.001233 & cubic hectometer per year $\left(\mathrm{hm}^{3} / \mathrm{yr}\right)$ \\
\hline cubic foot per second $\left(\mathrm{ft}^{3} / \mathrm{s}\right)$ & 0.02832 & cubic meter per second $\left(\mathrm{m}^{3} / \mathrm{s}\right)$ \\
\hline
\end{tabular}

Temperature in degrees Celsius $\left({ }^{\circ} \mathrm{C}\right)$ may be converted to degrees Fahrenheit $\left({ }^{\circ} \mathrm{F}\right)$ as follows:

$$
{ }^{\circ} \mathrm{F}=\left(1.8 \times{ }^{\circ} \mathrm{C}\right)+32 \text {. }
$$

Temperature in degrees Fahrenheit $\left({ }^{\circ} \mathrm{F}\right)$ may be converted to degrees Celsius $\left({ }^{\circ} \mathrm{C}\right)$ as follows:

$$
{ }^{\circ} \mathrm{C}=\left({ }^{\circ} \mathrm{F}-32\right) / 1.8 \text {. }
$$




\section{Datum}

Vertical coordinate information is referenced to the North American Datum of 1983 (NAD 83).

Horizontal coordinate information is referenced to the North American Datum of 1983 (NAD 83).

Altitude, as used in this report, refers to distance above the vertical datum.

\section{Supplemental Information}

Specific conductance is given in microsiemens per centimeter at 25 degrees Celsius $(\mu \mathrm{S} / \mathrm{cm}$ at $\left.25^{\circ} \mathrm{C}\right)$.

Concentrations of chemical constituents in water are given in either milligrams per liter (mg/L) or micrograms per liter $(\mu \mathrm{g} / \mathrm{L})$.

\section{Abbreviations}

$\begin{array}{ll}\text { ADWR } & \text { Arizona Department of Water Resources } \\ \text { BIA } & \text { Bureau of Indian Affairs } \\ \text { ENSO } & \text { El Niño-Southern Oscillation } \\ \text { I-40 } & \text { Interstate } 40 \\ \text { NWIS } & \text { USGS National Water Information System } \\ \text { PDO } & \text { Pacific Decadal Oscillation } \\ \text { USGS } & \text { U.S. Geological Survey } \\ \text { WY } & \text { water year }\end{array}$




\title{
Groundwater and Surface-Water Data from the C-Aquifer Monitoring Program, Northeastern Arizona, 2012-2019
}

\author{
By Casey J.R. Jones and Michael J. Robinson
}

\section{Abstract}

The Coconino aquifer ( $\mathrm{C}$ aquifer) is a regionally extensive multiple-aquifer system supplying water for municipal, agricultural, and industrial use in northeastern Arizona, northwestern New Mexico, and southeastern Utah. This report focuses on the $\mathrm{C}$ aquifer in the arid to semi-arid area between St. Johns, Ariz., and Flagstaff, Ariz., along the Interstate-40 corridor where an increase in groundwater withdrawals coupled with ongoing drought conditions increase the potential for substantial waterlevel decline within the aquifer.

The U.S. Geological Survey (USGS) C-aquifer Monitoring Program began in 2005 to establish baseline groundwater and surface-water conditions and to quantify physical and water-chemistry responses to pumping stresses and climate. This report presents data previously reported in Brown and Macy (2012) that extend back as far as the 1950s, along with new data collected from the USGS C-aquifer Monitoring Program since that publication, from water years 2012 to 2019.

Water levels in 17 wells are measured quarterly as part of the $\mathrm{C}$-aquifer Monitoring Program, and five of those are continuously monitored at 15-minute intervals. Water levels in an additional 18 wells in the study area are measured periodically by the USGS or other agencies. The largest historical change in water level in the study area was a decrease of 81.20 feet in Lake Mary 1 Well near Flagstaff between 1962 and 2018. Changes in water levels were greatest around major pumping centers and in the eastern extent of the study area.

Surface-water water-quality parameters $(\mathrm{pH}$, water temperature, specific conductance, and dissolved oxygen) and streamflow discharge measurements were collected and analyzed along perennial, groundwater-fed reaches of Clear Creek, Chevelon Creek, and the Little Colorado River during nine baseflow investigations of varying extent between 2005 and 2019. Both Clear Creek and Chevelon Creek gain in flow from the beginning of their perennial reaches to their outflow into the Little Colorado River. The Little Colorado River has relatively steady streamflow in the reach between where the two tributaries enter the river. Chevelon Creek showed an increase in median specific conductance during all baseflow investigations of nearly 4,000 microsiemens per centimeter $(\mu \mathrm{S} / \mathrm{cm})$ from near the headwaters to the confluence with the Little Colorado River; Clear Creek also showed an increase in median specific conductance of almost 5,000 $\mu \mathrm{S} / \mathrm{cm}$ from headwaters to confluence. Water temperature, dissolved oxygen, and $\mathrm{pH}$ do not show substantial trends along the reaches of Clear Creek, Chevelon Creek, or the Little Colorado River.

\section{Introduction}

The Coconino aquifer, referred to hereinafter as the $\mathrm{C}$ aquifer, is a multiple-aquifer system that extends throughout northeastern Arizona, northwestern New Mexico, and southeastern Utah (fig. 1). This report focuses on the $\mathrm{C}$ aquifer in the area between St. Johns, Ariz., and Flagstaff, Ariz., along the Interstate 40 (I-40) corridor in Arizona and within the Little Colorado River Basin. Groundwater from the $\mathrm{C}$ aquifer is used for municipal, agricultural, and industrial purposes in the Little Colorado River Basin. In some areas, the $\mathrm{C}$ aquifer intersects with the surface and provides stream baseflow via spring discharge. Perennial reaches, supported by groundwater discharge, of Clear Creek, Chevelon Creek, and the Little Colorado River provide habitat for many species; the lower eight miles of Chevelon Creek are designated as critical habitat for the threatened Lepidomeda vittata (Little Colorado spinedace; US Fish and Wildlife, 1987; Southwest Ground-water Consultants, Inc., 2015). Increases in groundwater withdrawals and (or) drought conditions have been reported to cause a lowering of the $\mathrm{C}$-aquifer potentiometric and water-table surfaces (Bills and others, 2000). Proposed increases in groundwater withdrawals to meet demands from population growth in Flagstaff and other communities along the I-40 corridor coupled with ongoing drought conditions in the study area increase the potential for additional water-level declines within the aquifer. To address these concerns, the U.S. Geological Survey (USGS), in cooperation with the Navajo Nation (2005-present) and the City of Flagstaff (2012-present), developed a long-term plan for the $\mathrm{C}$ aquifer to monitor groundwater and surfacewater conditions in the area. Groundwater, surface-water, and water-quality data collected from the beginning of water year (WY) 2005 through the end of WY 2011 are presented in Brown and Macy (2012). This report presents data through the end of WY 2019. Changes in water use and climate are two reasons to continue monitoring the $\mathrm{C}$-aquifer system. $\mathrm{C}$-aquifer monitoring data will allow quantification of physical and water-chemistry responses to the stressors of pumping and climate change. 


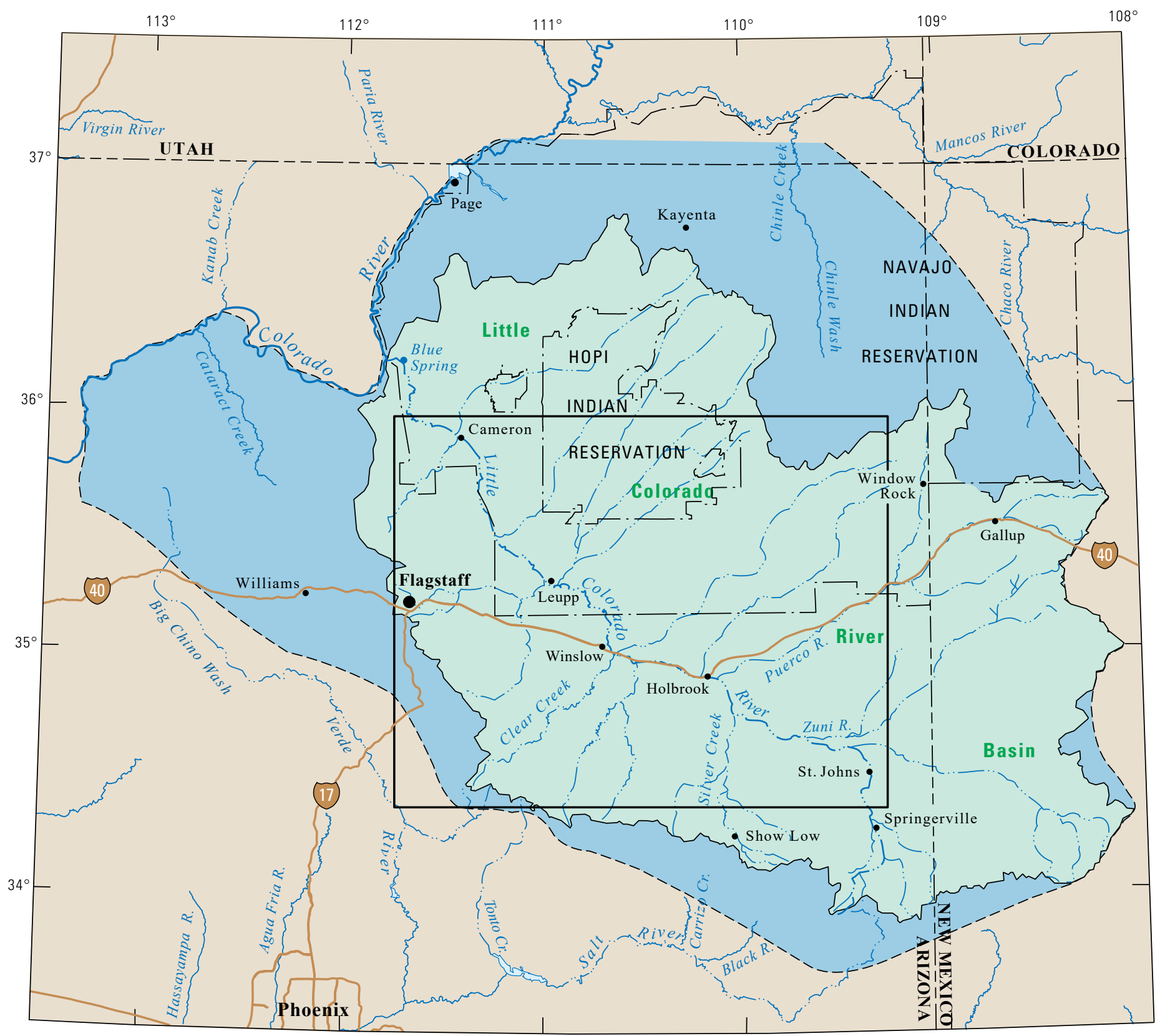

Base from U.S. Geological Survey digital data, 1:100,000, 1980. Albers Equal Area Conic projection. Standard parallels $29^{\circ} 30$ and $45^{\circ} 30^{\prime}$, central meridian $111^{\circ} 30^{\prime}$.

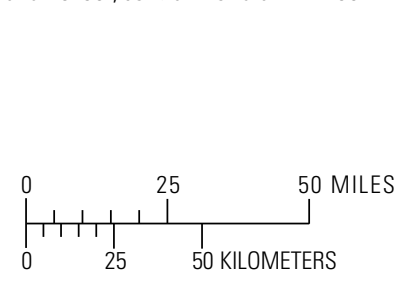

\section{EXPLANATION}
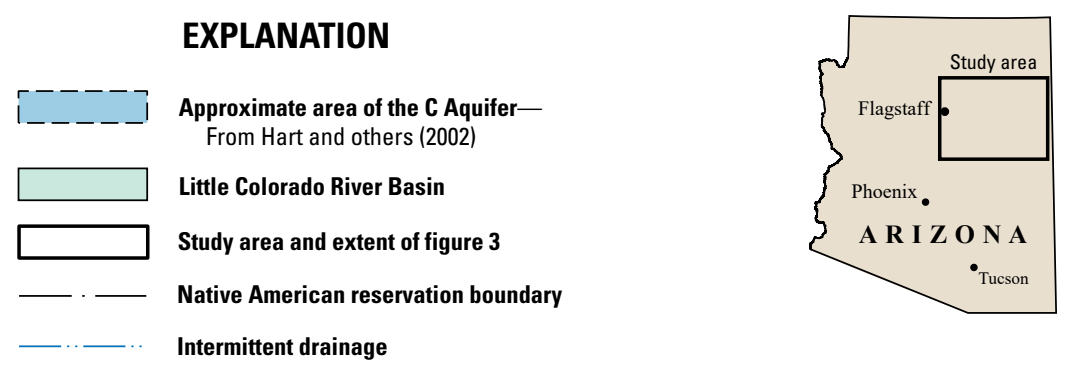

Interstate highway

Figure 1. Map of the approximate extent of the $\mathrm{C}$ aquifer and location of the study area, northeastern Arizona. Modified from Hoffmann and others, 2006. 


\section{Groundwater Use}

Groundwater development of the $\mathrm{C}$ aquifer has increased in the study area since the 1940s (Hart and others, 2002). Currently, the Navajo Nation, the cities of Flagstaff, Winslow, and Holbrook (including their surrounding communities), and three regional power plants are users of C-aquifer water (S.S. Papadopulos and Associates, Inc., 2005). The three power plants are Cholla Power Generating Plant in Joseph City, Coronado Generation Station near St. Johns, and Springerville Generation Station in Springerville. Brown and Macy (2012) noted another user, a large paper mill near Snowflake, which has since closed and ceased water usage.

\section{Purpose and Scope}

This report presents new groundwater, surface-water, and water-quality data collected from the beginning of WY 2012 through the end of WY 2019 from ongoing monitoring of the C aquifer near St. Johns, Ariz., along the I-40 corridor westward to Flagstaff, Ariz. Historical water-level data dating back to 1952 from wells developed in the $\mathrm{C}$ aquifer also are included. Groundwater data presented include water levels from 35 wells completed in the $\mathrm{C}$ aquifer. 17 of the wells are measured quarterly by the USGS with some observations for the remaining wells provided by private owners as well as government agencies, including Arizona Department of Water Resources (ADWR) and the City of Flagstaff. Surface-water discharge measurements and water-quality data are from nine baseflow investigations of varying extent conducted on perennial reaches of Clear Creek, Chevelon Creek, and the Little Colorado River between WY 2005 and WY 2019.

\section{Previous Investigations}

$\mathrm{C}$-aquifer hydrogeology and water use in the area have been described in several USGS and non-USGS reports. Darton (1910) compiled some of the first geologic data between Kingman, Ariz., and Albuquerque, N. Mex., to explore groundwater prospects for the Atchison, Topeka, and Santa Fe Railway. Gregory (1916) described the geography, climate, surface water, and groundwater of the Navajo and Hopi Reservations; the hydrogeology in this area was later expanded upon by Cooley and others (1969). Harrell and Eckel (1939) presented a comprehensive groundwater study of the Holbrook area, including chemical analyses from 118 wells and springs. Babcock and Snyder (1947) also evaluated groundwater resources in the Holbrook area. In southern Navajo County, Mann described groundwater conditions as well as developed a water budget and mathematical model (1976 and 1979, respectively). Additional hydrologic studies were completed for the Snowflake-Hay Hollow area, southern Apache County, and southern Coconino County (Johnson, 1962; Mann and Nemecek, 1983; McGavock and others, 1986, respectively). Bills and others (2000) studied the complex, regional $\mathrm{C}$ aquifer in Flagstaff using water chemistry and several geophysical methods to associate fracturing and structural deformation with high well yields. They found that near Flagstaff, water levels in the Lake Mary well field had declined approximately $100 \mathrm{ft}$ in the 34 years before 1997 and water levels in the Woody Mountain well field had declined about $35 \mathrm{ft}$ in the 42 years before 1997. They related these declines to pumping. When structural deformation was minimal or absent, other wells in the $\mathrm{C}$ aquifer had no response to climate or pumping during the study. Bills and Flynn (2002) compiled hydrologic and geophysical data for the entire Coconino Plateau and adjacent areas. Additional data for this area were collected and analyzed by Bills and others (2007) to develop a groundwater budget and conceptual model for the combined $\mathrm{C}$ and Redwall-Muav aquifers.

Hart and others (2002) compiled existing C-aquifer data in the Little Colorado River Basin and parts of the Verde and Salt River Basins to produce a generalized groundwater budget. They estimated that the total discharge from the $\mathrm{C}$ aquifer during steady-state conditions is 319,000 acre feet per year (acre-ft/yr), with most of the discharge leaking downward to the hydraulically connected Redwall-Muav aquifer. Private consulting firms (Peter Mock Groundwater Consulting, 2003; Southwest Ground-water Consultants, Inc., 2003) prepared a collaborative report for the Bureau of Reclamation assessing the water-supply needs of the western part of the Hopi Tribal Lands and the Navajo Nation. The report contains estimates of population growth and water demand for the study area through 2050. Suggestions for enhanced conservation practices and possible alternative water sources are made. Geological, hydrological, and chemical data from the $\mathrm{C}$ aquifer near Leupp, Ariz., were analyzed and presented by Hoffmann and others (2006) as part of a collaborative study conducted by the Bureau of Reclamation, the USGS, the U.S. Fish and Wildlife Service, the Office of Surface Mining, and Native American tribes in order to assess the effects of proposed new developments.

Beginning in the early 2000s, several numerical groundwater-flow models were developed to represent the $\mathrm{C}$ aquifer. Leake and others (2005) created a numerical groundwater change model to simulate possible effects of proposed withdrawals from the $\mathrm{C}$ aquifer near Leupp. The model used two pumping scenarios to simulate the amount of discharge depletion for surface-water features including Clear Creek, Chevelon Creek, and the Little Colorado River. The model showed that computed depletion in lower Chevelon Creek during the simulation period was less than that in lower Clear Creek because Chevelon Creek is more distant from the withdrawal locations, and the drawdown first reaches Clear Creek. Another groundwater-flow model of the $\mathrm{C}$ aquifer in northeastern Arizona and northwestern New Mexico was developed by S.S. Papadopulos and Associates, Inc. (2005). This model also simulates the possible effects of a proposed increase in withdrawals from the $\mathrm{C}$ aquifer near Leupp. The model shows little effect on wells outside the proposed well field, but substantial effect on perennial reaches of Chevelon Creek and Clear Creek for the pumping scenarios tested. The City of Flagstaff commissioned AMEC Geomatrix, Inc. as part of a groundwater sustainability study and to update the City of Flagstaff's Designation of Adequate Water Supply 
with ADWR (AMEC Geomatrix, Inc, 2012). Southwest Groundwater Consultants, Inc., used this model as a base to build upon for the Red Gap Ranch-Leupp Groundwater Flow Model to assess future groundwater withdrawals from Red Gap Ranch and the Navajo Nation-Leupp well field on baseflow in Clear Creek, Chevelon Creek, and the Little Colorado River. For several pumping scenarios, no substantial difference in streamflow is predicted in Chevelon Creek. For the maximum pumping scenario, Clear Creek has an estimated decrease in flow of 0.08 cubic feet per second $\left(\mathrm{ft}^{3} / \mathrm{s}\right)$ and the Little Colorado River has an estimated decrease in flow of $0.2 \mathrm{ft}^{3} / \mathrm{s}$ (Southwest Groundwater Consultants, 2015). Pool (2016) uses the Northern Arizona Regional Groundwater Flow Model (Pool and others, 2011) to evaluate changes in groundwater levels and groundwater discharge to streams and springs from the $\mathrm{C}$ and Redwall-Muav aquifers. Based on a scenario with no major changes in groundwater use except for an increase in demand based on population projections, by 2105 groundwater levels are predicted to decline more than $100 \mathrm{ft}$ near major withdrawal wells (such as the City of Flagstaff), rise more than $100 \mathrm{ft}$ near recharge areas (such as the City of Flagstaff Waste-Water Treatment Plants), decline between 10 and $50 \mathrm{ft}$ near Leupp and Red Gap Ranch, and decline 1 to $5 \mathrm{ft}$ for much of the remaining study area. In the same period, Clear Creek is predicted to lose less than $0.1 \mathrm{ft}^{3} / \mathrm{s}$ and Chevelon Creek is predicted to increase in flow by $0.3 \mathrm{ft}^{3} / \mathrm{s}$. Other model scenarios include a pipeline that would provide surface water from Lake Powell to curb reliance on groundwater withdrawals. Unlike the previous two models described, this model does not use refined grid spacing, potentially resulting in less accuracy.

Brown and Macy (2012) presents monitoring data from a study of the St. Johns to Flagstaff I-40 corridor area beginning in 2005 in cooperation with the Bureau of Indian Affairs (BIA). The report includes WY 2005 to WY 2011 groundwater levels from $35 \mathrm{C}$-aquifer wells, surface-water discharge data from three now-discontinued streamflow-gaging stations, comprehensive water-chemistry analyses from selected well sites and surface-water sites, and water-quality field parameters and discharge measurements from four baseflow investigations conducted on reaches of Clear Creek, Chevelon Creek, and the Little Colorado River. The City of Flagstaff became an additional cooperator on this project in 2012 . This current report is the second published on the C-Aquifer Monitoring Program and includes supplementary data from WY 2012 to the end of WY 2019.

\section{Description of Study Area}

The C-aquifer multiple-aquifer system is in the Colorado Plateau physiographic province in northeastern Arizona, northwestern New Mexico, and southeastern Utah (fig. 1). The study area is within the Little Colorado River Basin in the southern part of the Colorado Plateau (Fenneman, 1946), and focuses on the area between St. Johns, Ariz., and Flagstaff, Ariz., along the I-40 corridor. The physiography, climate, and hydrogeology interact to control water resources in this area.

\section{Physiography}

The $\mathrm{C}$ aquifer has an areal extent of greater than $27,000 \mathrm{mi}^{2}$, generally conforming to the surface-water drainage of the Little Colorado River Basin (fig. 1; Hart and others, 2002; Hoffmann and others, 2006). The aquifer extends beyond the southern boundary of the Little Colorado River Basin into the Verde and Salt River Basins, conforming to the outcrops of Pennsylvanian and Permian age rocks, and beyond the north-northwestern boundary of the Little Colorado River Basin into Utah (fig. 1).

Humphreys Peak on San Francisco Mountain near Flagstaff, the eroded remains of a stratovolcano, is not only the highest elevation in the Little Colorado River Basin but also the highest point in Arizona at 12,633 ft; however, most topography in the Little Colorado River Basin is developed on nearly horizontal sedimentary rocks around $5,000 \mathrm{ft}$ in elevation (Hart and others, 2002). Local topographic relief is provided by folds, monoclines, and canyons, especially around the margins of the Little Colorado River Basin (Hart and others, 2002). The Holbrook subbasin, to the eastern extent of the Little Colorado River Basin, contains more than 500 evaporite-karst depressions (Conway and Cook, 2013). Many sinkholes are present along the Holbrook anticline (Neal and Johnson, 2002). The Holbrook anticline originates about 20 miles southeast of Winslow and extends around 60 miles southwestward (Mann, 1976). The Holbrook anticline is paralleled by the Dry Lake syncline to the south (Mann, 1976). Both Clear Creek and Chevelon Creek in the study area flow through incised canyons in the Coconino Sandstone.

\section{Climate}

The climate in the study area ranges from arid desert in low valleys to subarctic in the high mountains near Flagstaff (Hart and others, 2002). Most of the area of focus is classified as arid or semi-arid (Bills and others, 2007). Climate in the southwestern United States is affected interannually by the El Niño-Southern Oscillation (ENSO). Warmer sea surface temperatures during El Niño are correlated with greater than average winter precipitation, while cooler sea surface temperatures during La Niña are correlated with below average winter precipitation (Goodrich, 2004). The Pacific Decadal Oscillation (PDO) influences climate and ENSO on a multidecadal scale (Goodrich, 2004; McCabe and others, 2004). Like much of the surrounding region, the study area has been in an extended drought since the late 1990s (Bills and others, 2007; McCabe and others, 2004). As of November 2019 , the study area continues to be classified as in moderate to severe drought (US Drought Monitor, 2019).

Precipitation in the study area varies seasonally. In the wet season, typically between July and September, rain occurs frequently as an effect of the North American monsoon (Adams and Comrie, 1997). Between November and April precipitation generally occurs as snow over much of the study area. Precipitation also varies with altitude. The average annual precipitation near Winslow was less than 10 inches (in) 
between 1981 and 2010 (PRISM Climate Group, 2018). In the higher elevations near Flagstaff, average annual precipitation was more than 30 in (Bills and others, 2000; PRISM Climate Group, 2018).

Mean monthly temperature values between 1981 and 2010 near Winslow were highest in July and August at more than $75^{\circ} \mathrm{F}$, with the lowest temperatures in December and January at around $35^{\circ} \mathrm{F}$ (PRISM Climate Group, 2018). Near Flagstaff, mean monthly temperature values range from more than $65^{\circ} \mathrm{F}$ in the summer months to near $30^{\circ} \mathrm{F}$ in winter; average temperatures are about ten degrees cooler year-round on the flanks of San Francisco Mountain. (PRISM Climate Group, 2018).

\section{Hydrogeologic Setting}

The $\mathrm{C}$ aquifer is named after the primary water-bearing rock unit within the aquifer, the Coconino Sandstone, but the saturated and hydraulically connected parts of the Kaibab Formation, Toroweap Formation, and the upper and middle part of the Supai Formation also constitute part of the $\mathrm{C}$ aquifer (fig. 2; Bills and others, 2000; Bills and Flynn, 2002; Hart and

Figure 2. Generalized stratigraphic section of rock units in the study area and surrounding areas, northeastern Arizona. Solid lines represent known contacts, dashed lines represent informal contacts, and the sawtooth lines represent intertonguing contacts.

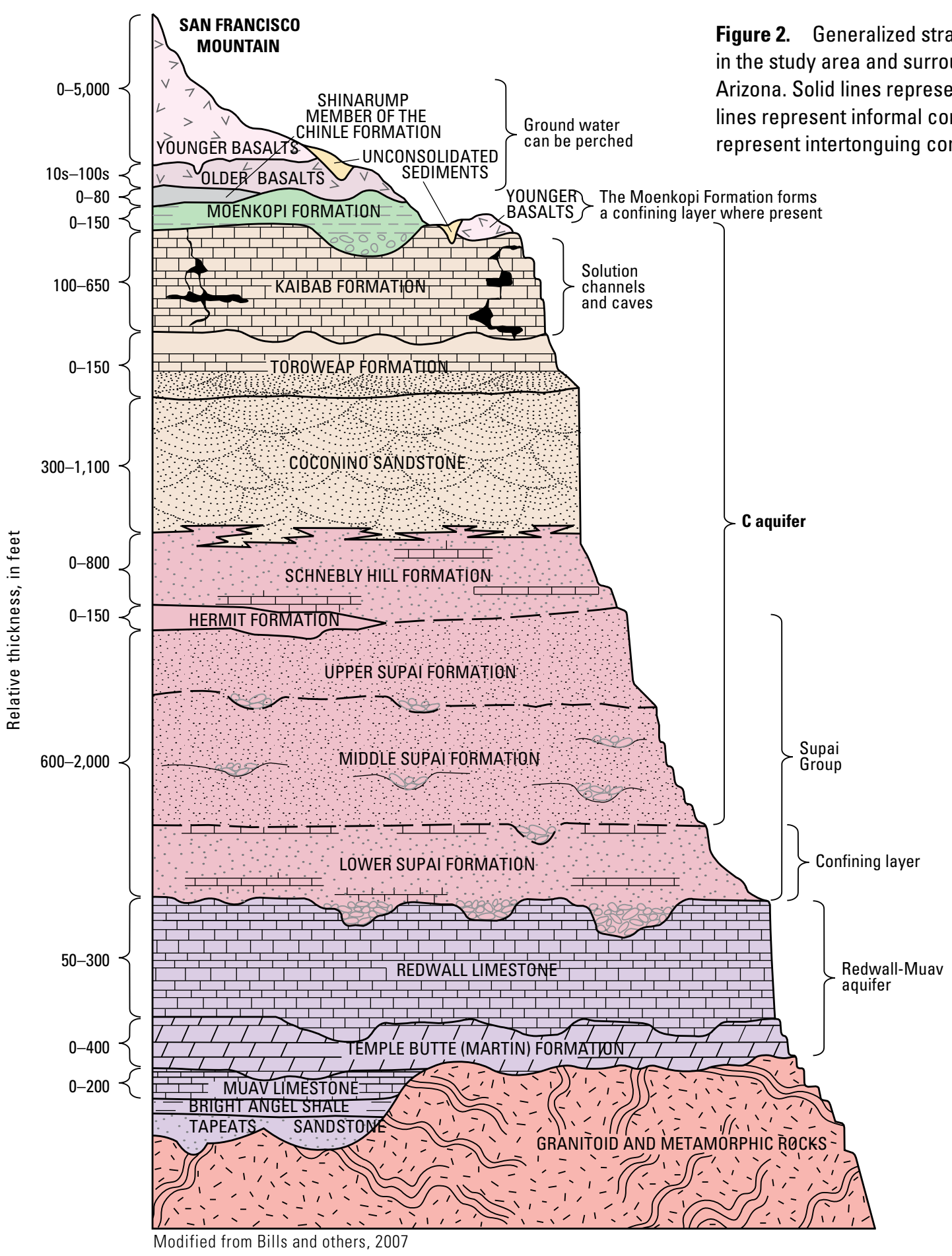


others, 2002). The lateral equivalents of the Coconino Sandstone throughout the $\mathrm{C}$ aquifer are the Glorieta Sandstone and the De Chelly Sandstone of the Cutler Group; these units are typically the main water-bearing units of the aquifer (Hart and others, 2002). The Schnebly Hill Formation also becomes an important C-aquifer component near Flagstaff (Bills and others, 2000). East of Holbrook, the Corduroy Member of the Schnebly Hill Formation contains evaporites of early Permian age as much as $650 \mathrm{ft}$ thick (Conway and Cook, 2013).

The $\mathrm{C}$ aquifer is anisotropic and unconfined in most of the study area; however, portions of the $\mathrm{C}$ aquifer are overlain by less permeable units of the Moenkopi, the Chinle, and the Bidahochi Formations, and by unfractured volcanic rocks (fig.3) (Bill and others, 2000; S.S. Papadopulos and Associates, Inc., 2005). These formations are confining layers, with negligible amounts of downward leakage to the $\mathrm{C}$ aquifer and thus most of recharge to the $\mathrm{C}$ aquifer occurs at subaerial exposures or where the surface lithology is fractured (Hart and others, 2002).

Below the $\mathrm{C}$ aquifer is the Redwall-Muav aquifer, which consists of Redwall Limestone, Temple Butte and Martin Formation, and Muav Limestone (Bills and others, 2000; Hart and others, 2002). The Redwall-Muav aquifer supplies spring discharge along the edges of the study area at the Mogollon Rim, and to the lower Little Colorado River and Blue Spring. The $\mathrm{C}$ aquifer may be hydrologically connected to the Redwall-Muav aquifer where the former is fractured, allowing downward leakage (Hart and others, 2002). However, the Redwall-Muav aquifer does not outcrop in the focus area of this study, and any leakage is difficult to quantify.

\section{Hydrologic Data}

$\mathrm{C}$-aquifer hydrologic data for this report include groundwater levels from wells drilled into the aquifer and surfacewater discharges and field parameters $(\mathrm{pH}$, specific conductance, dissolved oxygen, and water temperature) from Clear Creek, Chevelon Creek, and the Little Colorado River. Discrete groundwater measurements were taken by USGS personnel unless otherwise indicated. Five continuously-recording observation wells are part of the C-aquifer Monitoring Program and data are available online in the USGS National Water Information System (NWIS) database (http://waterdata.usgs.gov/nwis/ $\mathrm{gw})$. Discharge values and water-chemistry parameters for baseflow investigation sites are also available online (https:// waterdata.usgs.gov/nwis/measurements and https://nwis.waterdata.usgs.gov/nwis/qw, respectively).

\section{Groundwater Levels}

Groundwater levels are monitored to determine the effects of withdrawal and drought on the C-aquifer potentiometric and water-table surfaces. The well network within the $\mathrm{C}$-aquifer Monitoring Program consists of 17 wells centralized around and to the northwest of Winslow (fig. 4). Since 2006, these wells have been visited quarterly by USGS personnel to take water-level measurements. All measurements taken by the USGS are in accordance with methodologies described in the Groundwater Technical Procedures of the U.S. Geological Survey (Cunningham and Schalk, 2011). Depthto-water is measured from an established measuring point at the well head using a calibrated electric measuring tape. The measuring point height above land surface datum is then subtracted from the total measurement to get depth-to-water in feet below land surface datum (ft bls). Thus, depth-to-water has an inverse relationship to water level. As depth-to-water increases, the water level decreases. Data for these 17 wells along with an additional 18 wells were included in Brown and Macy (2012). The additional wells span a larger area from near St. Johns to north of Flagstaff. (fig. 4; table 1). From 2005 to 2006, all 35 wells were monitored by the USGS as part of the C-Aquifer Monitoring Program. In 2006 the number of wells in the C-Aquifer Monitoring Program was reduced to the 17 current wells because of a decrease in funding. Water levels at the 18 wells not within the current monitoring program are recorded sporadically by other agencies which include ADWR, the City of Flagstaff, and individual owners. The quality of data collected by agencies or individuals other than USGS cannot be guaranteed to USGS standards. The waterlevel data for these 18 wells are included in this report when available and are plotted, along with data from the 17 network wells, to determine changes in water level versus time (figs. 5-11).

Of the 17 active wells in the C-Aquifer Monitoring Program, 3 are stand-alone wells and the other 14 are in one of three clusters. The three stand-alone wells are the Winslow T-Well, the I-40 Well, and the Sunshine Well. The Winslow T-Well is located approximately 7 miles southwest of Winslow, and the I-40 Well is located approximately 5.5 miles east of Winslow on the north side of I-40. The Sunshine Well is west of Winslow on I-40, just north of the Meteor Crater Road exit 233. The 14 remaining wells are condensed into three clusters, labeled Site 1, Site 2, and Site 3 (fig. 4; table 2). These clusters are located on the Navajo Nation Reservation south of Leupp, roughly along Highway 99. 
WEST

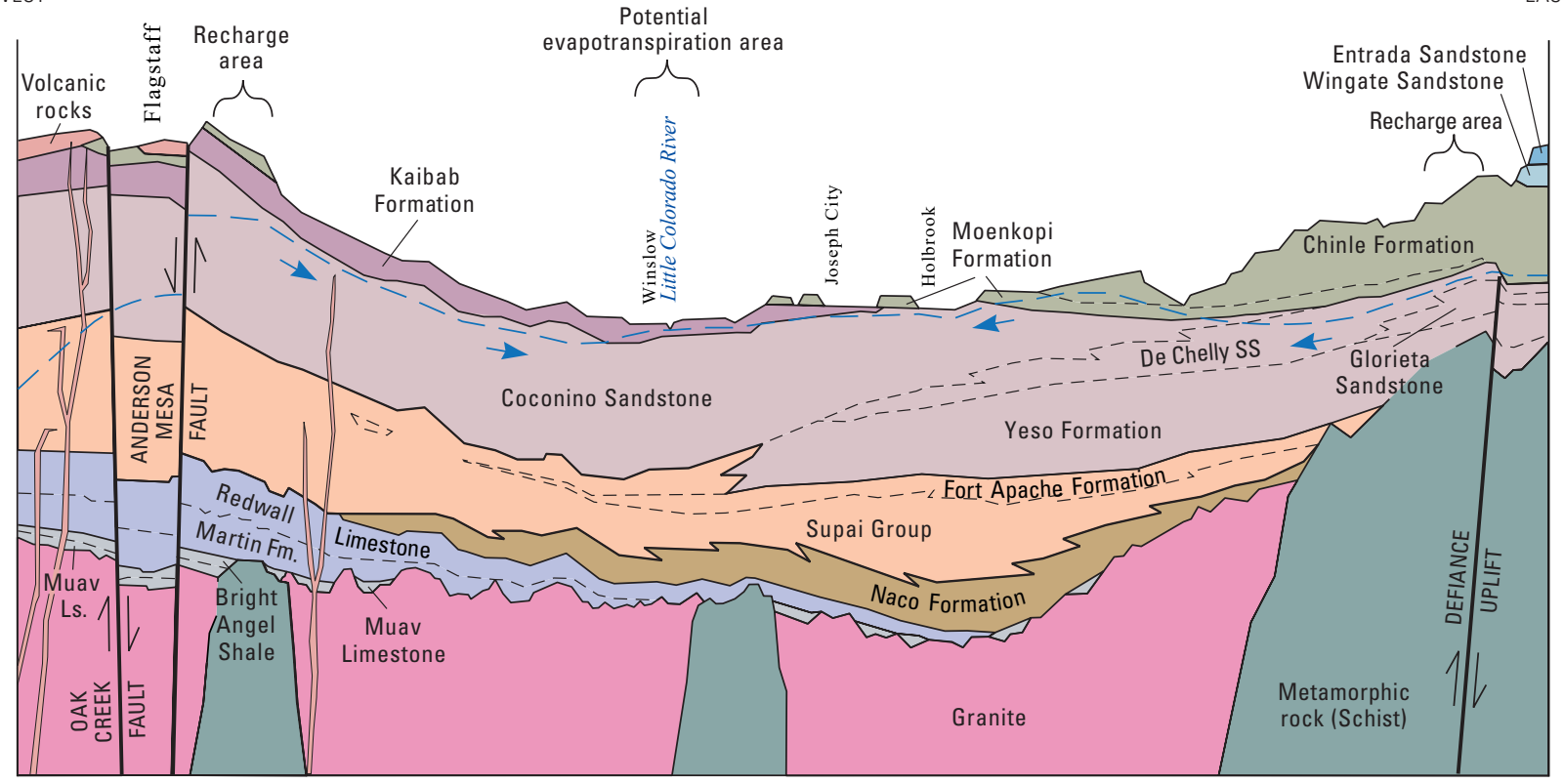

\section{EXPLANATION}

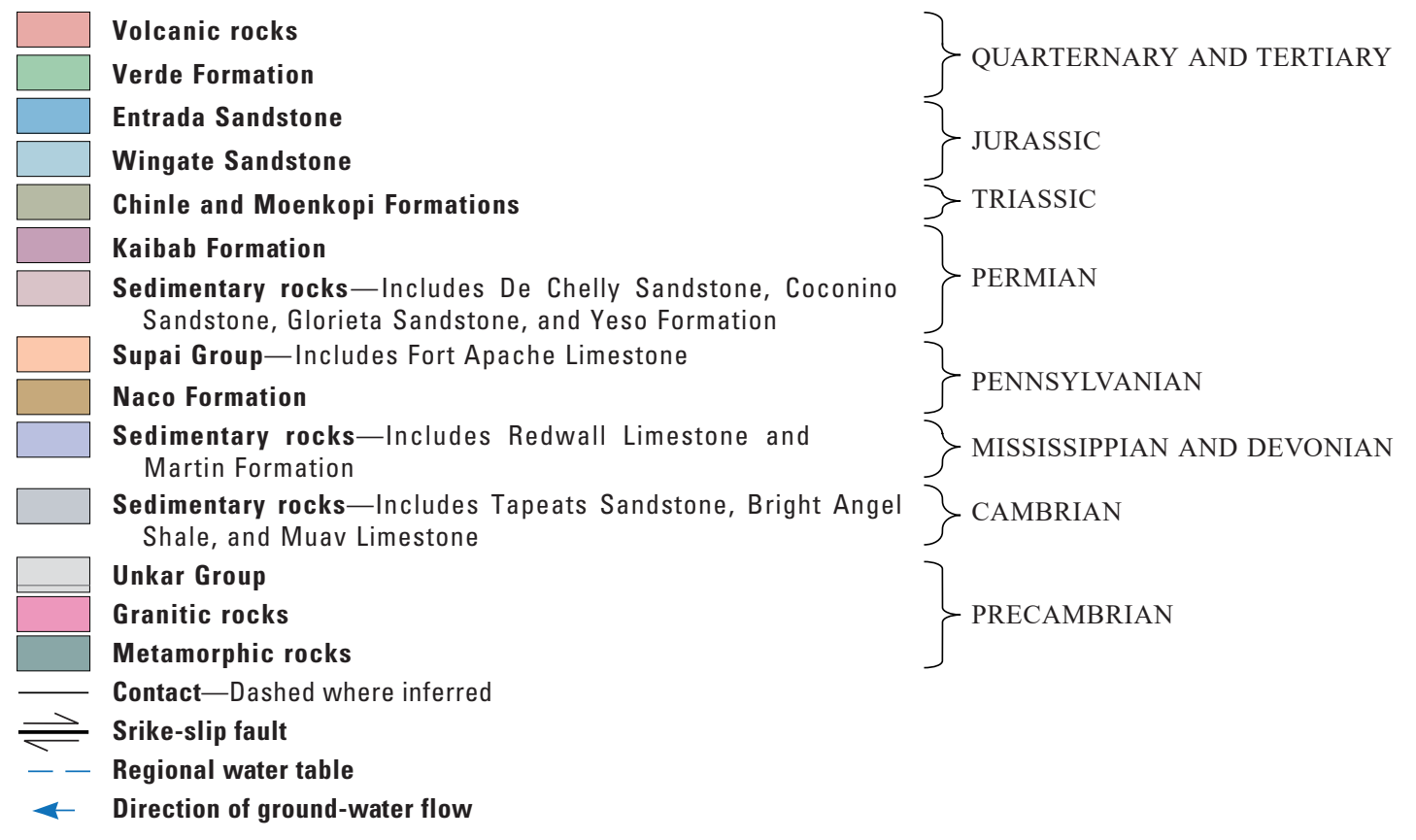

Figure 3. Generalized hydrogeologic cross section of the Little Colorado River Basin and adjoining areas near Flagstaff, Arizona, along Interstate 40 to the Arizona-New Mexico border. Modified from Billingsley and others (1980) and Hart and others (2002). 


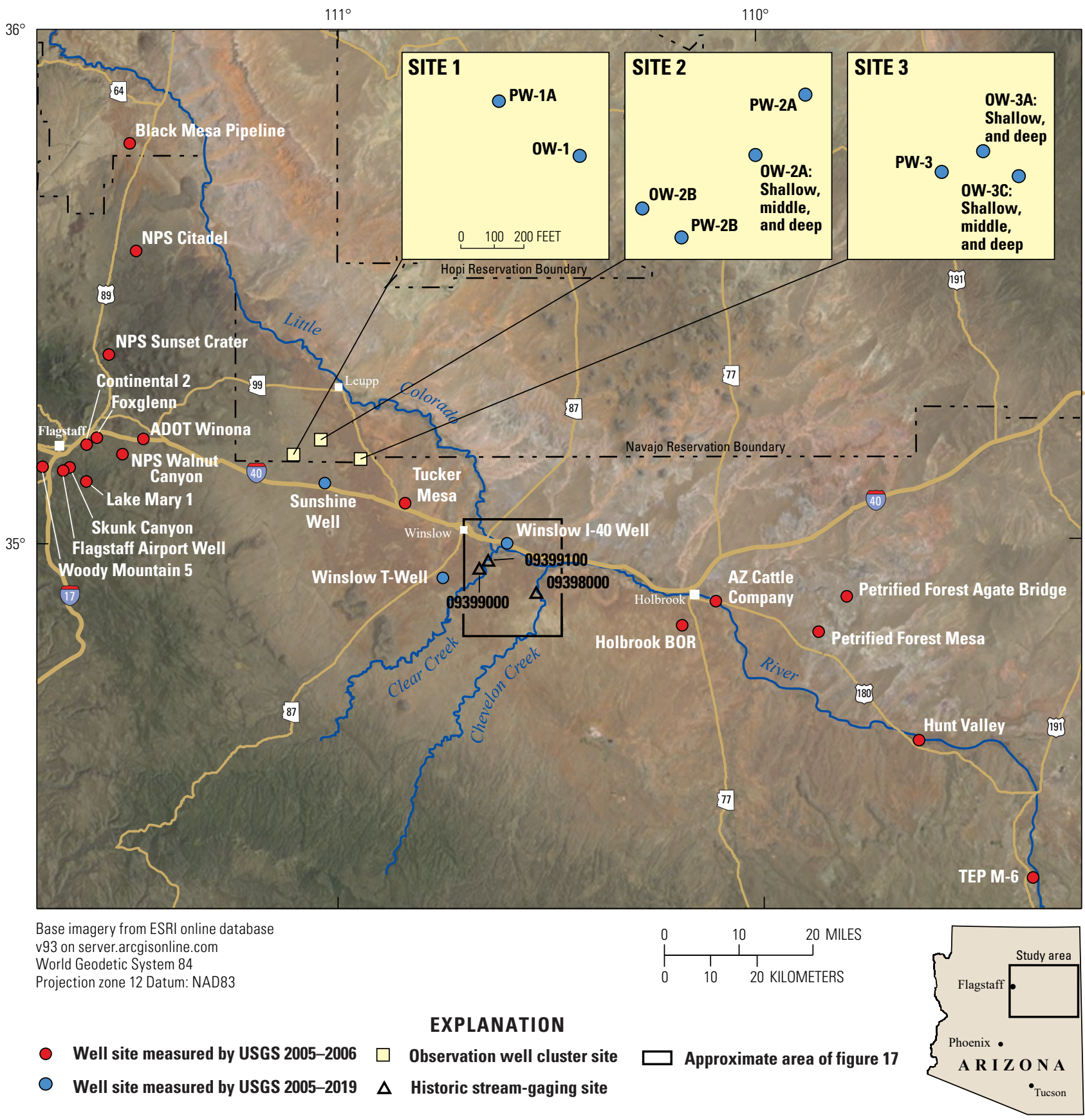

Figure 4. Map of observation wells and discontinued streamflow-gaging station sites included in this study, northeastern Arizona. A detailed view of the well cluster sites near Leupp is shown. Sections modified from Hoffmann and others, 2006. 
Table 1. Well locations and selected construction data for $\mathrm{C}$-aquifer wells included in this study, northeastern Arizona.

[Latitude and longitude are in degrees, minutes, and seconds and referenced to NAD 83; ft, feet; ft bls, feet below land surface; dashes, information not available; N/A, not applicable]

\begin{tabular}{|c|c|c|c|c|c|c|c|}
\hline $\begin{array}{c}\text { U.S. Geological } \\
\text { Survey } \\
\text { identification } \\
\text { number }\end{array}$ & $\begin{array}{l}\text { Bureau of Reclamation } \\
\text { designation or } \\
\text { common name }\end{array}$ & Latitude & Longitude & $\begin{array}{l}\text { Land-surface } \\
\text { altitude } \\
\text { (ft above } \\
\text { NAVD29) }\end{array}$ & $\begin{array}{l}\text { Hole } \\
\text { depth } \\
\text { (ft bls) }\end{array}$ & $\begin{array}{l}\text { Perforated } \\
\text { interval(s) } \\
\text { (ft bls) }\end{array}$ & $\begin{array}{l}\text { Geologic formation } \\
\text { in which well is } \\
\text { completed }\end{array}$ \\
\hline 345603110450301 & ${ }^{1}$ Winslow T-Well & $34^{\circ} 56^{\prime} 03^{\prime \prime}$ & $-110^{\circ} 45^{\prime} 05^{\prime \prime}$ & 5,180 & 1,210 & $200-500$ & Coconino Sandstone \\
\hline 350002110355501 & ${ }^{1}$ Winslow I-40 Well & $35^{\circ} 00^{\prime} 02^{\prime \prime}$ & $-110^{\circ} 35^{\prime} 57^{\prime \prime}$ & 4,890 & 610 & $72-610$ & Coconino Sandstone \\
\hline 350706111014701 & Sunshine Well & $35^{\circ} 07^{\prime} 06^{\prime \prime}$ & $-111^{\circ} 01^{\prime} 50^{\prime \prime}$ & 5,352 & 1,155 & -- & Coconino Sandstone \\
\hline 345023110111401 & Holbrook BOR & $34^{\circ} 50^{\prime} 23^{\prime \prime}$ & $-110^{\circ} 11^{\prime} 16^{\prime \prime}$ & 5,360 & 570 & $310-570$ & Coconino Sandstone \\
\hline 342024109220301 & TEP M-6 & $34^{\circ} 20^{\prime} 24^{\prime \prime}$ & $-109^{\circ} 22^{\prime} 05^{\prime \prime}$ & 6,060 & 550 & $160-550$ & ${ }^{2}$ Coconino Sandstone \\
\hline 343637109374901 & Hunt Valley & $34^{\circ} 36^{\prime} 37^{\prime \prime}$ & $-109^{\circ} 37^{\prime} 51^{\prime \prime}$ & 5,430 & 410 & -- & Coconino Sandstone \\
\hline 344928109515301 & Petrified Forest Mesa & $34^{\circ} 49^{\prime} 28^{\prime \prime}$ & $-109^{\circ} 51 ’ 55^{\prime \prime}$ & 5,615 & 980 & $851-980$ & Coconino Sandstone \\
\hline 345310110062501 & AZ Cattle Company & $34^{\circ} 53^{\prime} 10^{\prime \prime}$ & $-110^{\circ} 06^{\prime} 27^{\prime \prime}$ & 5,165 & 285 & -- & Coconino Sandstone \\
\hline 345333109474501 & $\begin{array}{l}\text { Petrified Forest Agate } \\
\text { Bridge }\end{array}$ & $34^{\circ} 53^{\prime} 33^{\prime \prime}$ & $-109^{\circ} 47^{\prime} 47^{\prime \prime}$ & 5,590 & 780 & $690-780$ & Coconino Sandstone \\
\hline 350446110502501 & Tucker Mesa & $35^{\circ} 04^{\prime} 46^{\prime \prime}$ & $-110^{\circ} 50^{\prime} 27^{\prime \prime}$ & 5,140 & 650 & $301-650$ & Coconino Sandstone \\
\hline 350716111354401 & Lake Mary 1 & $35^{\circ} 07^{\prime} 16^{\prime \prime}$ & $-111^{\circ} 35^{\prime} 47^{\prime \prime}$ & 6,810 & 1,287 & $790-1140$ & Supai Formation \\
\hline 351025111303701 & NPS Walnut Canyon & $35^{\circ} 10^{\prime} 25^{\prime \prime}$ & $-111^{\circ} 30^{\prime} 40^{\prime \prime}$ & 6,710 & 2,007 & $1,493-2,007$ & Supai Formation \\
\hline 351213111274001 & ADOT Winona & $35^{\circ} 12^{\prime} 13^{\prime \prime}$ & $-111^{\circ} 27^{\prime} 43^{\prime \prime}$ & 6,440 & 1,800 & $1352-1800$ & Supai Formation \\
\hline 352214111324601 & NPS Sunset Crater & $35^{\circ} 22^{\prime} 07^{\prime \prime}$ & $-111^{\circ} 32^{\prime} 40^{\prime \prime}$ & 6,970 & 2,200 & -- & Supai Formation \\
\hline 353410111284001 & NPS Citadel & $35^{\circ} 34^{\prime} 12^{\prime \prime}$ & $-111^{\circ} 28^{\prime} 49^{\prime \prime}$ & 5,381 & 1,800 & $1,780-1,788$ & Supai Formation \\
\hline 354646111294801 & Black Mesa Pipeline & $35^{\circ} 46^{\prime} 46^{\prime \prime}$ & $-111^{\circ} 29^{\prime} 51^{\prime \prime}$ & 4,830 & 1,292 & $1,072-1,292$ & Supai Formation \\
\hline 350848111381701 & Skunk Canyon & $35^{\circ} 08^{\prime} 48^{\prime \prime}$ & $-111^{\circ} 38^{\prime} 20^{\prime \prime}$ & 6,915 & 1,800 & $988-1788$ & Supai Formation \\
\hline 350856111441601 & Woody Mountain 5 & $35^{\circ} 08^{\prime} 56^{\prime \prime}$ & $-111^{\circ} 44^{\prime} 19^{\prime \prime}$ & 7,186 & 1,600 & $1288-1600$ & Coconino Sandstone \\
\hline 351127111360001 & Foxglenn & $35^{\circ} 11^{\prime} 37^{\prime \prime}$ & $-111^{\circ} 35^{\prime} 51^{\prime \prime}$ & 6,775 & 2,280 & $1,145-2,280$ & Supai Formation \\
\hline 351223111342802 & Continental 2 & $35^{\circ} 12^{\prime} 24^{\prime \prime}$ & $-111^{\circ} 34^{\prime} 29^{\prime \prime}$ & 6,750 & 2,160 & -- & Supai Formation \\
\hline 350828111391501 & Flagstaff Airport Well & $35^{\circ} 08^{\prime} 28^{\prime \prime}$ & $-111^{\circ} 39^{\prime} 18^{\prime \prime}$ & 6,960 & 1,590 & $40-1,590$ & ${ }^{3}$ Coconino Sandstone \\
\hline \multicolumn{8}{|c|}{ Site 1} \\
\hline 351022111061801 & $10 \mathrm{~W}-1$ & $35^{\circ} 10^{\prime} 22^{\prime \prime}$ & $-111^{\circ} 06^{\prime} 21^{\prime \prime}$ & 5,378 & 1,180 & $686-1,087$ & ${ }^{4}$ Coconino Sandstone \\
\hline 351023111062002 & PW-1A & $35^{\circ} 10^{\prime} 23^{\prime \prime}$ & $-111^{\circ} 06^{\prime} 23^{\prime \prime}$ & 5,378 & 1,134 & $837-1,077$ & ${ }^{4}$ Coconino Sandstone \\
\hline \multicolumn{8}{|c|}{ Site 2} \\
\hline 351214111022101 & $1 \mathrm{OW}-2 \mathrm{~B}$ & $35^{\circ} 12^{\prime} 14^{\prime \prime}$ & $-111^{\circ} 02^{\prime} 24^{\prime \prime}$ & 5,030 & 1,069 & -- & Coconino Sandstone \\
\hline 351216111021902 & OW-2A shallow & $35^{\circ} 12^{\prime} 16^{\prime \prime}$ & $-111^{\circ} 02^{\prime} 19^{\prime \prime}$ & 4,985 & 1,140 & $400-420$ & Coconino Sandstone \\
\hline 351216111021903 & OW-2A middle & $35^{\circ} 12^{\prime} 16^{\prime \prime}$ & $-111^{\circ} 02^{\prime} 19^{\prime \prime}$ & 4,985 & 1,140 & $661-681$ & Coconino Sandstone \\
\hline 351216111021904 & OW-2A deep & $35^{\circ} 12^{\prime} 16^{\prime \prime}$ & $-111^{\circ} 02^{\prime} 19^{\prime \prime}$ & 4,985 & 1,140 & $1,100-1,120$ & Supai Formation \\
\hline 351218111021701 & PW-2A & $35^{\circ} 12^{\prime} 18^{\prime \prime}$ & $-111^{\circ} 02^{\prime} 17^{\prime \prime}$ & 5021 & 1096 & $55-500$ & Supai Formation \\
\hline 351213111022101 & PW-2B & $35^{\circ} 12^{\prime} 13^{\prime \prime}$ & $-111^{\circ} 02^{\prime} 24^{\prime \prime}$ & 5030 & 1095 & $577-997$ & Coconino Sandstone \\
\hline \multicolumn{8}{|c|}{ Site 3} \\
\hline 350959110562303 & 1OW-3A shallow & $35^{\circ} 09^{\prime} 59^{\prime \prime}$ & $-110^{\circ} 56^{\prime} 26^{\prime \prime}$ & 4,882 & 755 & $250-270$ & Coconino Sandstone \\
\hline 350959110562302 & OW-3A deep & $35^{\circ} 09^{\prime} 57^{\prime \prime}$ & $-110^{\circ} 56^{\prime} 23^{\prime \prime}$ & 4,882 & 755 & 694-714 & Coconino Sandstone \\
\hline 350956110562002 & OW-3C shallow & $35^{\circ} 09^{\prime} 56^{\prime \prime}$ & $-110^{\circ} 56^{\prime} 20^{\prime \prime}$ & 4,881 & 1,180 & $240-260$ & Coconino Sandstone \\
\hline 350956110562003 & OW-3C middle & $35^{\circ} 09^{\prime} 57^{\prime \prime}$ & $-110^{\circ} 56^{\prime} 21^{\prime \prime}$ & 4,881 & 1,180 & $680-700$ & Coconino Sandstone \\
\hline 350956110562004 & OW-3C deep & $35^{\circ} 09^{\prime} 56^{\prime \prime}$ & $-110^{\circ} 56^{\prime} 20^{\prime \prime}$ & 4,881 & 1,180 & $1,150-1,170$ & Supai Formation \\
\hline 350957110562601 & PW-3 & $35^{\circ} 09^{\prime} 56^{\prime \prime}$ & $-110^{\circ} 56^{\prime} 26^{\prime \prime}$ & 4,881 & 1,128 & $696-1,076$ & ${ }^{4}$ Coconino Sandstone \\
\hline
\end{tabular}

${ }^{1}$ Continuously monitored sites.

${ }^{2}$ Coconino Sandstone overlain by Kaibab Limestone.

${ }^{3}$ Coconino Sandstone overlain by Kaibab Limestone and Toroweap Formation.

${ }^{4}$ Interfingered Coconino Sandstone and Schnebly Hill Formation. 

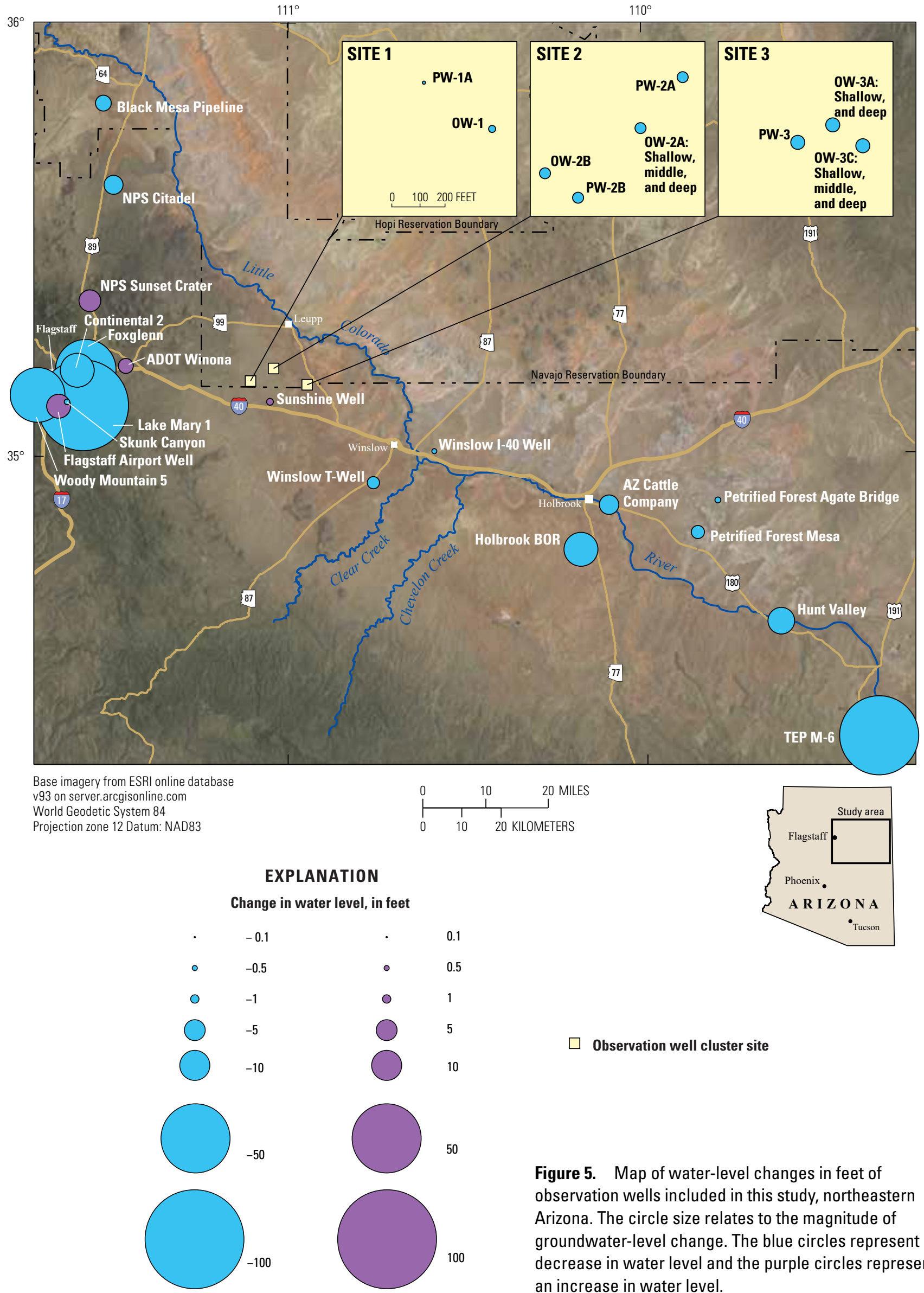

50

Figure 5. Map of water-level changes in feet of observation wells included in this study, northeastern Arizona. The circle size relates to the magnitude of groundwater-level change. The blue circles represent a decrease in water level and the purple circles represent an increase in water level. 

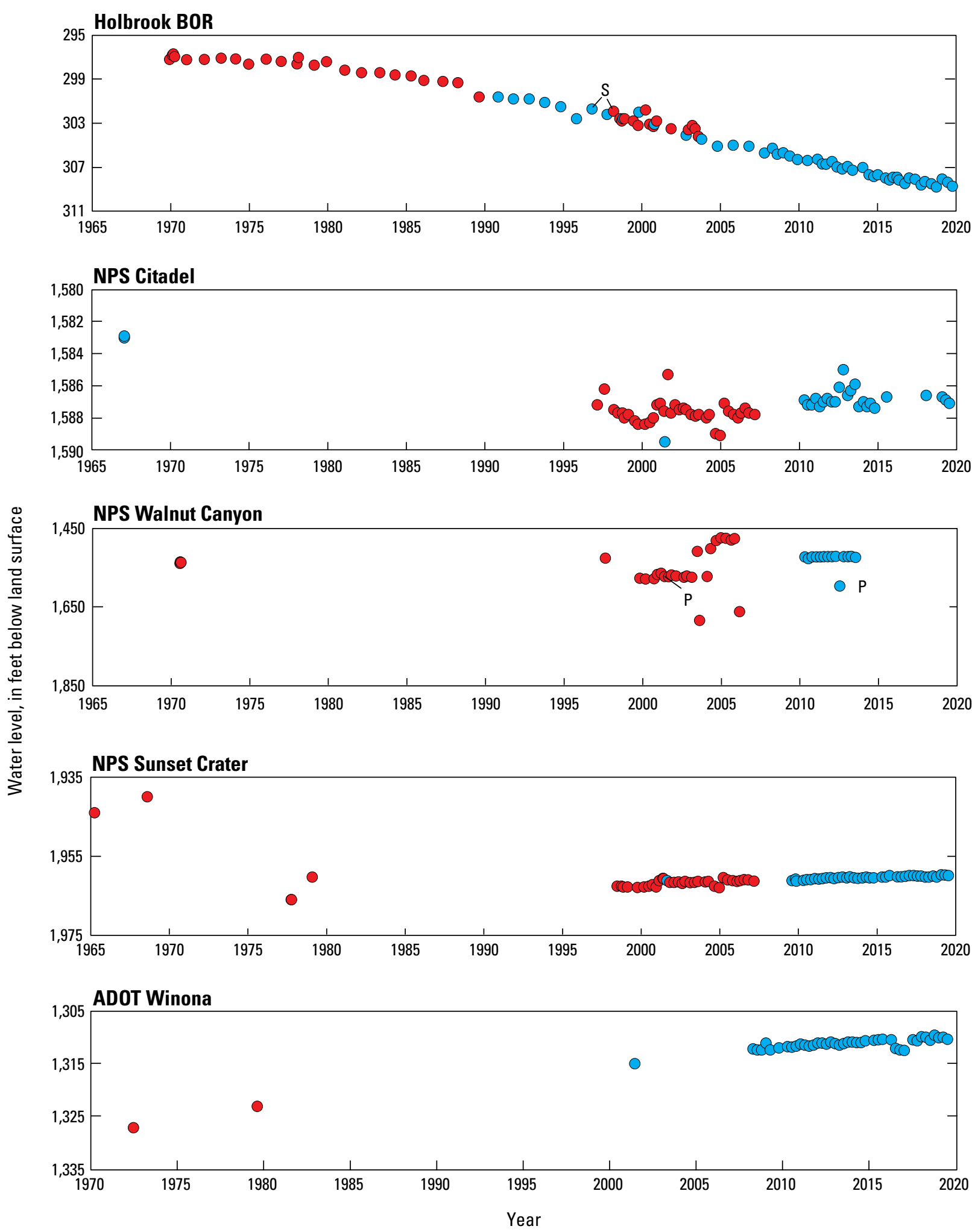

\section{EXPLANATION}

Measuring agency

- Arizona Department of Water and Recreation

- U.S. Geological Survey
Figure 6. Graph of measured water levels (1965-2020 or 1970-2020) in wells no longer in the observation-well network, $\mathrm{C}$ aquifer, northeastern Arizona. " $P$ " indicates the site well was being pumped during the measurement. " $S$ " indicates a nearby well being pumped. 

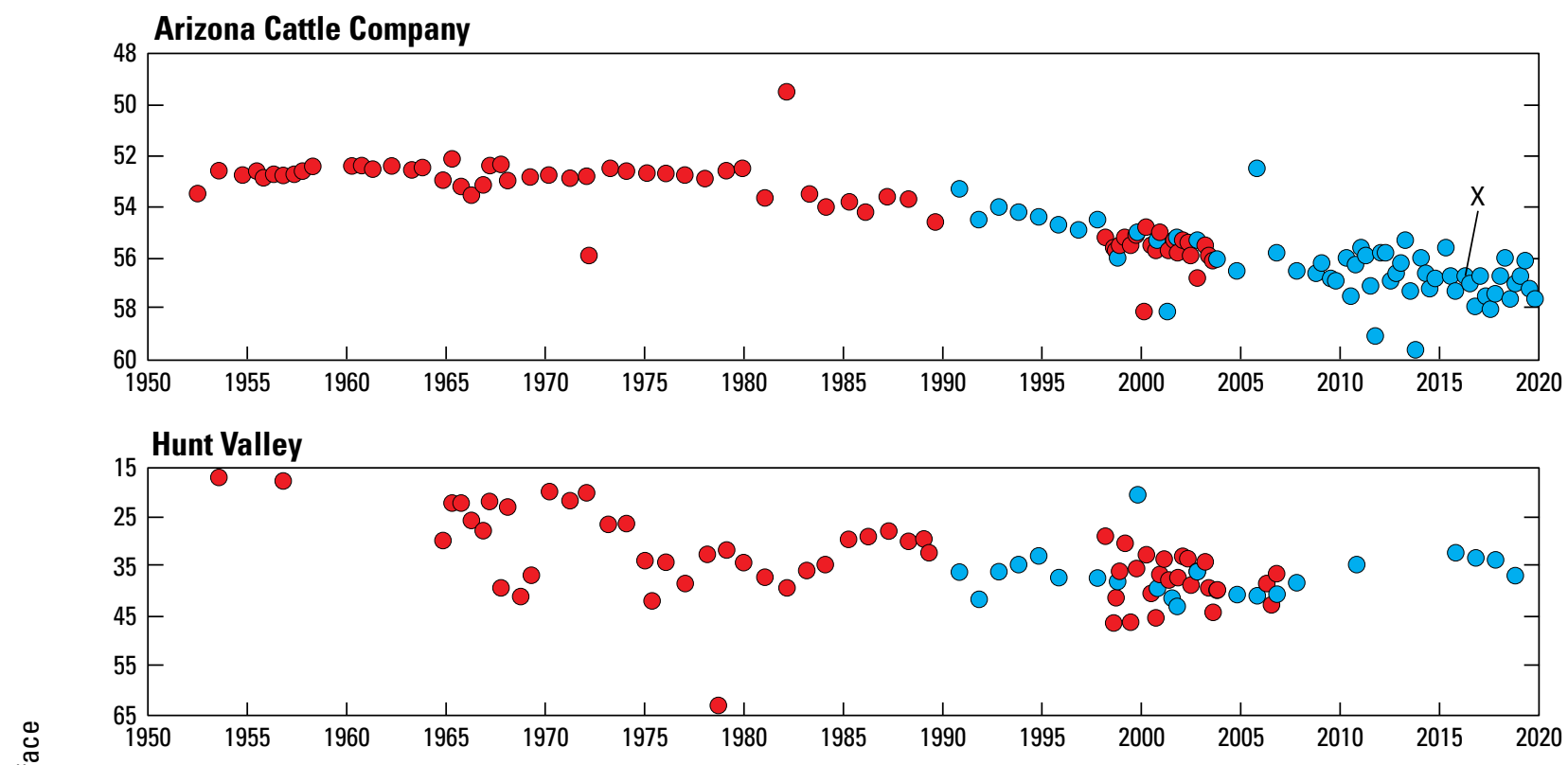

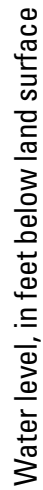

Woody Mountain 5
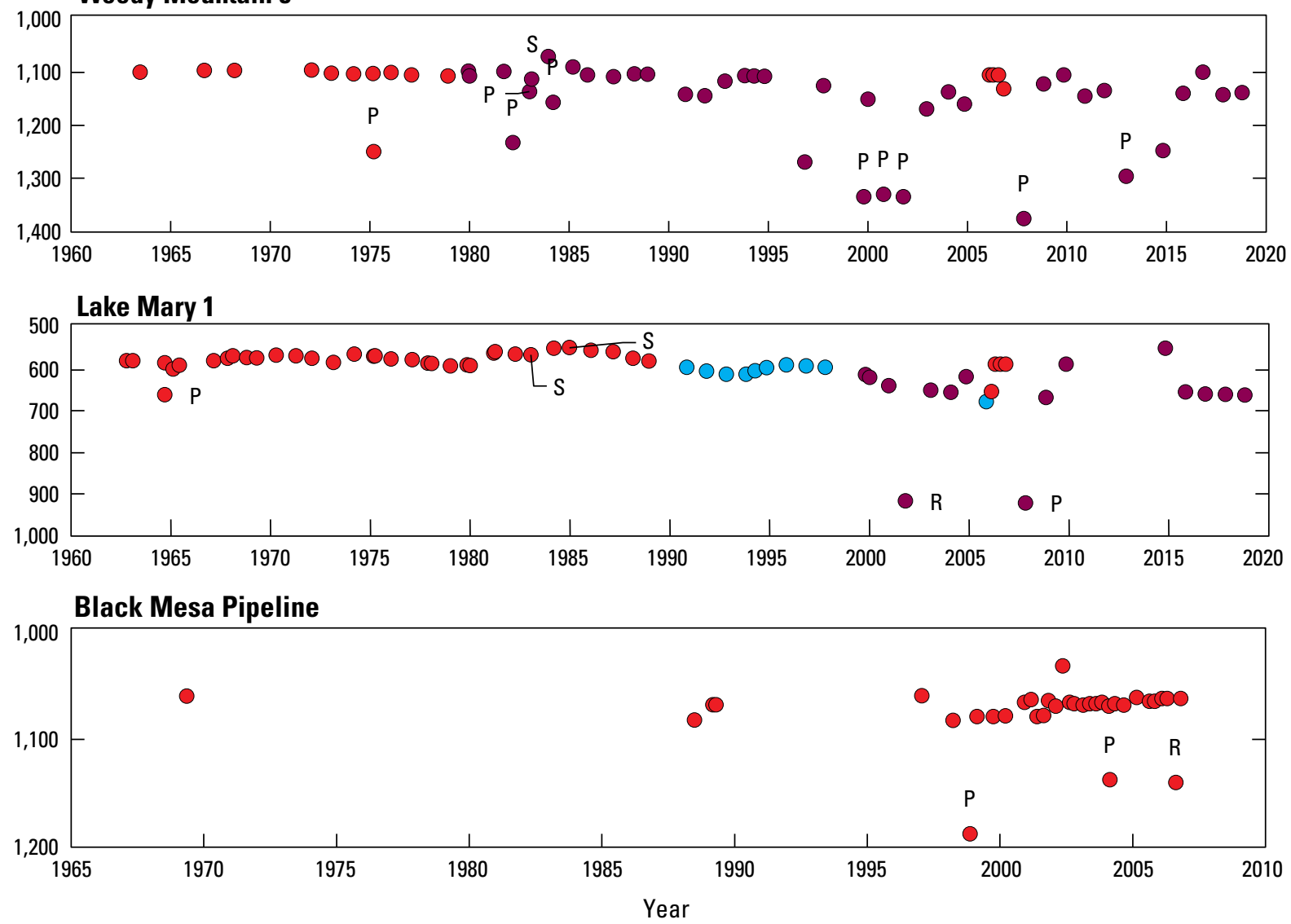

\section{EXPLANATION}

Measuring agency

- Arizona Department of Water and Recreation

- Owner

- U.S. Geological Survey
Figure 7. Graph of measured water levels (1950-2020, 1960-2020, or 1965-2020) in wells no longer in the observation-well network, $C$ aquifer, northeastern Arizona. " $\mathrm{S}$ " indicates a nearby well being pumped, " $\mathrm{P}$ " indicates the site well was being pumped, " $X$ " indicates surface water effects during the measurement, and " $R$ " indicates the well was recently pumped. 

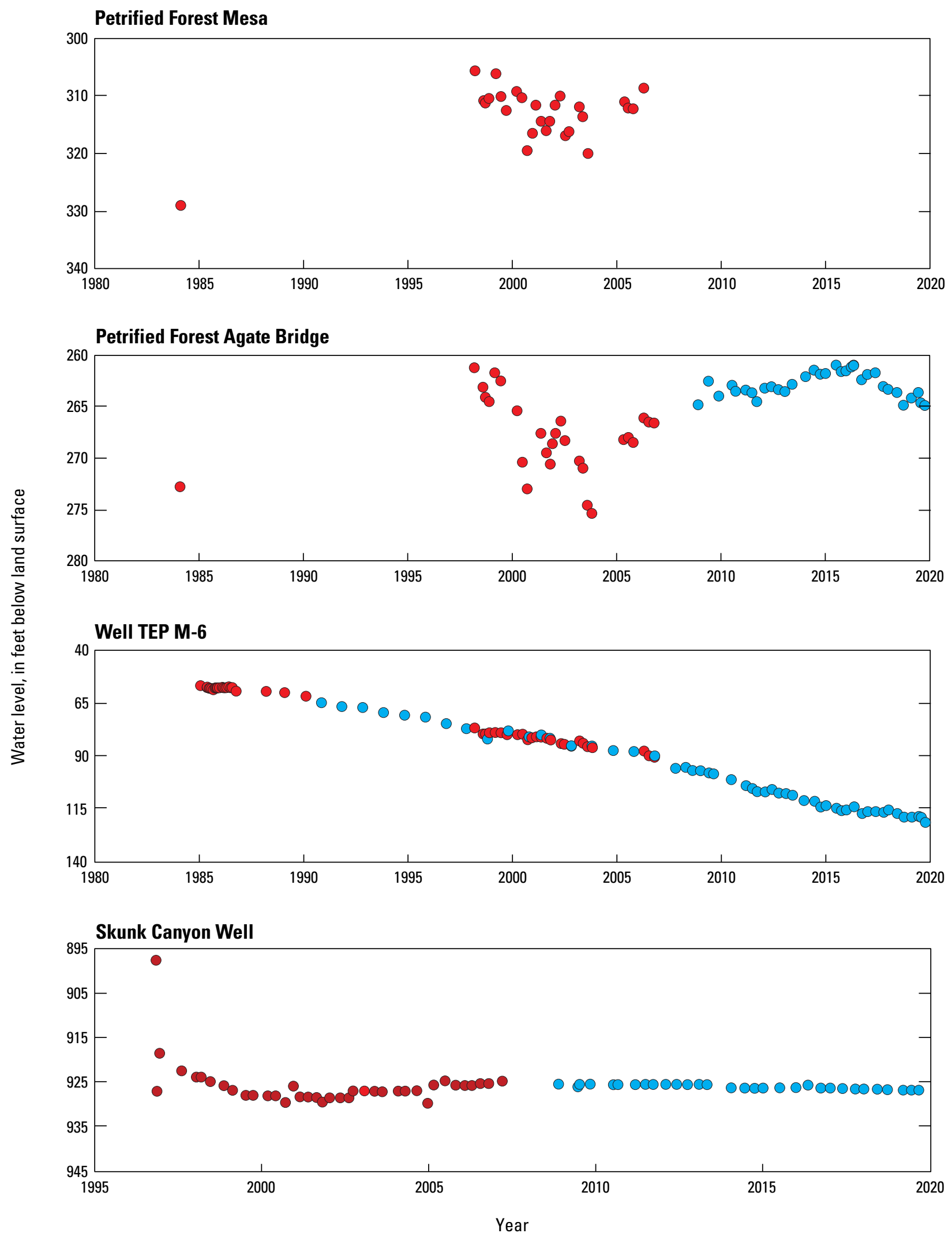

\section{EXPLANATION}

Measuring agency

- Arizona Department of Water and Recreation

- U.S. Geological Survey
Figure 8. Graph of measured water levels (1980-2020 or 1995-2020) in wells no longer in the observation-well network, $\mathrm{C}$ aquifer, northeastern Arizona. For wells with two measuring agencies, City of Flagstaff data is in red, and Arizona Department of Water and Recreation (ADWR) data is in blue. 

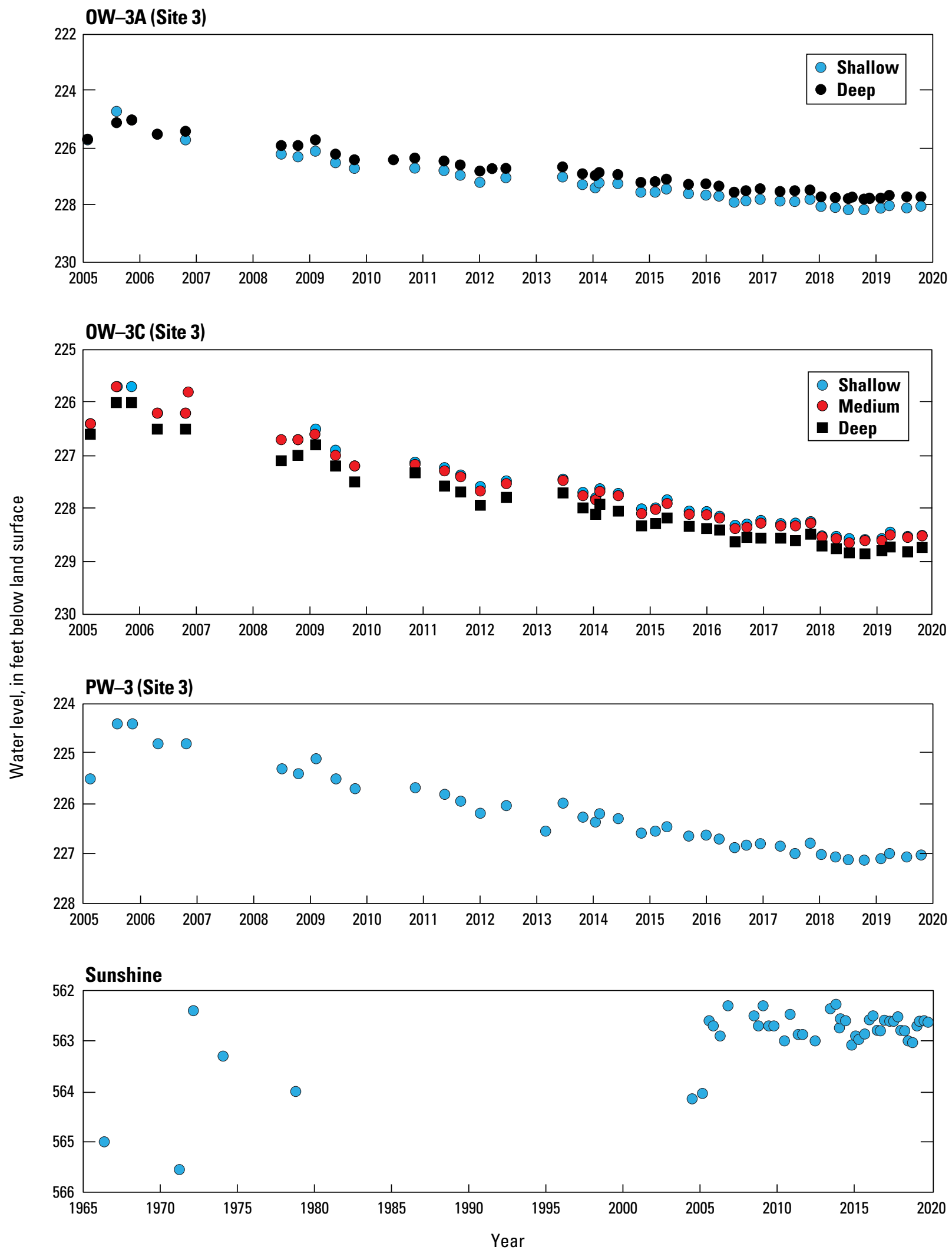

Figure 9. Graph of measured water levels (2005-2020 or 1965-2020) in wells no longer in the observation-well network, $\mathrm{C}$ aquifer, northeastern Arizona. 

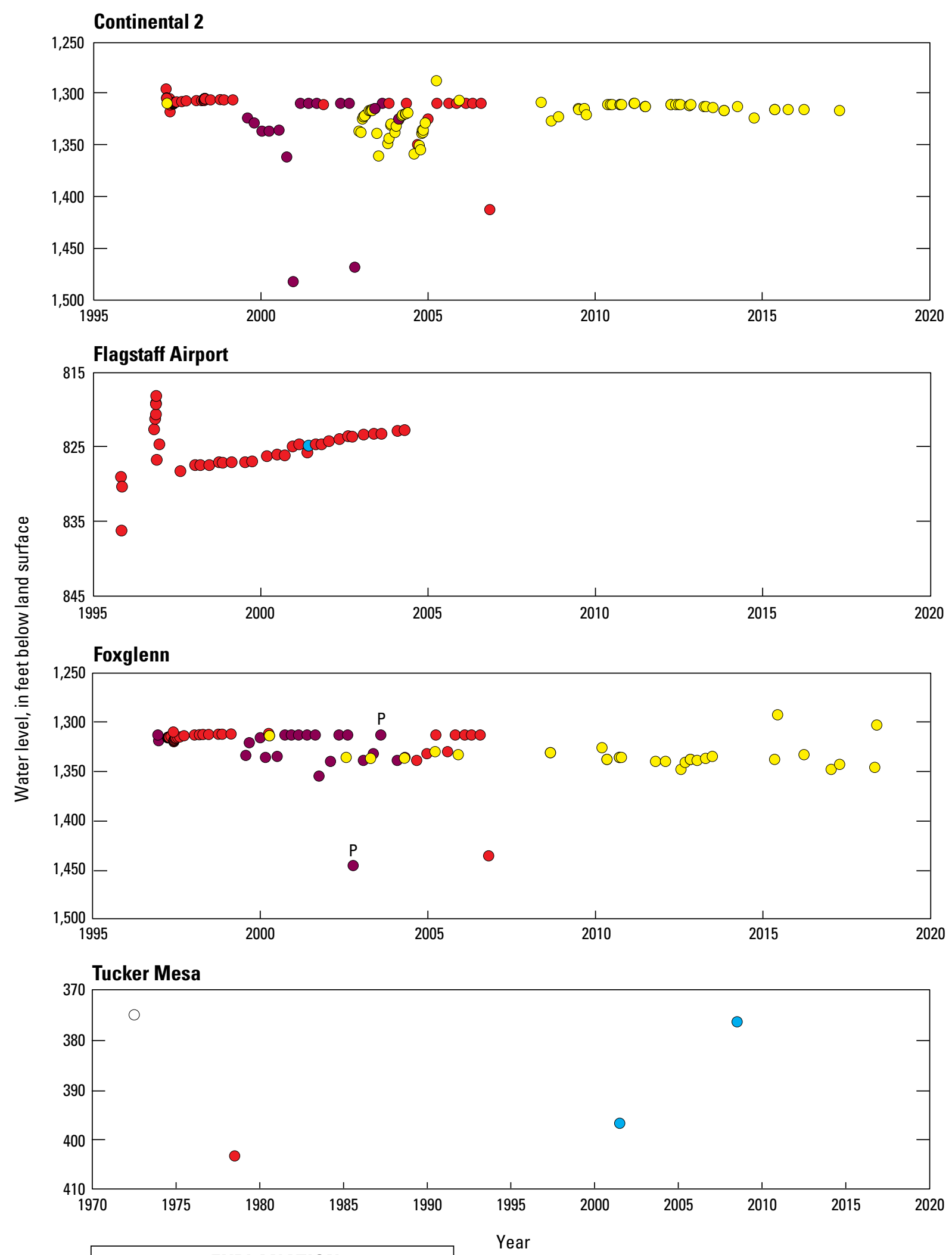

Measuring Agency

- Arizona Department of Water and Recreation

- City of Flagstaff

- Owner

○ Unknown

- U.S. Geological Survey

Figure 10. Graph of measured water levels (1965-2020 or 1975-2020) in the observation-well network, C aquifer, northeastern Arizona. 


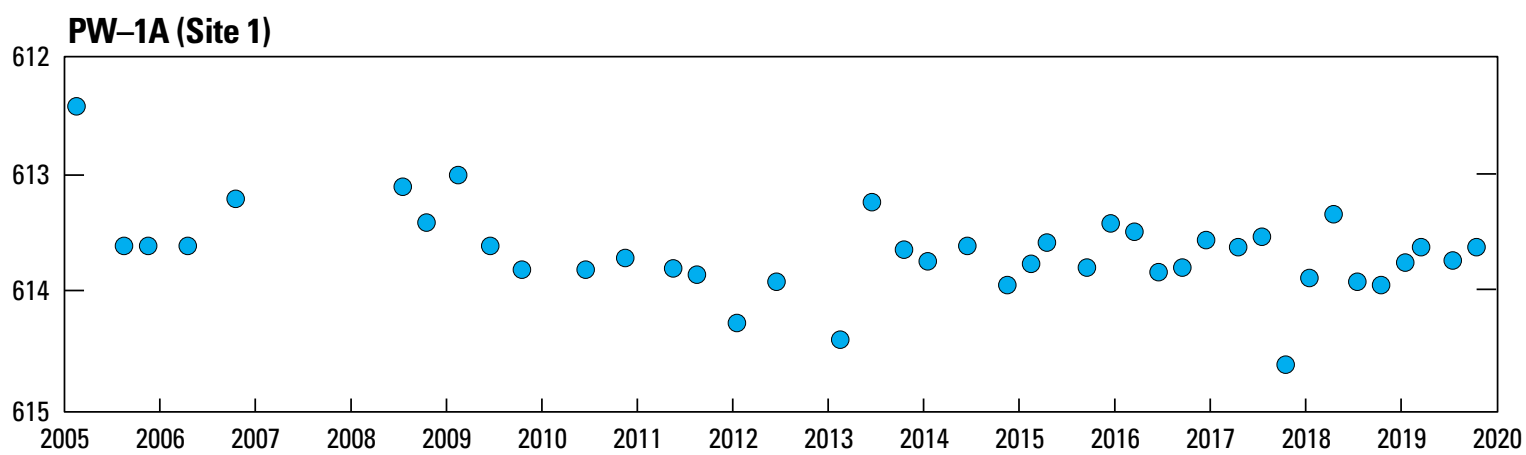

OW-2A (Site 2)

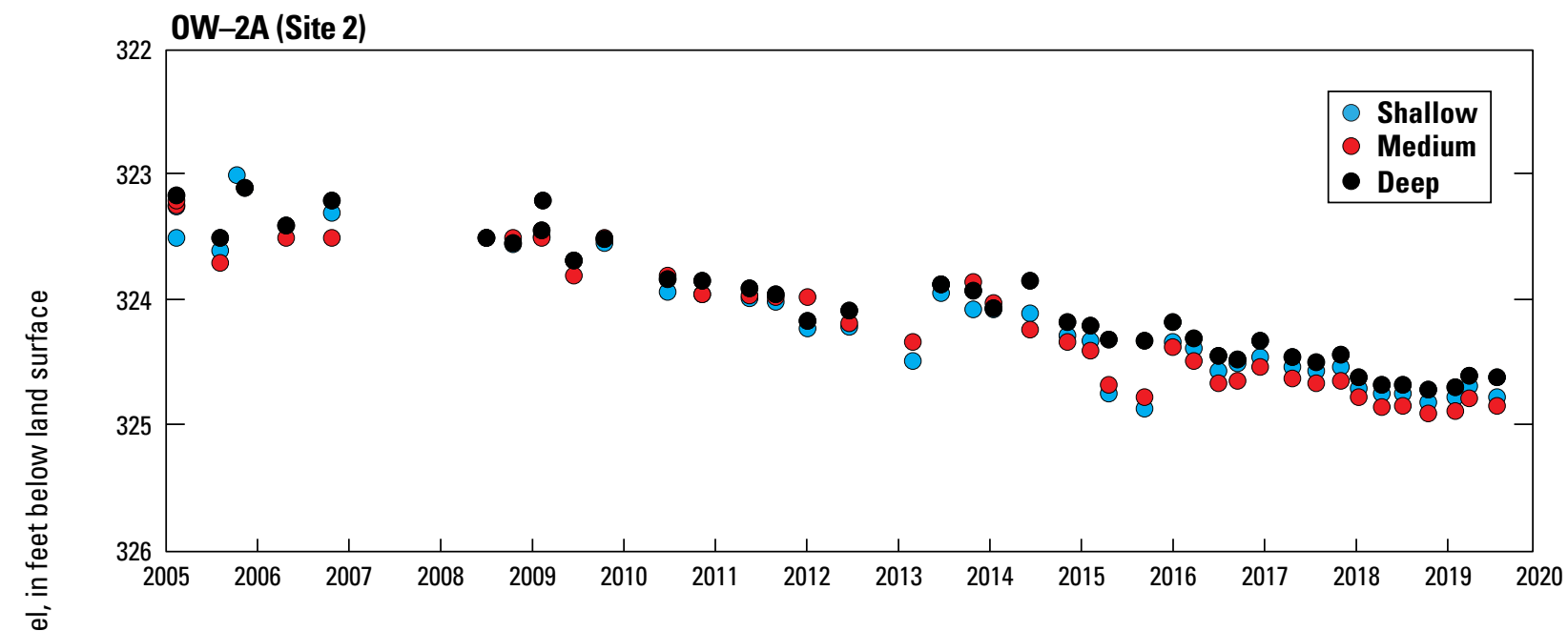

PW-2A (Site 2)
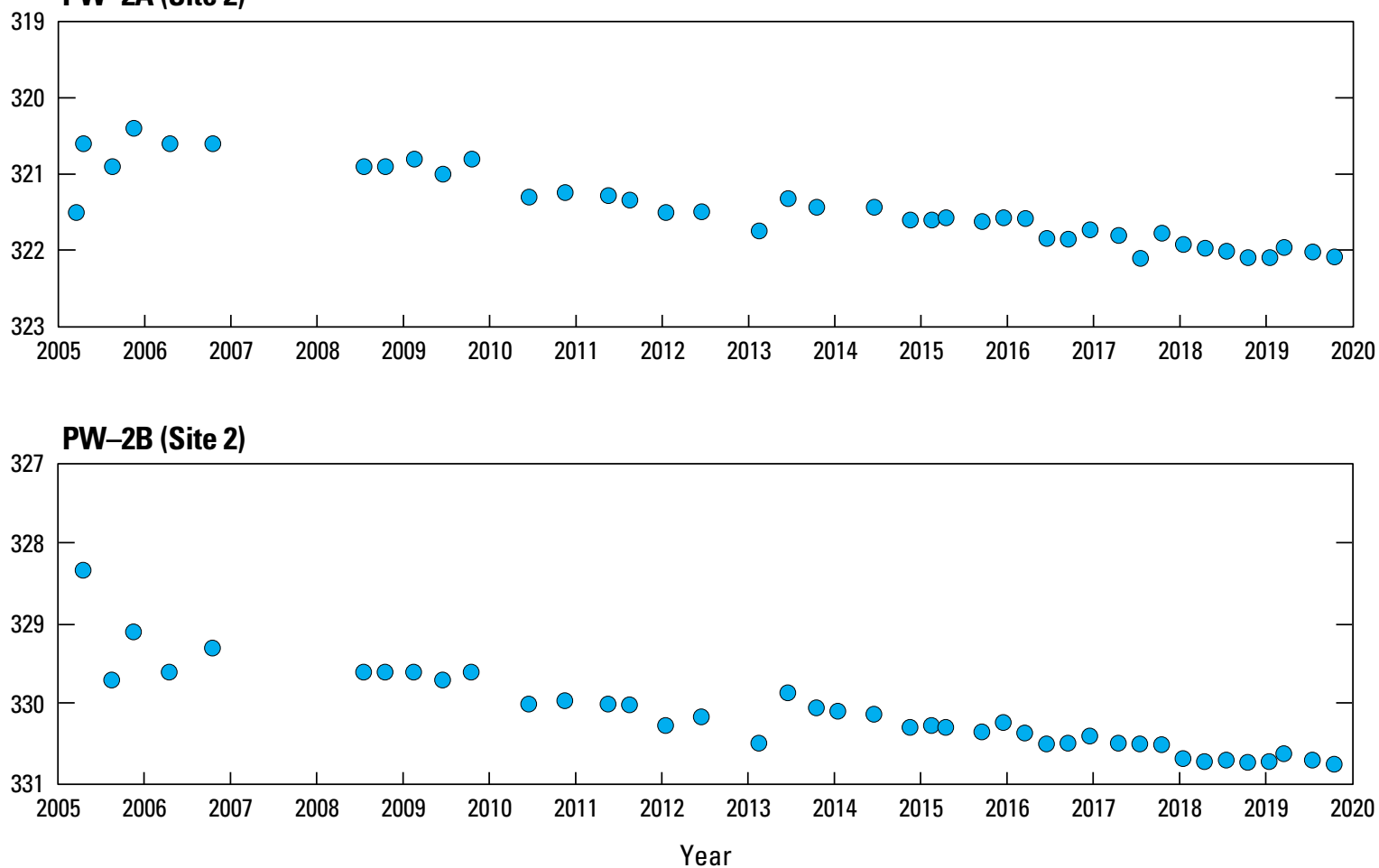

Figure 11. Graph of measured water levels (2005-2020) in the observation-well network, C aquifer, northeastern Arizona. 
Table 2. Water level changes for the period of record for each well. Water level changes were calculated using only measurements from 0 ctober through January and within two standard deviations in order to minimize the effect of seasonal variability and outlier data.

[ft, feet; dashes, sufficient information not available; WY, water year]

\begin{tabular}{|c|c|c|c|c|}
\hline $\begin{array}{l}\text { U.S. Geological Survey } \\
\text { identification number }\end{array}$ & $\begin{array}{c}\text { Bureau of Reclamation } \\
\text { designation or common name }\end{array}$ & $\begin{array}{c}\text { Date of first measurement } \\
\text { used in analysis }\end{array}$ & $\begin{array}{c}\text { Date of last measurement } \\
\text { used in analysis }\end{array}$ & $\begin{array}{l}\text { Change in water levels } \\
\text { for period of record (ft) }\end{array}$ \\
\hline 345603110450301 & Winslow T-Well & $1 / 7 / 1970$ & $1 / 31 / 2019$ & -1.63 \\
\hline 350706111014701 & ${ }^{1}$ Sunshine Well & $1 / 28 / 1974$ & $1 / 31 / 2019$ & 0.60 \\
\hline 345023110111401 & Holbrook BOR & $12 / 2 / 1969$ & $10 / 1 / 2018$ & -11.61 \\
\hline 343637109374901 & ${ }^{2}$ Hunt Valley & $11 / 5 / 1964$ & $10 / 23 / 2018$ & -7.10 \\
\hline 344928109515301 & Petrified Forest Mesa & $11 / 25 / 1998$ & $10 / 17 / 2005$ & -1.80 \\
\hline 345310110062501 & AZ Cattle Company & $10 / 9 / 1954$ & $1 / 28 / 2019$ & -3.95 \\
\hline 345333109474501 & ${ }^{1}$ Petrified Forest Agate Bridge & $11 / 25 / 1998$ & $10 / 1 / 2018$ & -0.36 \\
\hline 351213111274001 & ADOT Winona & $10 / 15 / 2008$ & $1 / 31 / 2019$ & 2.30 \\
\hline 352214111324601 & NPS Sunset Crater & $10 / 7 / 1977$ & $1 / 31 / 2019$ & 6.30 \\
\hline 353410111284001 & NPS Citadel & $1 / 23 / 1967$ & $1 / 31 / 2019$ & -3.70 \\
\hline 354646111294801 & Black Mesa Pipeline & $1 / 21 / 1997$ & $10 / 24 / 2006$ & -2.60 \\
\hline 350848111381701 & ${ }^{1}$ Skunk Canyon & $11 / 11 / 1996$ & $1 / 4 / 2018$ & 0.00 \\
\hline 350856111441601 & Woody Mountain 5 & $1 / 25 / 1972$ & $10 / 19 / 2018$ & -41.60 \\
\hline 351127111360001 & Foxglenn & $12 / 12 / 1996$ & $1 / 12 / 2017$ & -35.00 \\
\hline 351223111342802 & Continental 2 & $1 / 15 / 1998$ & $10 / 29 / 2016$ & -9.80 \\
\hline 351216111021902 & OW-2A shallow & $10 / 23 / 2006$ & $1 / 31 / 2019$ & -1.47 \\
\hline 351216111021903 & OW-2A middle & $10 / 23 / 2006$ & $1 / 31 / 2019$ & -1.38 \\
\hline 351216111021904 & OW-2A deep & $11 / 10 / 2005$ & $1 / 31 / 2019$ & -1.59 \\
\hline 351218111021701 & PW-2A & $10 / 23 / 2006$ & $1 / 31 / 2019$ & -1.49 \\
\hline 351213111022101 & PW-2B & $10 / 23 / 2006$ & $1 / 31 / 2019$ & -1.42 \\
\hline \multicolumn{5}{|c|}{ Site 3} \\
\hline 350959110562303 & OW-3A shallow & $1 / 29 / 2005$ & $1 / 31 / 2019$ & -2.07 \\
\hline 350959110562302 & OW-3A deep & $1 / 29 / 2005$ & $1 / 31 / 2019$ & -2.40 \\
\hline 350956110562002 & OW-3C shallow & $10 / 23 / 2006$ & $1 / 31 / 2019$ & -2.37 \\
\hline 350956110562003 & OW-3C middle & $10 / 23 / 2006$ & $1 / 31 / 2019$ & -2.41 \\
\hline 350956110562004 & OW-3C deep & $10 / 16 / 2008$ & $1 / 31 / 2019$ & -1.80 \\
\hline 350957110562601 & PW-3 & $10 / 23 / 2006$ & $1 / 31 / 2019$ & -2.30 \\
\hline
\end{tabular}

'No available data for WY-2012 within criteria.

${ }^{2}$ No available data for WY 2012-15 within criteria; WY 2011 used for analysis.

'No available data for WY 2011-15 within criteria; WY 2010 used for analysis. 
These three well-cluster sites were drilled between January and April 2005. The well clusters are near a proposed site of a $\mathrm{C}$-aquifer production well field and were intended to provide information for characterizing hydrogeologic properties of the $\mathrm{C}$ aquifer in that area (Hoffmann and others, 2006).

In addition to the quarterly water-level measurements, five of the wells in the C-Aquifer Monitoring Program are equipped with continuously-logging pressure transducers that collect water-level data at 15-min intervals (figs. 12-14). One well per well-cluster site is continuously monitored: Well OW-1 for Site 1, Well OW-2B for Site 2, and Well OW-3A shallow for Site 3. The Winslow T-Well and Winslow I-40 Well are the other two continuously monitored wells. With continuous data, it is possible to see overarching trends in the aquifer.

In order to minimize the effect of potential seasonal variability and outlier data, only water level measurements from October through January that are within two standard deviations of the mean are used in any water-level

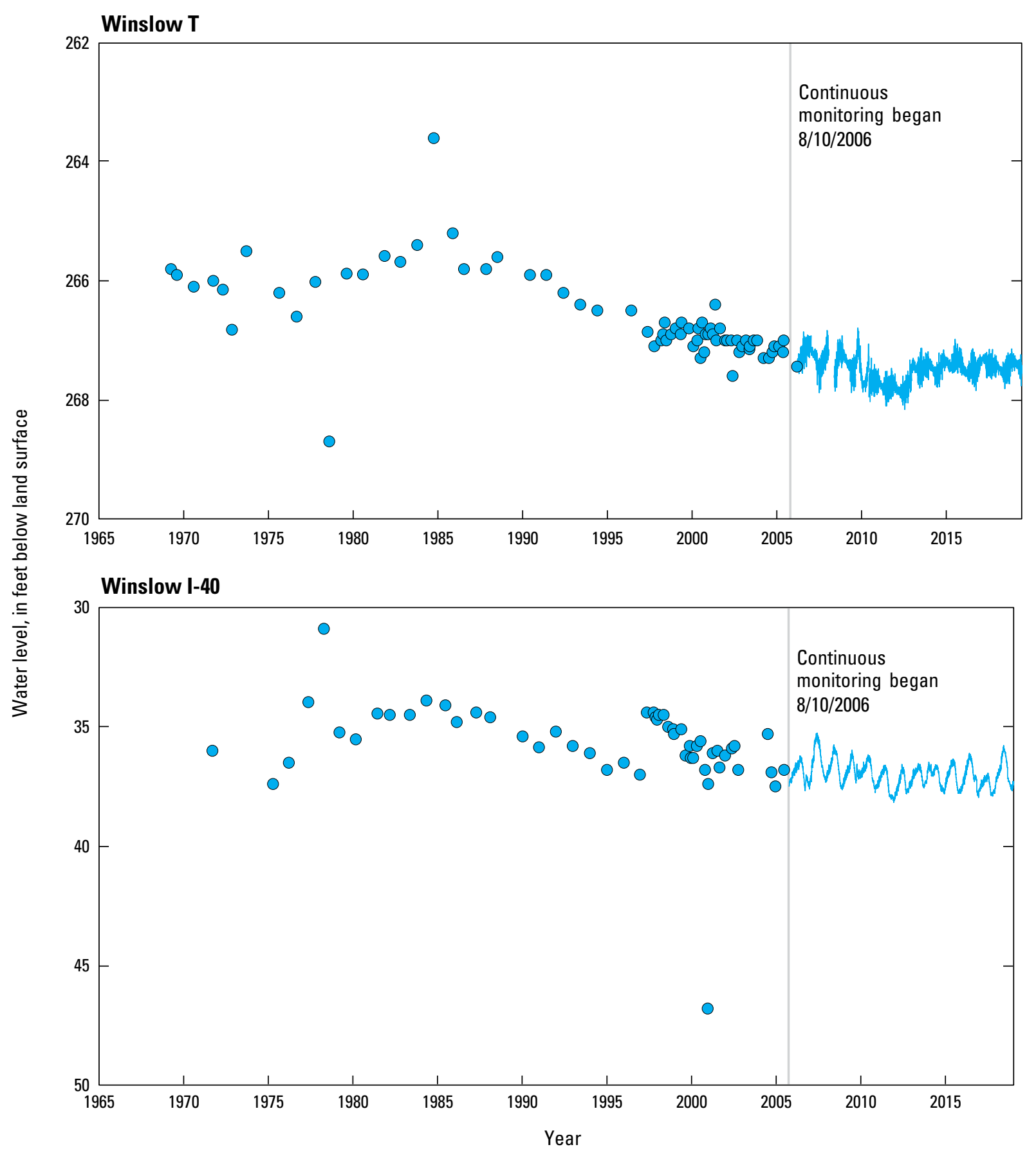

Figure 12. Graph of measured and continuously recorded water levels (1965-2020) in the observation-well network, $\mathrm{C}$ aquifer, northeastern Arizona. See figure 13 for a detailed view of the continuously monitored period. 

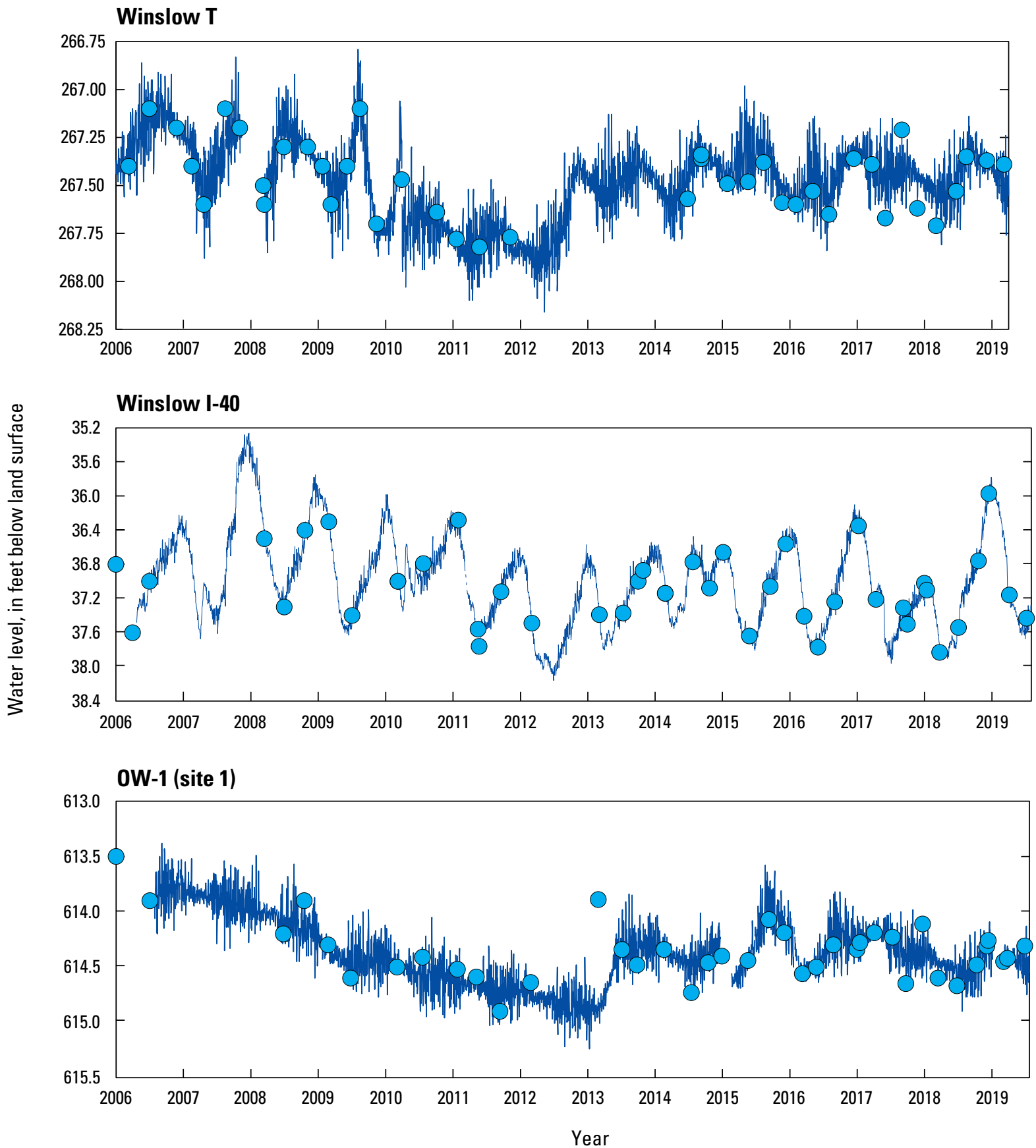

Figure 13. Graph of measured and continuously recorded water levels (2006-2020) in the observationwell network, C aquifer, northeastern Arizona. Dots represent manual measurements; the blue line represents data from the continuously-logging pressure transducer.

comparisons (table 2). The October-to-January period was chosen for analysis based on the potential for surface-water runoff and (or) increased pumping to influence water levels during the spring and summer months. Infiltration from surface water from summer monsoon events and spring snowmelt have the potential to influence wells in the network.
Higher rates of pumping that could influence observation wells through drawdown are also more common in summer months.

Using these data, it is possible to see changes in the water levels for the five continuously monitored wells (figs. 12-14). Two of the continuously monitored wells (Well OW-2B and Well OW-3A shallow) show a steady decrease in water levels 


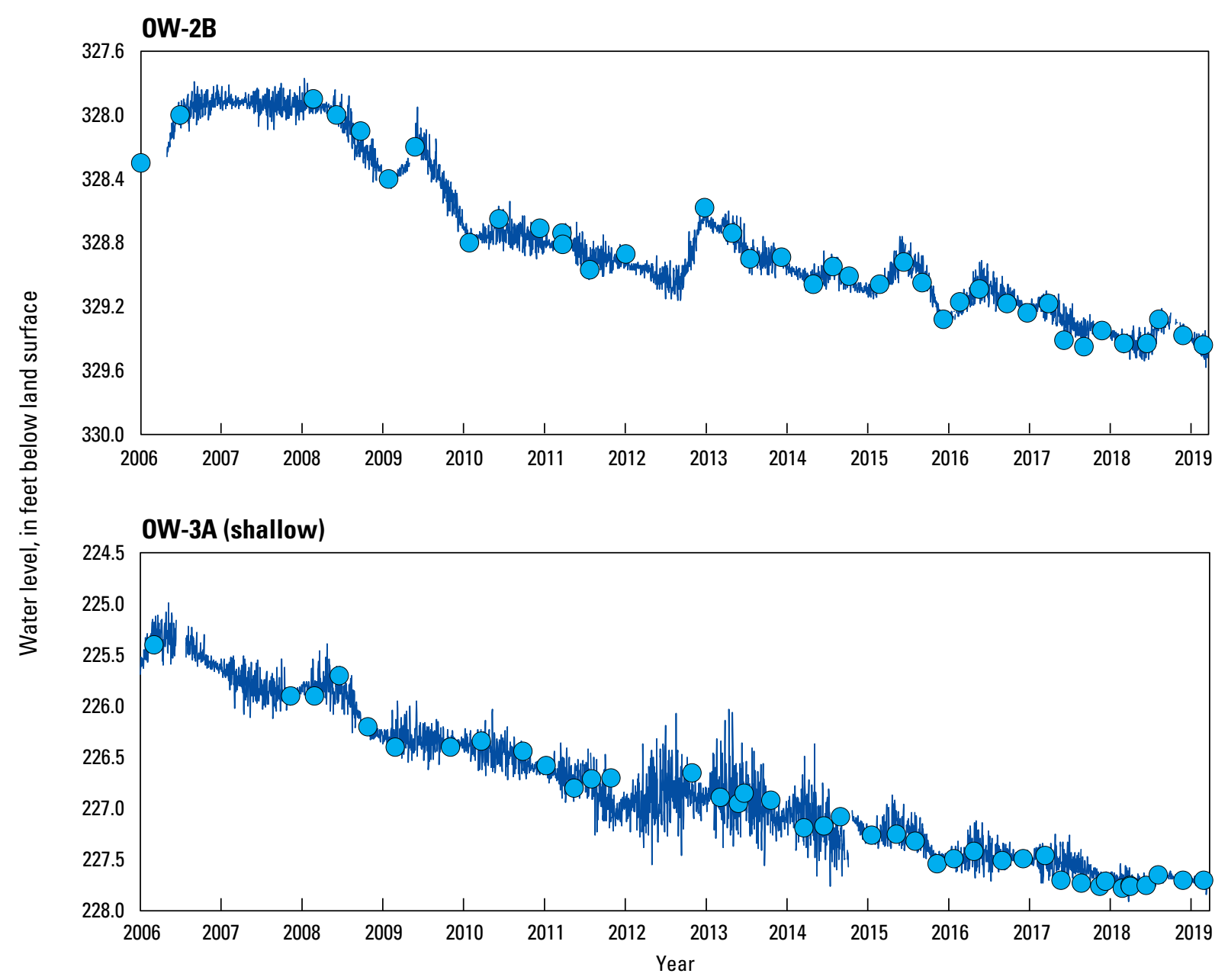

Figure 14. Graph of measured and continuously recorded water levels (2006-2020) in the observation-well network, $C$ aquifer, northeastern Arizona. Dots represent manual measurements; the blue line represents data from the continuously-logging pressure transducer.

since monitoring began in 2006. Water levels in Well OW-2B and Well OW-3A shallow ranged from $328.00 \mathrm{ft}$ bls to 329.43 $\mathrm{ft}$ bls and $225.68 \mathrm{ft}$ bls to $227.75 \mathrm{ft}$ bls, respectively (table 2). Water levels for the Winslow T-Well have decreased by $1.63 \mathrm{ft}$ since 1970 (fig. 12). Water levels for the Winslow I-40 Well have decreased by $0.26 \mathrm{ft}$ since 1972 (fig. 12). Of the five continuously monitored wells, water level measurements for the end of WY 2019 range from $37.16 \mathrm{ft}$ bls at the Winslow I-40 Well to $614.42 \mathrm{ft}$ bls at Well OW-1.

Although all wells in the well clusters were drilled in 2006, the period of groundwater-level record varies for other wells. Water levels have decreased in certain wells around Flagstaff, a major pumping center (fig. 5; table 2). This decrease can be seen in Lake Mary 1 Well, Foxglenn Well, and Woody Mountain 5 Well. Lake Mary 1 Well has seen the largest water-level decrease of any of the wells near Flagstaff (figs. 6-9). Since the first measurement used for analysis in 1962, Lake Mary 1 Well has experienced a water-level decrease of $81.20 \mathrm{ft}$ (fig. 7). Not all wells centered around Flagstaff show decreasing water levels. NPS Walnut Canyon Well, Flagstaff Airport Well, Sunset Crater Well, and ADOT Winona Well show an increase in water levels (fig. 6 and 9; table 2). The largest increase can be seen in NPS Walnut Canyon Well, with a water-level increase of $55.0 \mathrm{ft}$ since the first measurement used for analysis in 1999 (fig. 6; table 2). Water-level observations for this well, however, are highly variable with a large standard deviation of 44.41. Other wells around Flagstaff, such as Skunk Canyon Well, show little change in water levels during their entire period of record (fig. 8). 
In the easterly extent of the $\mathrm{C}$ aquifer, wells show a decrease in water levels of varying degrees of magnitude. TEP M-6 Well and Holbrook BOR Well show the largest decrease in water levels for the wells located in the eastern extent of the $\mathrm{C}$ aquifer. Water levels in the TEP M-6 Well have decreased $62.09 \mathrm{ft}$ since 1985 (fig. 8). Water levels in Holbrook BOR Well have decreased by $11.61 \mathrm{ft}$ since the first measurement in 1969 (fig. 6).

\section{Surface-Water Discharge}

Surface-water discharge data can show the response of a stream reach to runoff produced by precipitation or snowmelt. Furthermore, surface-water discharge conditions during periods without overland runoff can provide information on baseflow. Baseflow is that portion of surface flow in a stream that comes solely from groundwater discharge. Baseflow of streams can vary spatially and temporally. Streams may exhibit gaining reaches, where streams gain flow from groundwater discharge, and (or) losing reaches, where stream flow re-enters the subsurface. Determining gaining and losing reaches of a groundwaterfed stream and how these characteristics change temporally can be indicative of changing water levels within the source aquifer (Alley and others, 1999). Because the surface-water discharge through the perennial reaches of Clear Creek and Chevelon Creek are fed by groundwater, surface-water discharge data can indicate trends in baseflow. Streamflow data were measured by streamflow-gaging stations and discrete baseflow investigations.

Three streamflow-gaging stations were in operation in the study area: two on Clear Creek and one on Chevelon Creek (table 3). All gages are currently discontinued. The data from all three gages beginning in 2005 were summarized by Brown and Macy (2012).

The USGS conducted a total of nine baseflow investigations, sometimes referred to as seepage runs, of varying extent between 2005 and 2019 along Clear Creek, Chevelon Creek, and the reach of the Little Colorado River between the confluences of the two tributaries. Baseflow was measured at multiple locations along the streams in as short a time as possible, with the intent of developing a detailed snapshot regarding the locations and amounts of $\mathrm{C}$-aquifer discharge entering and leaving the stream along its length. Each baseflow investigation provides physical and chemical information for one point in time. Repeat baseflow investigations can provide long-term information on $\mathrm{C}$-aquifer baseflow trends.

Apart from 2010, the baseflow investigations were conducted in the summer or early fall, when winter snowmelt and summer monsoon surface runoff were negligible. In 2010 the baseflow investigation was conducted during December. Water-quality field parameters $(\mathrm{pH}$, water temperature, specific conductance, and dissolved oxygen concentration) and discharge were measured at each site to characterize physical and geochemical changes from near the headwaters of Chevelon Creek and Clear Creek to their respective confluences with the Little Colorado River. Twelve sites on Clear Creek, 11 sites on Chevelon Creek, and 7 sites on the Little Colorado River were routinely measured for the baseflow investigations (fig. 15). The uppermost sites along Clear Creek and Chevelon Creek are near the observed start of perennial flow, about $9 \mathrm{mi}$ and $12 \mathrm{mi}$ upstream of their respective confluences with the Little Colorado River. Downstream sites were selected based on accessibility to the streams and the presence of springs or manmade structures such as dams or diversions. Sites along the Little Colorado River were chosen to evaluate flow upstream of the confluence with Chevelon Creek (if present), between Chevelon Creek and Clear Creek, and downstream of Clear Creek. Data collected during these baseflow investigations are tabulated by site number and date (tables 4 and 5).

Discharge along the main stem of both Clear Creek and Chevelon Creek increases from headwaters to outflow into the Little Colorado River. Discharge was approximately $2.5 \mathrm{ft}^{3} / \mathrm{s}$ at Clear Creek Site \#14 (about 2 mi below the start of perennial flow and 6 mi upstream of the confluence with the Little Colorado River) and increased to between 3 and $5 \mathrm{ft}^{3} / \mathrm{s}$ at the

Table 3. Clear Creek and Chevelon Creek streamflow gages and periods of record.

\begin{tabular}{lll}
\hline U.S. Geological Survey identification numbers & Station name & Period of record \\
\hline 09399000 & Clear Creek near Winslow, AZ & $6 / 1 / 1906-12 / 31 / 1906$ \\
& $3 / 25 / 1929-2 / 5 / 1934$ \\
& $9 / 24 / 1935-12 / 31 / 1982$ \\
09399100 & Clear Creek blw McHood Lake nr Winslow & $7 / 21 / 2005-9 / 29 / 2006$ \\
09398000 & Chevelon Creek near Winslow, AZ & $1 / 28 / 2005-7 / 18 / 2006$ \\
& & $10 / 1 / 1906-12 / 31 / 1906$ \\
& & $3 / 30 / 1929-2 / 5 / 1934$ \\
& $9 / 1 / 1935-9 / 29 / 1972$ \\
\hline
\end{tabular}




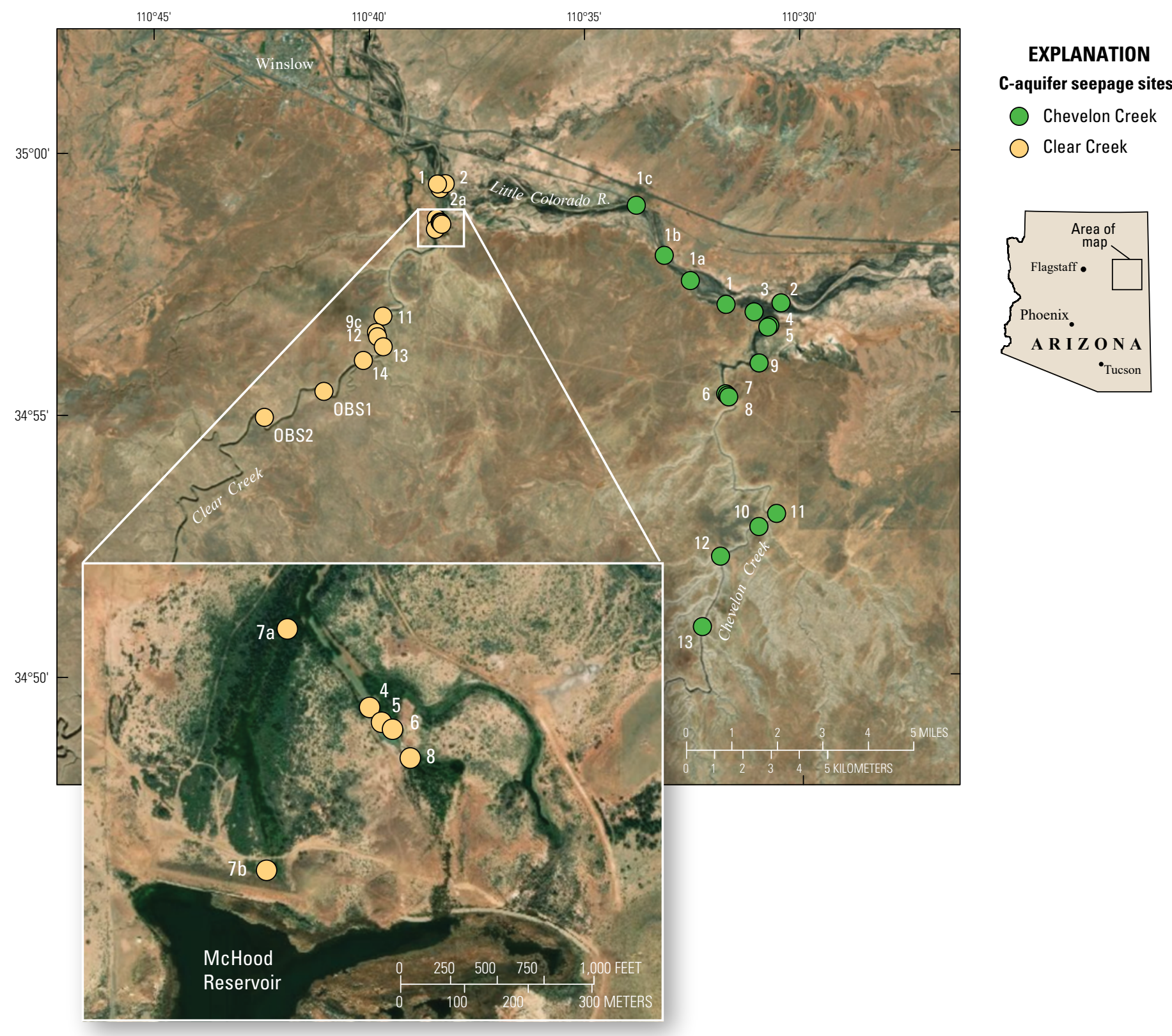

Base imagery from Esri, DigitalGlobe, GeoEye, Earthstar Geographics, CNES/Airbus DS, USDA, USGS,

AeroGRID, IGN and the GIS User. World Geodetic System 84 Projection zone Mercator Auxillary Sphere

Figure 15. Locations of C-aquifer baseflow investigation sites along Clear Creek, Chevelon Creek, and the Little Colorado River, northeastern Arizona. The inset map shows a closer view of the sites just below McHood Reservoir on Clear Creek. 
Table 4. Locations and description of C-aquifer baseflow investigation sites included in this study, northeastern Arizona.

[LCR, Little Colorado River; latitude and longitude are in degrees, minutes, and seconds and referenced to WGS84; ft, feet; dashes, information not available; , about; mi., miles; R., River; Cr., Creek]

\begin{tabular}{|c|c|c|c|c|c|c|}
\hline Station name & $\begin{array}{l}\text { River miles } \\
\text { upstream } \\
\text { of LCR } \\
\text { confluence } \\
\end{array}$ & Station description & $\begin{array}{l}\text { U.S. Geological Survey } \\
\text { identification number }\end{array}$ & Latitude & Longitude & $\begin{array}{c}\text { Land-surface } \\
\text { altitude } \\
\text { (ft above } \\
\text { NAVD29) } \\
\end{array}$ \\
\hline \multicolumn{7}{|c|}{ Little Colorado River Sites } \\
\hline Chevelon Site 2 & -- & $\begin{array}{l}\text { Little Colorado R. } \sim 400 \mathrm{ft} \text { above } \\
\text { Chevelon Cr. confluence }\end{array}$ & 345708110311700 & $34^{\circ} 57^{\prime} 08^{\prime \prime}$ & $-110^{\circ} 31^{\prime} 23^{\prime \prime}$ & 4,903 \\
\hline Chevelon Site 1 & -- & $\begin{array}{l}\text { Little Colorado R. } \sim 600 \mathrm{ft} \text { below } \\
\text { Chevelon Cr. confluence }\end{array}$ & 345706110315300 & $34^{\circ} 57^{\prime} 13^{\prime \prime}$ & $-110^{\circ} 32^{\prime} 08^{\prime \prime}$ & 4,902 \\
\hline Chevelon Site 1a & -- & $\begin{array}{l}\text { Little Colorado R. } \sim 1.2 \text { mi. below } \\
\text { Chevelon Cr. confluence }\end{array}$ & 345732110323400 & $34^{\circ} 57^{\prime} 49^{\prime \prime}$ & $-110^{\circ} 32^{\prime} 53^{\prime \prime}$ & 4,902 \\
\hline Chevelon Site 1b & -- & $\begin{array}{l}\text { Little Colorado R. } \sim 2.7 \text { mi. below } \\
\text { Chevelon Cr. confluence }\end{array}$ & 345805110331400 & $34^{\circ} 57^{\prime} 60^{\prime \prime}$ & $-110^{\circ} 33^{\prime} 09^{\prime \prime}$ & 4,899 \\
\hline Chevelon Site 1c & -- & $\begin{array}{l}\text { Little Colorado R. } \sim 3.5 \text { mi. below } \\
\text { Chevelon Cr. confluence }\end{array}$ & 345900110335300 & $34^{\circ} 58^{\prime} 57^{\prime \prime}$ & $-110^{\circ} 33^{\prime} 41^{\prime \prime}$ & 4,892 \\
\hline Clear Site 2 & -- & $\begin{array}{l}\text { Little Colorado R. above Clear Cr. } \\
\text { Confluence }\end{array}$ & 345913110381700 & $34^{\circ} 59^{\prime} 22^{\prime \prime}$ & $-110^{\circ} 38^{\prime} 23^{\prime \prime}$ & 4,869 \\
\hline Clear Site 1 & -- & $\begin{array}{l}\text { Little Colorado R. below Clear Cr. } \\
\text { confluence }\end{array}$ & 34591 & $34^{\circ} 5$ & -110 & 4,866 \\
\hline \multicolumn{7}{|c|}{ Chevelon Creek Sites } \\
\hline Chevelon Site 3 & 0.5 & Chevelon Cr. $\sim 0.5$ mi. above mouth & 345658110311100 & $34^{\circ} 56^{\prime} 58^{\prime \prime}$ & $-110^{\circ} 31^{\prime} 04^{\prime \prime}$ & 4,909 \\
\hline Chevelon Site 4 & 1.75 & Chevelon $\mathrm{Cr}$. $\sim 450 \mathrm{ft}$ downstream of dam & 345638110305300 & $34^{\circ} 56^{\prime} 44^{\prime \prime}$ & $-110^{\circ} 30^{\prime} 41^{\prime \prime}$ & 4,909 \\
\hline Chevelon Site 5 & 1.75 & Chevelon $\mathrm{Cr}$. $\sim 150 \mathrm{ft}$ downstream of dam & 345636110305400 & $34^{\circ} 56^{\prime} 42^{\prime \prime}$ & $-110^{\circ} 30^{\prime} 42^{\prime \prime}$ & 4,909 \\
\hline Chevelon Site 9 & 2.4 & $\begin{array}{l}\text { Chevelon Cr. downstream from gage } \\
\sim 1.5 \text { miles }\end{array}$ & 345558110305600 & $34^{\circ} 55^{\prime} 55^{\prime \prime}$ & $-110^{\circ} 30^{\prime} 58^{\prime \prime}$ & 4,921 \\
\hline Chevelon Site 6 & 4.25 & Spring \#1 on Chevelon Cr. & 345519110314201 & $34^{\circ} 55^{\prime} 20^{\prime \prime}$ & $-110^{\circ} 31^{\prime} 43^{\prime \prime}$ & 4,943 \\
\hline Chevelon Site 8 & 4.35 & Spring \#2 on Chevelon Cr. & 345511110313201 & $34^{\circ} 55^{\prime} 17^{\prime \prime}$ & $-110^{\circ} 31^{\prime} 39^{\prime \prime}$ & 5,001 \\
\hline Chevelon Site 7 & 4.35 & Chevelon Cr. near Spring \#2 & 345510110313200 & $34^{\circ} 55^{\prime} 18^{\prime \prime}$ & $-110^{\circ} 31^{\prime} 36^{\prime \prime}$ & 4,998 \\
\hline Chevelon Site 11 & 8.5 & Chevelon Cr. at Rock Art access & 345305110303700 & $34^{\circ} 53^{\prime} 08^{\prime \prime}$ & $-110^{\circ} 30^{\prime} 36^{\prime \prime}$ & 5,065 \\
\hline Chevelon Site 10 & 9 & Chevelon Cr. above Bell Cow Canyon & 345251110305700 & $34^{\circ} 52^{\prime} 49^{\prime \prime}$ & $-110^{\circ} 31^{\prime} 07^{\prime \prime}$ & 5,087 \\
\hline Chevelon Site 12 & 10.2 & $\begin{array}{l}\text { Chevelon Cr.halfway between Bell Cow } \\
\text { and Babbitt Tank Canyon }\end{array}$ & 345214110315600 & $34^{\circ} 52^{\prime} 17^{\prime \prime}$ & $-110^{\circ} 31^{\prime} 53^{\prime \prime}$ & 5,088 \\
\hline Chevelon Site 13 & 12.7 & Chevelon Cr. above Babbitt Tank Canyon & 345026110322300 & $34^{\circ} 50^{\prime} 47^{\prime \prime}$ & $-110^{\circ} 32^{\prime} 21^{\prime \prime}$ & 5,091 \\
\hline \multicolumn{7}{|c|}{ Clear Creek Sites } \\
\hline Clear Site 2a & 0 & Clear Cr. $\sim 5 \mathrm{ft}$ above the mouth & 345919110382300 & $34^{\circ} 59^{\prime} 20^{\prime \prime}$ & $-110^{\circ} 38^{\prime} 24^{\prime \prime}$ & 4,860 \\
\hline Clear Site 3 & 0.65 & Clear Cr. below springs, below dam & 345906110383301 & $34^{\circ} 58^{\prime} 46^{\prime \prime}$ & $-110^{\circ} 38^{\prime} 26^{\prime \prime}$ & 4,858 \\
\hline Clear Site 4 & 0.81 & Artesian spring on Clear Cr. below dam & 345813110382701 & $34^{\circ} 58^{\prime} 40^{\prime \prime}$ & $-110^{\circ} 38^{\prime} 22^{\prime \prime}$ & 4,860 \\
\hline Clear Site 6 & 0.82 & Main artesian spring on Clear Cr. below dam & 345859110381801 & $34^{\circ} 58^{\prime} 39^{\prime \prime}$ & $-110^{\circ} 38^{\prime} 21^{\prime \prime}$ & 4,860 \\
\hline Clear Site 5 & 0.83 & $\begin{array}{l}\text { Upstream from main artesian spring on } \\
\text { Clear Cr. }\end{array}$ & 345811110383001 & $34^{\circ} 58^{\prime} 39^{\prime \prime}$ & $-110^{\circ} 38^{\prime} 21^{\prime \prime}$ & 4,860 \\
\hline Clear Site 8 & 0.95 & Clear Creek below the spillway & 345808110383300 & $34^{\circ} 58^{\prime} 38^{\prime \prime}$ & $-110^{\circ} 38^{\prime} 20^{\prime \prime}$ & 4,865 \\
\hline Clear Site 7a & 0.72 & Diversion below aquaduct on Clear $\mathrm{Cr}$. & 345814110382900 & $34^{\circ} 58^{\prime} 44^{\prime \prime}$ & $-110^{\circ} 38^{\prime} 27^{\prime \prime}$ & 4,865 \\
\hline Clear Site $7 \mathrm{~b}$ & 0.95 & Culvert near diversion canal on Clear Cr. & 345812110383101 & $34^{\circ} 58^{\prime} 33^{\prime \prime}$ & $-110^{\circ} 38^{\prime} 28^{\prime \prime}$ & 4,870 \\
\hline Clear Site 11 & 4 & Clear Cr. 2 mi. upstream of Hwy 99 & 345651110394100 & $34^{\circ} 56^{\prime} 53^{\prime \prime}$ & $-110^{\circ} 39^{\prime} 42^{\prime \prime}$ & 4,865 \\
\hline Clear Site 9c & 4.05 & Spring on left side of channel & 345653110394001 & $34^{\circ} 56^{\prime} 43^{\prime \prime}$ & $-110^{\circ} 39^{\prime} 47^{\prime \prime}$ & 4,865 \\
\hline Clear Site 12 & 4.2 & Clear Cr. $\sim 2.3$ mi. upstream of Hwy 99 & 345643110394600 & $34^{\circ} 56^{\prime} 42^{\prime \prime}$ & $-110^{\circ} 39^{\prime} 48^{\prime \prime}$ & 4,867 \\
\hline Clear Site 13 & 4.3 & Clear Cr. $\sim 2.6$ mi. upstream of Hwy 99 & 345637110394900 & $34^{\circ} 56^{\prime} 21^{\prime \prime}$ & $-110^{\circ} 39^{\prime} 42^{\prime \prime}$ & 4,868 \\
\hline Clear Site 14 & 6.4 & Clear Cr. $\sim 3.4$ mi. upstream of Hwy 99 & 345606110400300 & $34^{\circ} 56^{\prime} 05^{\prime \prime}$ & $-110^{\circ} 40^{\prime} 07^{\prime \prime}$ & 4,885 \\
\hline Clear Site OBS1 & 6.77 & $\begin{array}{l}\text { Clear Cr. } \sim 2.0 \text { mi. below start of } \\
\text { perennial flow }\end{array}$ & 345530110411500 & $34^{\circ} 55^{\prime} 27^{\prime \prime}$ & $-110^{\circ} 41^{\prime} 04^{\prime \prime}$ & 4,935 \\
\hline Clear Site OBS2 & 8.74 & Clear Cr. at start of perennial flow & 345502110423000 & $34^{\circ} 54^{\prime} 56^{\prime \prime}$ & $-110^{\circ} 42^{\prime} 28^{\prime \prime}$ & 4,975 \\
\hline
\end{tabular}


Table 5. Measured field parameters at C-aquifer baseflow investigation sites along Clear Creek, Chevelon Creek, and the Little Colorado River, northeastern Arizona.

[LCR, Little Colorado River; $\mathrm{ft}^{3} / \mathrm{s}$, cubic feet per second; ${ }^{\circ} \mathrm{C}$, degrees Celsius; $\mu \mathrm{S} / \mathrm{cm}$, microsiemens per centimeter; $\mathrm{mg} / \mathrm{L}$ milligrams per liter; dashes, information not available; $\sim$, about; mi., miles; R., River; Cr., Creek; E, estimate]

\begin{tabular}{|c|c|c|c|c|c|c|c|c|c|c|}
\hline $\begin{array}{c}\text { Station } \\
\text { name }\end{array}$ & $\begin{array}{c}\text { River miles } \\
\text { upstream of } \\
\text { LCR } \\
\text { confluence }\end{array}$ & $\begin{array}{c}\text { U.S. Geological } \\
\text { Survey } \\
\text { identification } \\
\text { number }\end{array}$ & $\begin{array}{c}\text { Date of } \\
\text { samples }\end{array}$ & Time & $\begin{array}{c}\text { Discharge } \\
\left(\mathrm{ft}^{3} / \mathbf{s}\right)\end{array}$ & $\begin{array}{c}\text { Air } \\
\text { temperature } \\
\left({ }^{\circ} \mathrm{C}\right)\end{array}$ & $\begin{array}{c}\text { Water } \\
\text { temperature } \\
\left({ }^{\circ} \mathrm{C}\right)\end{array}$ & $\begin{array}{c}\text { Specific } \\
\text { conductance } \\
(\mu \mathrm{S} / \mathrm{cm})\end{array}$ & $\mathrm{pH}$ & $\begin{array}{l}\text { Dissolved } \\
\text { oxygen } \\
\text { (mg/L) }\end{array}$ \\
\hline \multicolumn{11}{|c|}{ Little Colorado River Sites } \\
\hline \multirow{8}{*}{$\begin{array}{l}\text { Chevelon } \\
\text { Site } 2\end{array}$} & -- & 345708110311700 & $7 / 6 / 2005$ & $11: 30$ & 0 & 36.2 & -- & -- & -- & -- \\
\hline & & & $6 / 22 / 2006$ & $16: 05$ & 0 & 35.7 & -- & -- & -- & -- \\
\hline & & & $6 / 25 / 2008$ & $11: 30$ & 0 & -- & -- & -- & -- & -- \\
\hline & & & 9/18/2012 & 14:05 & 3.8 & -- & 24.4 & 770 & 8.4 & 6.6 \\
\hline & & & $6 / 18 / 2015$ & $15: 59$ & 1.1 & -- & -- & -- & -- & -- \\
\hline & & & $9 / 20 / 2017$ & 13:00 & 0 & -- & -- & -- & -- & -- \\
\hline & & & $9 / 25 / 2018$ & 10:00 & 0 & -- & -- & -- & -- & -- \\
\hline & & & $6 / 18 / 2019$ & $11: 00$ & 0 & -- & -- & -- & -- & -- \\
\hline \multirow{9}{*}{$\begin{array}{c}\text { Chevelon } \\
\text { Site } 1\end{array}$} & -- & 345706110315300 & $7 / 6 / 2005$ & $11: 50$ & 1.6 & 36.2 & 27 & 4,350 & 8.9 & 7.4 \\
\hline & & & $6 / 22 / 2006$ & $16: 00$ & 1.1 & 35.7 & 31.5 & 4,820 & 8.3 & 7.8 \\
\hline & & & $6 / 25 / 2008$ & 12:02 & 1.5 & 32.6 & 25.5 & 4,900 & 8.4 & 7.1 \\
\hline & & & $12 / 1 / 2010$ & $15: 00$ & 3.1 & 15.7 & 6.9 & -- & -- & -- \\
\hline & & & $9 / 18 / 2012$ & $14: 20$ & 5.4 & -- & 24.6 & 880 & 8.4 & 7.1 \\
\hline & & & $6 / 18 / 2015$ & $15: 18$ & 2.7 & -- & -- & -- & -- & -- \\
\hline & & & 9/19/2017 & $14: 25$ & 1.2 & -- & 21.6 & 3,900 & 7.5 & 7.7 \\
\hline & & & $9 / 25 / 2018$ & $11: 30$ & 1.8 & 30.3 & 25.1 & 4,000 & 8.5 & 9.1 \\
\hline & & & $6 / 18 / 2019$ & $11: 00$ & 1.4 & -- & 24.7 & 4,570 & 7.8 & 6.2 \\
\hline \multicolumn{11}{|c|}{ Chevelon Site } \\
\hline \multirow{8}{*}{$\begin{array}{r}\text { Chevelon } \\
\text { Site 1a }\end{array}$} & -- & 345732110323400 & $7 / 7 / 2005$ & $11: 45$ & 1.8 & 34.5 & 30.9 & 4,500 & 8.5 & 6.5 \\
\hline & & & $6 / 23 / 2006$ & $8: 35$ & 1.0 & 31.8 & 20.3 & 5,020 & 8.4 & 8.4 \\
\hline & & & $12 / 3 / 2010$ & $11: 20$ & 3.4 & -- & 3.9 & 3,760 & 7.8 & 11.0 \\
\hline & & & $9 / 18 / 2012$ & $16: 11$ & 5.3 & -- & 25.1 & 940 & 8.4 & 5.8 \\
\hline & & & $6 / 18 / 2015$ & $10: 33$ & 1.7 & -- & 29.8 & 1,260 & 8.0 & 6.7 \\
\hline & & & $9 / 19 / 2017$ & $14: 58$ & 1.1 & -- & 24.2 & 4,130 & 8.5 & 7.4 \\
\hline & & & $9 / 25 / 2018$ & $16: 05$ & 1.7 & 37.4 & 25.6 & 4,160 & 8.6 & 7.6 \\
\hline & & & $6 / 18 / 2019$ & $13: 35$ & 1.6 & -- & 30.1 & 5,060 & 8.2 & 0.4 \\
\hline \multirow{9}{*}{$\begin{array}{c}\text { Chevelon } \\
\text { Site } 1 \mathrm{~b}\end{array}$} & -- & 345805110331400 & $7 / 7 / 2005$ & $13: 30$ & $2.2 \mathrm{E}$ & 34.5 & -- & -- & -- & -- \\
\hline & & & $6 / 23 / 2006$ & $9: 45$ & 1.1 & 31.8 & 23 & 5,220 & 8.5 & 8.4 \\
\hline & & & $6 / 25 / 2008$ & $14: 55$ & 1.8 & 34.3 & 29.4 & 5,130 & 8.5 & 6.4 \\
\hline & & & $12 / 3 / 2010$ & $12: 30$ & 3.8 & -- & 7.1 & 4020 & 8.1 & 10.8 \\
\hline & & & $9 / 18 / 2012$ & $16: 25$ & -- & -- & 24.5 & 910 & 6.8 & 8.4 \\
\hline & & & $6 / 18 / 2015$ & $11: 32$ & 1.7 & -- & 31.6 & 1,660 & 8.1 & 6.6 \\
\hline & & & $9 / 19 / 2017$ & $17: 21$ & 0.78 & -- & 19.8 & 4,310 & 8.6 & 7.6 \\
\hline & & & $9 / 25 / 2018$ & 14:00 & 1.9 & -- & 27.5 & 4,300 & 8.5 & 7.1 \\
\hline & & & $6 / 18 / 2019$ & $14: 52$ & 1.8 & -- & 29.5 & 5,530 & 8.3 & 7.0 \\
\hline
\end{tabular}


Table 5. Continued

\begin{tabular}{|c|c|c|c|c|c|c|c|c|c|c|}
\hline $\begin{array}{c}\text { Station } \\
\text { name }\end{array}$ & $\begin{array}{c}\text { River miles } \\
\text { upstream of } \\
\text { LCR } \\
\text { confluence }\end{array}$ & $\begin{array}{c}\text { U.S. Geological } \\
\text { Survey } \\
\text { identification } \\
\text { number }\end{array}$ & $\begin{array}{l}\text { Date of } \\
\text { samples }\end{array}$ & Time & $\begin{array}{c}\text { Discharge } \\
\left(\mathrm{ft}^{3} / \mathrm{s}\right)\end{array}$ & $\begin{array}{c}\text { Air } \\
\text { temperature } \\
\left({ }^{\circ} \mathrm{C}\right)\end{array}$ & $\begin{array}{c}\text { Water } \\
\text { temperature } \\
\left({ }^{\circ} \mathrm{C}\right)\end{array}$ & $\begin{array}{c}\text { Specific } \\
\text { conductance } \\
(\mu \mathrm{S} / \mathrm{cm})\end{array}$ & $\mathbf{p H}$ & $\begin{array}{l}\text { Dissolved } \\
\text { oxygen } \\
\text { (mg/L) }\end{array}$ \\
\hline \multicolumn{11}{|c|}{ Chevelon Site-Continued } \\
\hline \multirow{5}{*}{$\begin{array}{l}\text { Chevelon } \\
\text { Site 1c }\end{array}$} & -- & 345900110335300 & $6 / 23 / 2006$ & $13: 45$ & 0.71 & 39.4 & 33.1 & 5,380 & 8.6 & 8.5 \\
\hline & & & $9 / 19 / 2012$ & 13:00 & 4.4 & -- & 24.5 & 1,070 & 7.9 & 7.3 \\
\hline & & & $6 / 18 / 2015$ & $13: 27$ & 1.4 & -- & -- & -- & -- & -- \\
\hline & & & $9 / 20 / 2017$ & $9: 12$ & 1.2 & -- & 14.9 & 4,120 & 8.4 & 9.2 \\
\hline & & & $9 / 25 / 2018$ & $17: 00$ & 1.4 & -- & 23.9 & 4,350 & 8.5 & 6.7 \\
\hline \multirow{6}{*}{ Clear Site 2} & & & $6 / 26 / 2008$ & $12: 00$ & 0 & -- & -- & -- & -- & -- \\
\hline & & & $12 / 2 / 2010$ & $17: 20$ & 4.8 & 15.6 & 7.4 & 3,980 & 7.4 & 10.5 \\
\hline & & & 9/19/2012 & 9:00 & 4.1 & 19.7 & 14.2 & 910 & 8.1 & 6.1 \\
\hline & & & $9 / 20 / 2017$ & $11: 00$ & 0 & -- & -- & -- & -- & -- \\
\hline & & & $9 / 26 / 2018$ & $10: 00$ & 0.98 & 25.6 & 19.1 & 4,180 & 8.6 & 6.02 \\
\hline & & & $6 / 19 / 2019$ & $13: 45$ & $5 \times 10^{-6}$ & -- & 30.4 & 7,130 & 8.0 & 4.6 \\
\hline \multirow[t]{3}{*}{ Clear Site 1} & -- & 345913110381800 & $6 / 30 / 2005$ & 13:05 & 5.4 & 33.1 & 17.8 & 5,460 & 7.7 & 6.1 \\
\hline & & & $6 / 28 / 2006$ & 10:00 & 4.8 & -- & 19.7 & 6,110 & 7.9 & 7.8 \\
\hline & & & $6 / 26 / 2008$ & $12: 07$ & 5.5 & -- & -- & -- & -- & -- \\
\hline \multicolumn{11}{|c|}{ Chevelon Creek Sites } \\
\hline \multirow{8}{*}{$\begin{array}{c}\text { Chevelon } \\
\text { Site } 3\end{array}$} & 0.5 & 345658110311100 & $7 / 6 / 2005$ & $13: 45$ & 2.6 & 35.5 & 29.5 & 3,880 & 8.9 & -- \\
\hline & & & $6 / 22 / 2006$ & $14: 30$ & 1.2 & 31.8 & 26.3 & 4,680 & 8.1 & 8.9 \\
\hline & & & $6 / 25 / 2008$ & $13: 25$ & 1.9 & 36.4 & 26.1 & 4,480 & 8.3 & 6.5 \\
\hline & & & $12 / 1 / 2010$ & $13: 44$ & 3.0 & 6.9 & 4.9 & -- & -- & -- \\
\hline & & & $9 / 18 / 2012$ & $16: 10$ & 1.6 & -- & -- & -- & -- & -- \\
\hline & & & 9/19/2017 & 13:04 & 1.5 & -- & 18.3 & 3,840 & 7.2 & 8.1 \\
\hline & & & $9 / 25 / 2018$ & $14: 00$ & 1.5 & 28 & 25.5 & 4,040 & 8.7 & 14.1 \\
\hline & & & $6 / 18 / 2019$ & $11: 20$ & 1.7 & 43 & 22.3 & 4,830 & 7.6 & 5.7 \\
\hline \multirow{7}{*}{$\begin{array}{c}\text { Chevelon } \\
\text { Site } 4\end{array}$} & 1.75 & 345638110305300 & $7 / 6 / 2005$ & $16: 00$ & 2.8 & 36.2 & 26.4 & 3,610 & 8.6 & 7.4 \\
\hline & & & $6 / 22 / 2006$ & $12: 30$ & 1.6 & 32.6 & 23.6 & 4,010 & 8.9 & 7.4 \\
\hline & & & $6 / 25 / 2008$ & $9: 37$ & 1.9 & -- & 23.8 & 3,960 & 8.4 & 5.9 \\
\hline & & & $12 / 1 / 2010$ & $12: 00$ & -- & 8.6 & 4.4 & 3,520 & 8.6 & 10.1 \\
\hline & & & $9 / 18 / 2012$ & $14: 30$ & -- & -- & 24.4 & 1,260 & 8.5 & 9.4 \\
\hline & & & $9 / 25 / 2018$ & $12: 30$ & -- & -- & 21 & 3,820 & 8.2 & 6.8 \\
\hline & & & $6 / 18 / 2019$ & $14: 00$ & -- & 37.1 & 23.6 & 3,920 & 8.4 & 7.5 \\
\hline
\end{tabular}


Table 5. Continued

\begin{tabular}{|c|c|c|c|c|c|c|c|c|c|c|}
\hline $\begin{array}{l}\text { Station } \\
\text { name }\end{array}$ & $\begin{array}{c}\text { River miles } \\
\text { upstream of } \\
\text { LCR } \\
\text { confluence }\end{array}$ & $\begin{array}{l}\text { U.S. Geological } \\
\text { Survey } \\
\text { identification } \\
\text { number }\end{array}$ & $\begin{array}{l}\text { Date of } \\
\text { samples }\end{array}$ & Time & $\begin{array}{c}\text { Discharge } \\
\left(\mathrm{ft}^{3} / \mathbf{s}\right)\end{array}$ & $\begin{array}{c}\text { Air } \\
\text { temperature } \\
\left({ }^{\circ} \mathrm{C}\right)\end{array}$ & $\begin{array}{c}\text { Water } \\
\text { temperature } \\
\left({ }^{\circ} \mathrm{C}\right)\end{array}$ & $\begin{array}{c}\text { Specific } \\
\text { conductance } \\
\text { ( } \mathrm{SS} / \mathrm{cm})\end{array}$ & $\mathbf{p H}$ & $\begin{array}{c}\text { Dissolved } \\
\text { oxygen } \\
\text { (mg/L) }\end{array}$ \\
\hline \multicolumn{11}{|c|}{ Chevelon Creek Sites-Coontinued } \\
\hline \multirow{8}{*}{$\begin{array}{l}\text { Chevelon } \\
\text { Site } 5\end{array}$} & 1.75 & 345636110305400 & $7 / 6 / 2005$ & $16: 15$ & 2.2 & 36.1 & 26.2 & 3,610 & 8.7 & 7.3 \\
\hline & & & $6 / 22 / 2006$ & $9: 45$ & 2.2 & 30.9 & 23.4 & 4,000 & 8.5 & 7.5 \\
\hline & & & $12 / 1 / 2010$ & $11: 02$ & 2.9 & 7.4 & 4.9 & 3,510 & 7.8 & 10.2 \\
\hline & & & $9 / 18 / 2012$ & $10: 54$ & 2.3 & -- & 19.0 & 2,410 & 8.7 & -- \\
\hline & & & $6 / 18 / 2015$ & $13: 00$ & 2.1 & -- & -- & -- & -- & -- \\
\hline & & & 9/19/2017 & $11: 14$ & 2.8 & -- & 19.8 & 3,780 & 8.3 & 8.3 \\
\hline & & & $9 / 25 / 2018$ & $9: 30$ & 2.4 & -- & 21 & 3,840 & 8.3 & 7.9 \\
\hline & & & $6 / 18 / 2019$ & $13: 20$ & 1.0 & 32.3 & 24.7 & 3,910 & 8.4 & 7.9 \\
\hline \multirow{2}{*}{$\begin{array}{l}\text { Chevelon } \\
\text { Site } 9\end{array}$} & 2.4 & 345558110305600 & $7 / 6 / 2005$ & $16: 20$ & -- & 36.5 & 25.6 & 3,150 & 7.7 & 7.4 \\
\hline & & & $6 / 23 / 2006$ & $10: 00$ & -- & 28 & 24.5 & 3,810 & 8.2 & 7.7 \\
\hline \multirow{7}{*}{$\begin{array}{l}\text { Chevelon } \\
\text { Site } 6\end{array}$} & 4.25 & 345519110314201 & $7 / 6 / 2005$ & $13: 20$ & 0.11 & 37 & 17.0 & 4,800 & 6.9 & 3.0 \\
\hline & & & $6 / 23 / 2006$ & $10: 55$ & -- & 27 & 17 & 4,660 & 7.1 & 1.6 \\
\hline & & & $12 / 1 / 2010$ & $13: 45$ & 0.13 & 8 & 17.1 & 4680 & 7.9 & 4.0 \\
\hline & & & 9/18/2012 & $12: 00$ & 0.06 & -- & 17.1 & 4730 & 7.7 & 3.9 \\
\hline & & & 9/19/2017 & $12: 40$ & 0.06 & -- & 17.1 & 4,720 & 7.4 & 3.3 \\
\hline & & & $9 / 25 / 2018$ & $12: 30$ & 0.06 & -- & 17.1 & 4,520 & 7.6 & 3.2 \\
\hline & & & $6 / 18 / 2019$ & $13: 05$ & 0.06 & -- & 17.5 & 4,730 & 7.3 & 2.5 \\
\hline \multirow{2}{*}{$\begin{array}{l}\text { Chevelon } \\
\text { Site } 8\end{array}$} & 4.35 & 345511110313201 & $7 / 6 / 2005$ & $12: 31$ & 0 & 36.5 & 22.0 & 4,700 & 7.7 & 7.0 \\
\hline & & & $6 / 18 / 2019$ & $15: 05$ & $1.8 \times 10^{-4}$ & -- & 21.8 & 4,770 & 7.7 & 4.6 \\
\hline \multirow{3}{*}{$\begin{array}{l}\text { Chevelon } \\
\text { Site } 7\end{array}$} & 4.35 & 345510110313200 & $7 / 6 / 2005$ & $12: 45$ & -- & 36.5 & 22.6 & 3,240 & 7.6 & 3.8 \\
\hline & & & $6 / 23 / 2006$ & $11: 45$ & -- & 27 & 22.4 & 3,470 & 7.8 & 5.2 \\
\hline & & & $6 / 18 / 2019$ & $14: 30$ & -- & -- & 21.5 & 3,520 & 7.8 & 5.6 \\
\hline \multirow{8}{*}{$\begin{array}{c}\text { Chevelon } \\
\text { Site } 11\end{array}$} & 8.5 & 345305110303700 & $7 / 7 / 2005$ & $12: 45$ & 0.36 & 29.5 & 25.6 & 810 & 7.9 & 8.2 \\
\hline & & & $6 / 22 / 2006$ & $10: 00$ & 0.29 & -- & 28.5 & 940 & 7.9 & 6.1 \\
\hline & & & $12 / 1 / 2010$ & -- & 0.53 & -- & 2.8 & 920 & 8.3 & 11.3 \\
\hline & & & $9 / 18 / 2012$ & $10: 00$ & 0.5 & 20.4 & 15.7 & 840 & 7.8 & 6.7 \\
\hline & & & $6 / 18 / 2015$ & $11: 30$ & 0.55 & 30.5 & 26.2 & 590 & 7.8 & 5.3 \\
\hline & & & 9/19/2017 & $10: 29$ & 0.41 & -- & 15.0 & 860 & 7.8 & 7.5 \\
\hline & & & $9 / 25 / 2018$ & $10: 00$ & 0.83 & -- & 18.5 & 920 & 7.8 & 4.4 \\
\hline & & & $6 / 18 / 2019$ & $10: 15$ & 0.42 & -- & 20.4 & 890 & 7.8 & 6.2 \\
\hline \multirow{6}{*}{$\begin{array}{r}\text { Chevelon } \\
\text { Site } 10\end{array}$} & 9 & 345251110305700 & $7 / 7 / 2005$ & $11: 58$ & 0.53 & 26.0 & 24.7 & 820 & 7.7 & 6.4 \\
\hline & & & $6 / 22 / 2006$ & $10: 30$ & 0.44 & 29.5 & 23.7 & 1,080 & 7.6 & 5.9 \\
\hline & & & $12 / 1 / 2010$ & $13: 45$ & 0.43 & -- & 2.8 & 920 & 8.2 & 9.7 \\
\hline & & & $9 / 18 / 2012$ & $10: 30$ & 0.68 & 23.0 & 16.6 & 850 & 7.8 & 6.7 \\
\hline & & & $6 / 18 / 2015$ & $13: 35$ & 0.53 & 33 & 28.9 & 590 & 7.9 & 6.2 \\
\hline & & & 9/19/2017 & $11: 43$ & 0.33 & -- & 16.8 & 930 & 7.8 & 7.3 \\
\hline \multirow{4}{*}{$\begin{array}{c}\text { Chevelon } \\
\text { Site } 12\end{array}$} & 10.2 & 345214110315600 & $6 / 22 / 2006$ & $15: 00$ & 0.32 & 35 & 27.3 & 1,220 & 8.2 & 7.3 \\
\hline & & & $12 / 2 / 2010$ & $12: 30$ & 0.4 & 8.1 & 4.2 & 980 & 8.1 & 10.9 \\
\hline & & & 9/17/2012 & $13: 31$ & 0.38 & -- & -- & -- & -- & -- \\
\hline & & & 9/19/2017 & $11: 02$ & 0.38 & -- & 18.5 & 1,050 & 7.8 & 6.2 \\
\hline $\begin{array}{r}\text { Chevelon } \\
\text { Site } 13\end{array}$ & 12.7 & 345026110322300 & $6 / 23 / 2006$ & $10: 40$ & 0.45 & 28.4 & 21.8 & 1,170 & 7.8 & 7.1 \\
\hline
\end{tabular}


Table 5. Continued

\begin{tabular}{|c|c|c|c|c|c|c|c|c|c|c|}
\hline $\begin{array}{l}\text { Station } \\
\text { name }\end{array}$ & $\begin{array}{l}\text { River miles } \\
\text { upstream of } \\
\text { LCR } \\
\text { confluence }\end{array}$ & $\begin{array}{c}\text { U.S. Geological } \\
\text { Survey } \\
\text { identification } \\
\text { number }\end{array}$ & $\begin{array}{l}\text { Date of } \\
\text { samples }\end{array}$ & Time & $\begin{array}{c}\text { Discharge } \\
\left(\mathrm{ft}^{3} / \mathbf{s}\right)\end{array}$ & $\begin{array}{c}\text { Air } \\
\text { temperature } \\
\left({ }^{\circ} \mathrm{C}\right)\end{array}$ & $\begin{array}{c}\text { Water } \\
\text { temperature } \\
\left({ }^{\circ} \mathrm{C}\right)\end{array}$ & $\begin{array}{c}\text { Specific } \\
\text { conductance } \\
(\mu \mathrm{S} / \mathrm{cm})\end{array}$ & $\mathrm{pH}$ & $\begin{array}{l}\text { Dissolved } \\
\text { oxygen } \\
\text { (mg/L) }\end{array}$ \\
\hline \multicolumn{11}{|c|}{ Clear Creek Sites } \\
\hline \multirow[t]{6}{*}{ Clear Site 2a } & 0 & 345919110382300 & $6 / 28 / 2006$ & 9:00 & 3.3 & 25.1 & 17.6 & 6,070 & 7.9 & 7.1 \\
\hline & & & $12 / 2 / 2010$ & 14:00 & 6.1 & -- & 15.5 & 4,260 & 7.4 & 8.9 \\
\hline & & & $9 / 19 / 2012$ & $8: 45$ & 4.9 & 19.7 & 16.9 & 4,770 & 7.8 & 14.6 \\
\hline & & & $9 / 20 / 2017$ & $11: 44$ & 3.1 & -- & 20.7 & 5,970 & 7.5 & 10.2 \\
\hline & & & $9 / 26 / 2018$ & 9:15 & 3.0 & 21.1 & 17.5 & 4,870 & 8.1 & 7.8 \\
\hline & & & $6 / 19 / 2019$ & $11: 00$ & 3.8 & -- & 19.9 & 6,010 & 7.8 & 6.7 \\
\hline \multirow[t]{2}{*}{ Clear Site 3} & 0.65 & 345906110383301 & $6 / 30 / 2005$ & $14: 35$ & 5.4 & 43.8 & 18.3 & 6,300 & 7.3 & 4.4 \\
\hline & & & $6 / 28 / 2006$ & 13:00 & 4.3 & -- & 18.8 & 6,180 & 7.6 & 4.4 \\
\hline \multirow[t]{6}{*}{ Clear Site 4} & 0.81 & 345813110382701 & $6 / 30 / 2005$ & $16: 00$ & $2 \times 10^{-3}$ & 43.8 & 17.1 & 6,490 & 7.3 & 2.0 \\
\hline & & & $6 / 28 / 2006$ & $14: 00$ & 0.05 & -- & 16.9 & 6,220 & 7.4 & 1.4 \\
\hline & & & $12 / 2 / 2010$ & -- & -- & 12.8 & 17.2 & 5,780 & 7.4 & 1.9 \\
\hline & & & $9 / 19 / 2012$ & $9: 30$ & 0.8 & -- & 17.0 & 6,050 & 7.5 & 1.5 \\
\hline & & & $9 / 20 / 2017$ & $10: 00$ & -- & -- & 17.3 & 6,110 & 7.2 & 1.3 \\
\hline & & & $9 / 26 / 2018$ & $10: 00$ & -- & -- & 17.4 & 6,160 & 7.5 & 1.9 \\
\hline \multirow[t]{4}{*}{ Clear Site 6} & 0.82 & 345859110381801 & $6 / 30 / 2005$ & $16: 45$ & -- & 42 & 16.7 & 6,250 & 7.2 & 2.8 \\
\hline & & & $6 / 28 / 2006$ & $14: 20$ & -- & -- & 16.8 & 6,390 & 7.4 & 1.8 \\
\hline & & & 9/19/2012 & -- & -- & -- & 17.2 & 6,070 & 7.6 & 1.7 \\
\hline & & & $6 / 19 / 2019$ & $10: 15$ & -- & 33.8 & 17.4 & 6,040 & 7.1 & 1.5 \\
\hline \multirow[t]{3}{*}{ Clear Site 5} & 0.83 & 345811110383001 & $6 / 30 / 2005$ & $16: 25$ & 0.10 & 43.8 & 16.8 & 5,980 & 7.2 & 1.5 \\
\hline & & & $6 / 28 / 2006$ & $13: 50$ & 0.08 & -- & 17 & 6,240 & 7.4 & 1.5 \\
\hline & & & $12 / 2 / 2010$ & $11: 40$ & 0.17 & 11.6 & 17.6 & 5,950 & 7.3 & 1.4 \\
\hline \multirow[t]{4}{*}{ Clear Site 8} & 0.95 & 345808110383300 & $6 / 30 / 2005$ & -- & 0 & -- & 27 & 27,000 & 7.5 & 5.3 \\
\hline & & & $12 / 2 / 2010$ & $10: 00$ & 2.6 & 5.2 & 4.9 & 1,840 & 7.8 & 11.1 \\
\hline & & & $9 / 26 / 2018$ & $9: 45$ & 0.03 & -- & 19.3 & 6,440 & 8.0 & 7.8 \\
\hline & & & $6 / 19 / 2019$ & $11: 00$ & 0.23 & 43.2 & 22.2 & 4,650 & 7.8 & 6.9 \\
\hline \multirow[t]{5}{*}{ Clear Site 7a } & 0.72 & 345814110382900 & $6 / 30 / 2005$ & $19: 00$ & 0.31 & 36.1 & 18.9 & 1,190 & 7.3 & 3.6 \\
\hline & & & $6 / 28 / 2006$ & $15: 40$ & 0.03 & 31.6 & 25.6 & 2,600 & 8.8 & 7.1 \\
\hline & & & 9/20/2017 & $12: 10$ & -- & -- & 17.7 & 2,310 & 8.1 & 7.7 \\
\hline & & & 9/26/2018 & 9:00 & 0.01 & -- & 14.1 & 2,600 & 8.0 & 7.9 \\
\hline & & & 6/19/2019 & $14: 00$ & 0.02 & 32.8 & 29.2 & 2,530 & 8.3 & 6.2 \\
\hline \multirow{6}{*}{$\begin{array}{c}\text { Clear Site } \\
7 \mathrm{~b}\end{array}$} & 0.95 & 345812110383101 & $6 / 30 / 2005$ & $18: 30$ & $2 \times 10^{-3}$ & 36.1 & 21.3 & 3,650 & 9.2 & 5.3 \\
\hline & & & $6 / 28 / 2006$ & $15: 40$ & 0 & 31.6 & -- & -- & -- & -- \\
\hline & & & $12 / 2 / 2010$ & $12: 30$ & 0.03 & -- & 12.9 & 9,840 & 7.0 & -- \\
\hline & & & 9/20/2017 & 9:30 & $4.6 \times 10^{-3}$ & -- & 13 & 2,110 & 7.2 & 0.4 \\
\hline & & & $9 / 25 / 2018$ & $16: 25$ & $3 \times 10^{-3}$ & -- & 19.9 & 2,470 & -- & 0.4 \\
\hline & & & $6 / 18 / 2019$ & $17: 10$ & 0.06 & 29.9 & 17.5 & 2,790 & 7.3 & 2.2 \\
\hline \multirow[t]{3}{*}{ Clear Site 11} & 4 & 345651110394100 & $6 / 30 / 2005$ & $13: 30$ & 3.2 & 37.5 & 19.3 & 2,000 & 7.5 & 9.0 \\
\hline & & & $6 / 28 / 2006$ & $17: 10$ & 2.9 & 28.5 & 22.6 & 2,000 & 8.1 & 8.5 \\
\hline & & & $9 / 19 / 2012$ & -- & -- & -- & 17.2 & 2,020 & 8.0 & 7.2 \\
\hline
\end{tabular}


Table 5. Continued

\begin{tabular}{|c|c|c|c|c|c|c|c|c|c|c|}
\hline $\begin{array}{l}\text { Station } \\
\text { name }\end{array}$ & $\begin{array}{l}\text { River miles } \\
\text { upstream of } \\
\text { LCR } \\
\text { confluence }\end{array}$ & $\begin{array}{c}\text { U.S. Geological } \\
\text { Survey } \\
\text { identification } \\
\text { number }\end{array}$ & $\begin{array}{c}\text { Date of } \\
\text { samples }\end{array}$ & Time & $\begin{array}{c}\text { Discharge } \\
\left(\mathrm{ft}^{3} / \mathbf{s}\right)\end{array}$ & $\begin{array}{c}\text { Air } \\
\text { temperature } \\
\left({ }^{\circ} \mathrm{C}\right)\end{array}$ & $\begin{array}{c}\text { Water } \\
\text { temperature } \\
\left({ }^{\circ} \mathrm{C}\right)\end{array}$ & $\begin{array}{c}\text { Specific } \\
\text { conductance } \\
\text { ( } \mathrm{HS} / \mathrm{cm})\end{array}$ & $\mathrm{pH}$ & $\begin{array}{c}\text { Dissolved } \\
\text { oxygen } \\
\text { (mg/L) }\end{array}$ \\
\hline \multicolumn{11}{|c|}{ Clear Creek Sites-Continued } \\
\hline \multirow[t]{5}{*}{ Clear Site 9c } & 4.05 & 345653110394001 & $6 / 28 / 2006$ & $17: 55$ & 0.01 & 34 & 16.8 & 2,300 & 7.6 & 7.3 \\
\hline & & & $12 / 2 / 2010$ & $14: 15$ & 0.02 & -- & 16.5 & 2370 & 7.8 & -- \\
\hline & & & $9 / 20 / 2017$ & 13:00 & 0.02 & -- & 16.9 & 2,320 & 7.7 & 7.3 \\
\hline & & & $9 / 26 / 2018$ & $10: 50$ & 0.01 & -- & 16.8 & 2,140 & -- & 7.3 \\
\hline & & & $6 / 19 / 2019$ & 11:05 & 0.02 & -- & 16.7 & 2,320 & 7.5 & 7.3 \\
\hline \multirow{4}{*}{$\begin{array}{c}\text { Clear Site } \\
12\end{array}$} & 4.2 & 345643110394600 & $6 / 30 / 2005$ & $17: 05$ & 2.5 & -- & 20.5 & 1,960 & 7.9 & 9.5 \\
\hline & & & $6 / 28 / 2006$ & $16: 00$ & 2.2 & 33.5 & 23.2 & 1,990 & 8.2 & 8.7 \\
\hline & & & $9 / 19 / 2012$ & -- & -- & -- & 16.2 & 1,960 & 7.9 & 7.1 \\
\hline & & & $9 / 20 / 2017$ & $12: 28$ & 2.4 & -- & 16.8 & 1,960 & 8.1 & 8.5 \\
\hline \multirow{6}{*}{$\begin{array}{c}\text { Clear Site } \\
13\end{array}$} & 4.3 & 345637110394900 & $6 / 30 / 2005$ & $16: 40$ & $2.5 \mathrm{E}$ & -- & 20.3 & 1,210 & 8.0 & 9.3 \\
\hline & & & $12 / 2 / 2010$ & $11: 30$ & 2.3 & 4.5 & 4.0 & 2030 & 8.4 & 11.2 \\
\hline & & & $9 / 19 / 2012$ & $12: 25$ & 2.8 & -- & 16.4 & 1,950 & 8.0 & 7.3 \\
\hline & & & $9 / 20 / 2017$ & $11: 25$ & 2.8 & -- & 17.5 & 1,950 & 8.1 & 8.9 \\
\hline & & & $9 / 26 / 2018$ & $12: 10$ & 1.2 & -- & 19.1 & 1,880 & 8.5 & -- \\
\hline & & & $6 / 19 / 2019$ & $12: 20$ & 2.9 & -- & 21.5 & 1,860 & 8.4 & 10.7 \\
\hline \multirow{2}{*}{$\begin{array}{c}\text { Clear Site } \\
14\end{array}$} & 6.4 & 345606110400300 & $6 / 28 / 2006$ & $13: 55$ & 2.3 & 35.5 & 23.3 & 1,980 & 8.1 & 8.6 \\
\hline & & & $9 / 19 / 2012$ & $11: 35$ & 2.5 & -- & 16.0 & 1,920 & 7.8 & 7.8 \\
\hline $\begin{array}{c}\text { Clear Site } \\
\text { OBS1 }\end{array}$ & 6.77 & 345530110411500 & $7 / 1 / 2005$ & -- & $0.5 \mathrm{E}$ & -- & 20.3 & 1,210 & 8.0 & 9.3 \\
\hline $\begin{array}{c}\text { Clear Site } \\
\text { OBS2 }\end{array}$ & 8.74 & 345502110423000 & $6 / 28 / 2006$ & -- & 0 & -- & -- & -- & -- & -- \\
\hline
\end{tabular}

confluence with the Little Colorado River (fig. 16A). Chevelon Creek Site \#12 (about 1.4 mi below the start of perennial flow) had discharges around $0.3 \mathrm{ft}^{3} / \mathrm{s}$, while discharge values at Chevelon Creek near the confluence with the Little Colorado River ranged from $1.15 \mathrm{ft}^{3} / \mathrm{s}$ to $3.0 \mathrm{ft}^{3} / \mathrm{s}$ (fig. 16B). The Little Colorado River is ephemeral above the confluence with Chevelon Creek. Baseflow investigations during years when there is flow above the Chevelon Creek confluence may be indicative of surface water runoff from farther upstream. Flow in the Little Colorado River remains relatively steady for the 3.5 miles downstream of the Chevelon Creek confluence (fig. 16C). The Little Colorado River stream channel is wide and shallow (approximately $30 \mathrm{ft}$ across and less than one foot deep); the channel bottom is soft sand and mud that in some places presents as quicksand. These conditions contribute an additional source of error in the streamflow discharge measurements for the Little Colorado River.

Along with changes in discharge, water chemistry can provide valuable insights into the geochemical evolution and sources of groundwater to streams. Water-quality field parameters ( $\mathrm{pH}$, water temperature, specific conductance, and dissolved oxygen concentration) were measured at field sites, and water samples were collected and analyzed for water chemistry (major ions, nutrients, iron, boron, and arsenic) 

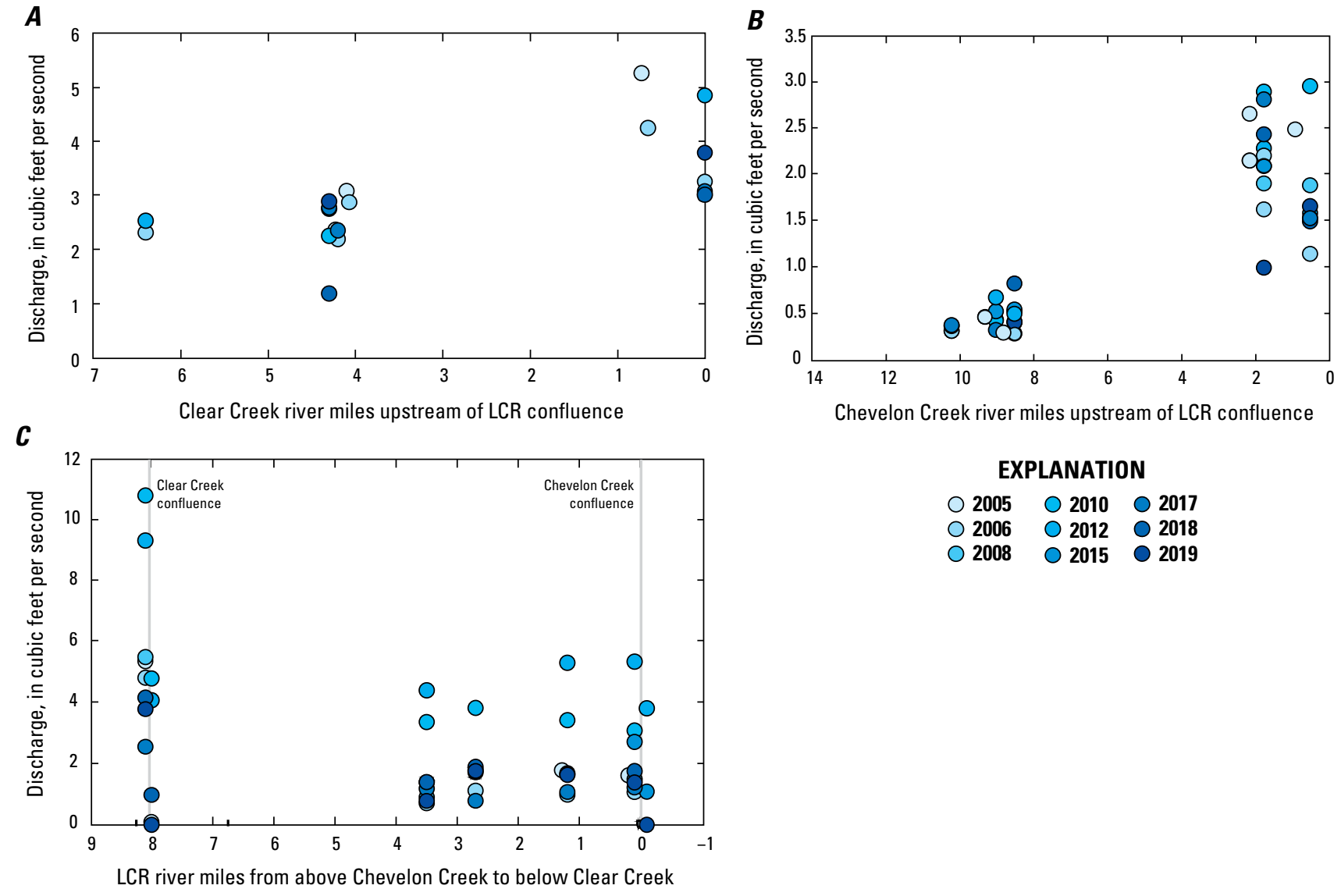

Figure 16. Graphs of discharge versus river miles on Clear Creek upstream of the Little Colorado River confluence $(A)$, on Chevelon Creek upstream of the Little Colorado River confluence $(B)$, and on the Little Colorado River from above the Chevelon Creek confluence to below the Clear Creek confluence (C). LCR, Little Colorado River.

for selected sites in 2005 and 2006 (summarized in Brown and Macy, 2012). The median specific conductance value for each baseflow investigation site is plotted on fig. 17. In both the perennial Clear Creek and Chevelon Creek reaches, the specific conductance increases from the headwaters to the confluence with the Little Colorado River. The specific conductance values of the Little Colorado River remain relatively constant between the two tributaries.

Figures $18 \mathrm{~A}$ and $18 B$ illustrate the median specific conductance values along Clear Creek, ranging from $1,912 \mu \mathrm{S} / \mathrm{cm}$ at Clear Creek Site \#13 to 6,159 $\mu \mathrm{S} / \mathrm{cm}$ at Clear Creek Site \#6. Clear Creek Site \#9c, a small spring discharging from the side of the Coconino Sandstone canyon wall, and the main channel sites around it (Clear Creek Sites \#11, \#12, and \#13) have the lowest specific conductance values.

Roughly three miles downstream and below the dam forming McHood Reservoir, the spring complex of Clear Creek Sites $\# 4$, \#5, and \#6 has more than three times the specific conductance values of Clear Creek Site \#9c. Specific conductance at the spring complex has consistently been higher than upstream sites. Clear Creek Site \#11, a channel site just downstream of the spring at Clear Creek Site \#9c, and Clear Creek Site \#6, the main artesian spring outlet, were sampled for water chemistry in 2005 and 2006. The water chemistry suggests two distinct water 


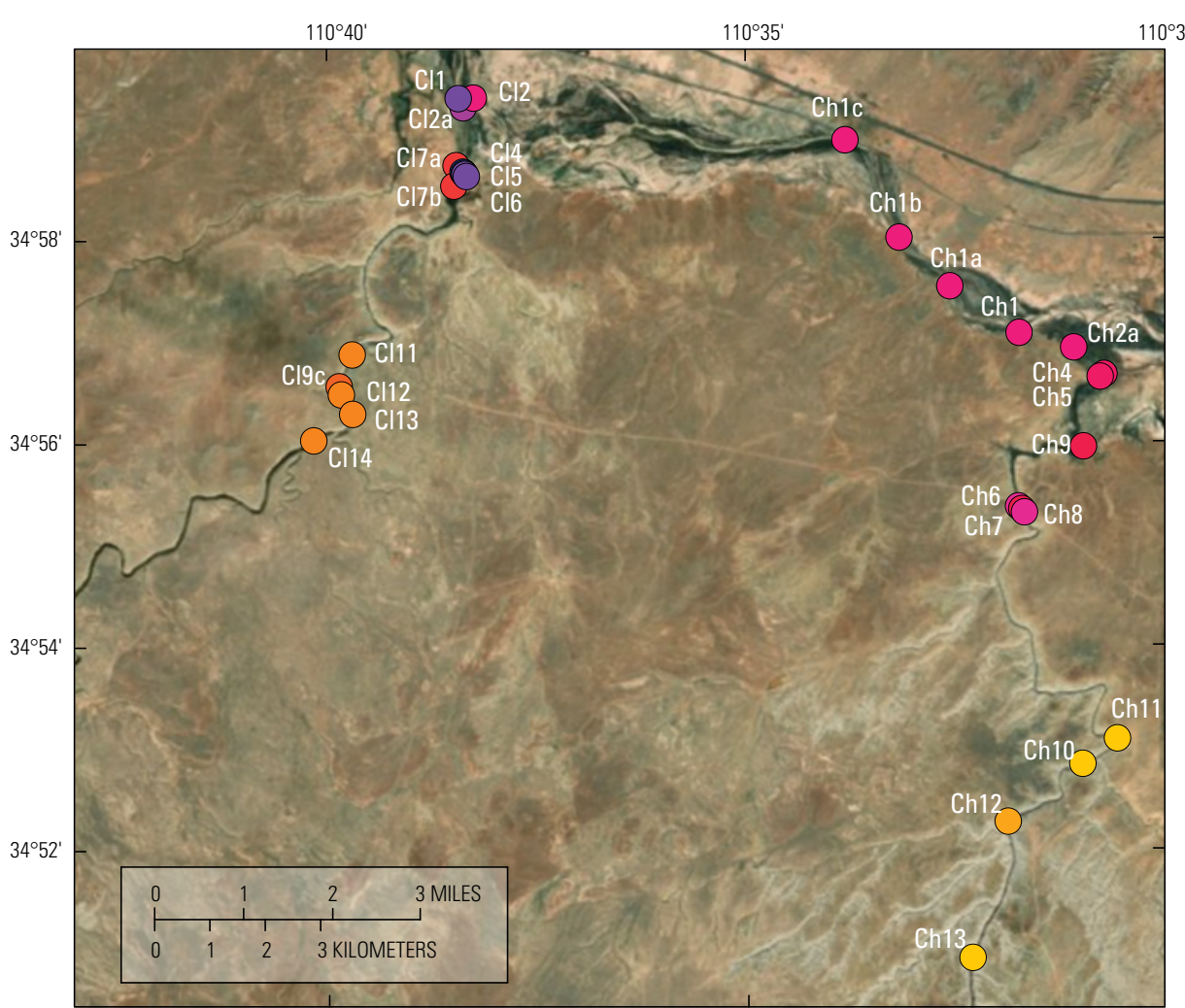

Base imagery from Esri, DigitalGlobe, GeoEye, Earthstar Geographics, CNES/Airbus DS, USDA, USGS, AeroGRID, IGN and the GIS User. World Geodetic System 84 Projection zone Mercator Auxillary Sphere

\section{EXPLANATION}

\section{C-Aquifer seepage sites}

Specific conductance $(\mu \mathrm{S} / \mathrm{cm})$
$640-1,000$
$3,501-4,000$
$1,001-1,500$
$4,001-4,500$
$1,501-2,000$
$4,501-5,000$
$2,001-2,500$
$5,001-5,500$
$2,501-3,000$
$3,001-3,500$
$5,501-6,000$
$6,001-6,500$

Figure 17. Map of median specific conductance in microsiemens per centimeter $(\mu \mathrm{S} / \mathrm{cm})$ along perennial reaches of Clear Creek, Chevelon Creek, and the Little Colorado River.

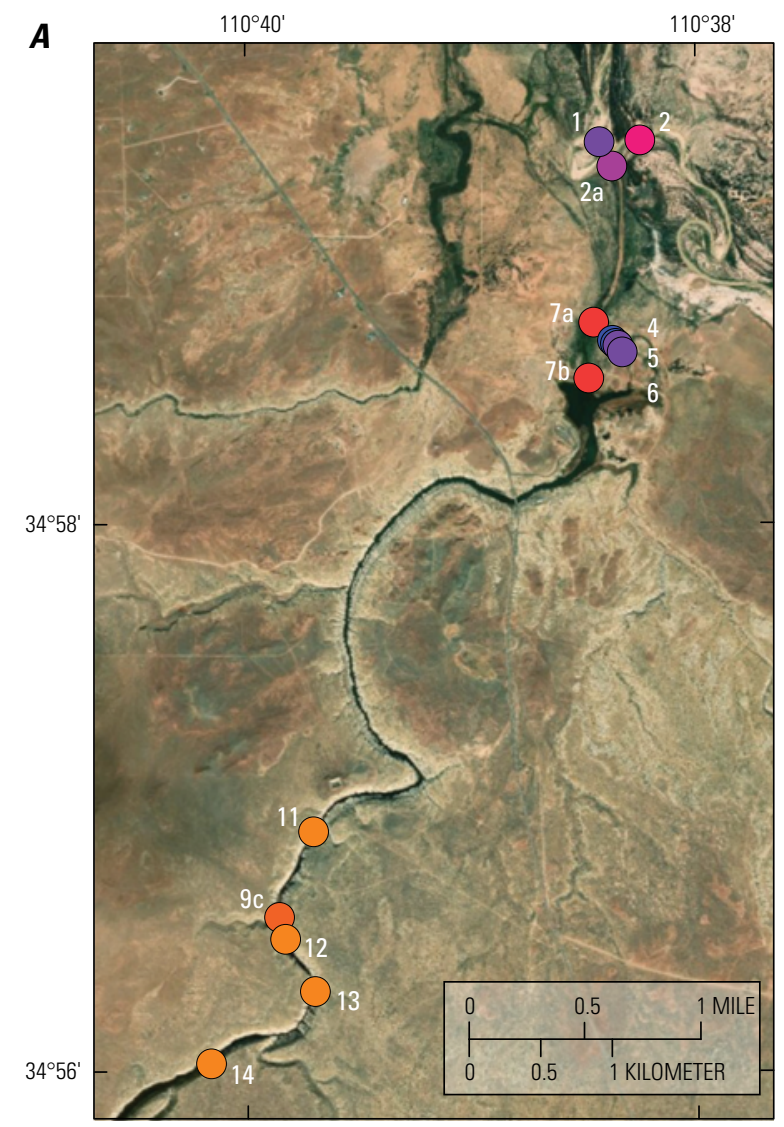

Base imagery from Esri, DigitalGlobe, GeoEye, Earthstar Geographics, CNES/Airbus DS, USDA, USGS, AeroGRID, IGN and the GIS User. World Geodetic System 84 Projection zone Mercator Auxillary Sphere

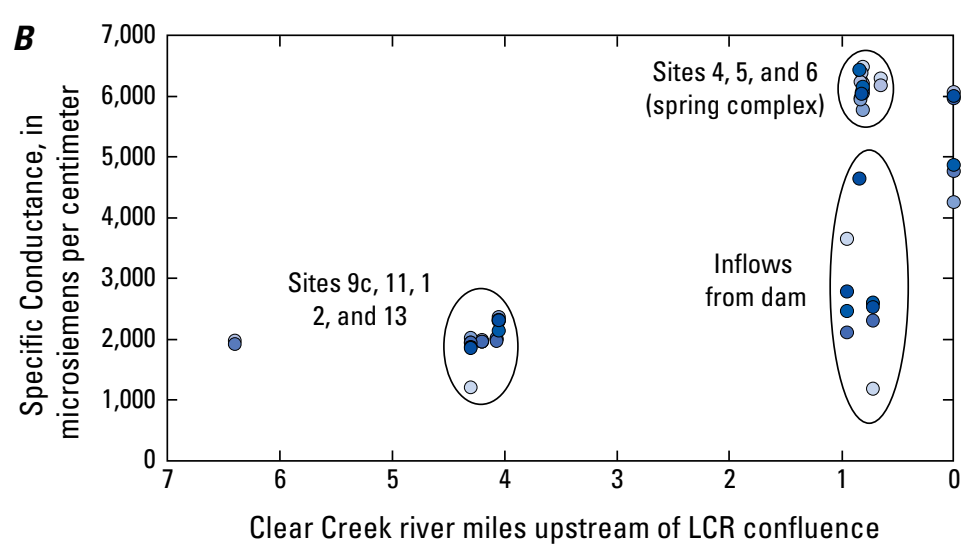

EXPLANATION

$\boldsymbol{A}$

Clear Creek seepage sites Specific conductance $(\mu \mathrm{S} / \mathrm{cm})$
$640-1,000$
$1,001-1,500$
$1,501-2,000$
$2,001-2,500$
$2,501-3,000$
$3,001-3,500$

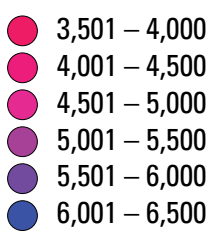

Figure 18. Median specific conductance $(\mu \mathrm{S} / \mathrm{cm})$ mapped along Clear Creek $(A)$ and plotted in graph form versus river miles upstream of the confluence of Clear Creek with the Little Colorado River $(B) . \mu \mathrm{S} / \mathrm{cm}$, microsiemens per centimeter; LCR, Little Colorado River. 
types; most notably, the sodium, chloride, and sulfate values are more than three times higher for the artesian spring (Clear Creek Site \#6) than farther up-stream (Clear Creek Site \#11). Mann (1976) describes halite beds that interfinger with the uppermost part of the Supai Formation and suggests that the increase in sodium and chloride content of the groundwater is likely the result of solution of these ions as groundwater moves through the halite beds. Recent studies have determined what is referred to here as the Holbrook salt basin, east of Chevelon Creek, to also include anhydrite, gypsum, and sylvite. As much as $650 \mathrm{ft}$ thick, the evaporite beds cover $3,500 \mathrm{mi}^{2}$ in area at depths of 700-800 ft (Conway and Cook, 2013; Neal and others, 2013). Clear Creek Sites \#7a, \#7b, and \#8 are all overflows from McHood Reservoir. Clear Creek Sites \#7a and \#7b typically have low discharge and are surrounded by vegetation, leading to an increase in evapotranspiration. Clear Creek Site \#8 flows over a concrete dam when McHood Reservoir is full. The dam is wide enough so that vehicles often drive across it, potentially introducing foreign matter that could affect the water-chemistry parameters. The variability in all these sites could explain the variability in specific conductance.

Chevelon Creek also shows a trend in specific conductance (figs. 19A and 19B). The lowest median specific conductance is $885 \mu \mathrm{S} / \mathrm{cm}$ at Chevelon Creek Site \#12; the highest is $4,735 \mu \mathrm{S} / \mathrm{cm}$ at Chevelon Creek Site \#8. Although no springs are obvious for direct measurement, the four most upstream sites have the lowest specific conductance values. Chevelon Creek Sites \#6 and \#8 enter the main channel from the Coconino Sandstone canyon walls approximately six miles downstream of Chevelon Creek Site \#12 and have much higher specific conductance values of around $4,750 \mu \mathrm{S} / \mathrm{cm}$. Although not as much as the spring complex (Clear Creek Sites \#4, \#5, and \#6) on Clear Creek, these springs also have much higher sodium, chloride, and sulfate concentrations than upstream sites (Brown and Macy, 2012).

Other field parameters ( $\mathrm{pH}$, dissolved oxygen, water temperature) do not show substantial trends along the reaches of Clear Creek, Chevelon Creek, or the Little Colorado River (fig. 20).

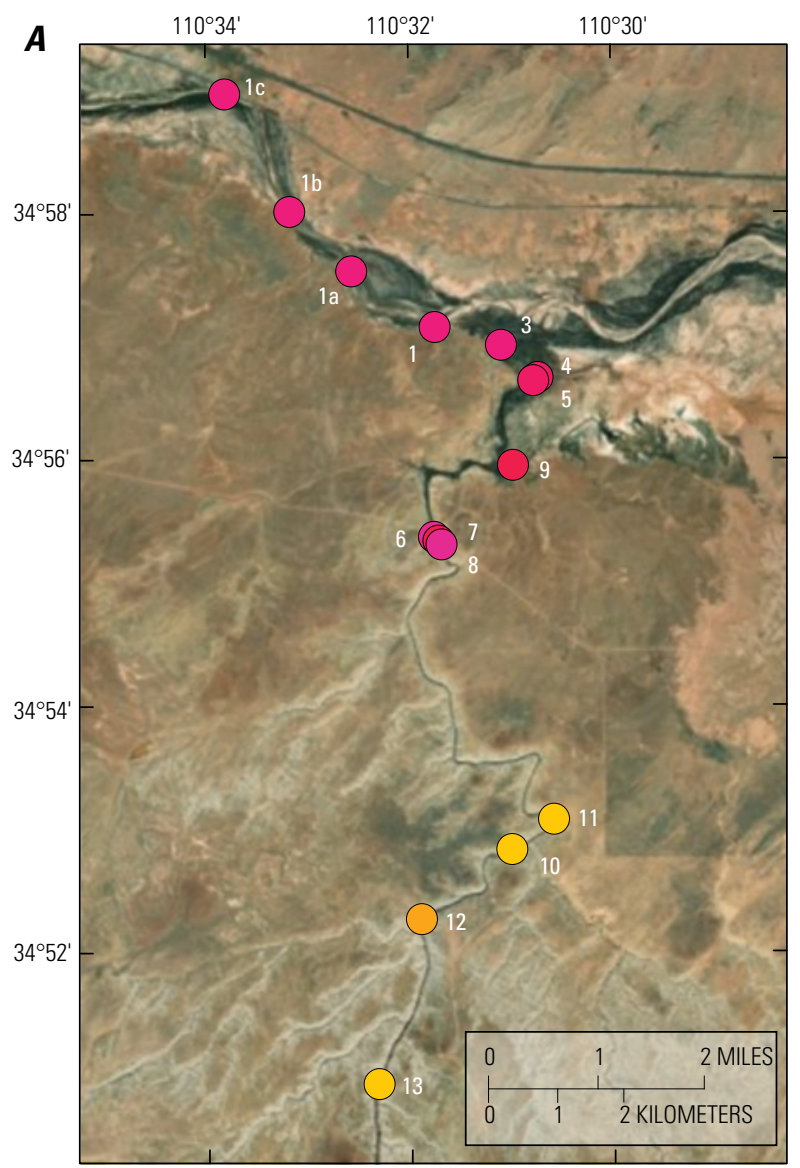

Base imagery from Esri, DigitalGlobe, GeoEye, Earthstar Geographics, CNES/Airbus DS, USDA, USGS, AeroGRID, IGN and the GIS User. World Geodetic System 84 Projection zone Mercator Auxillary Sphere

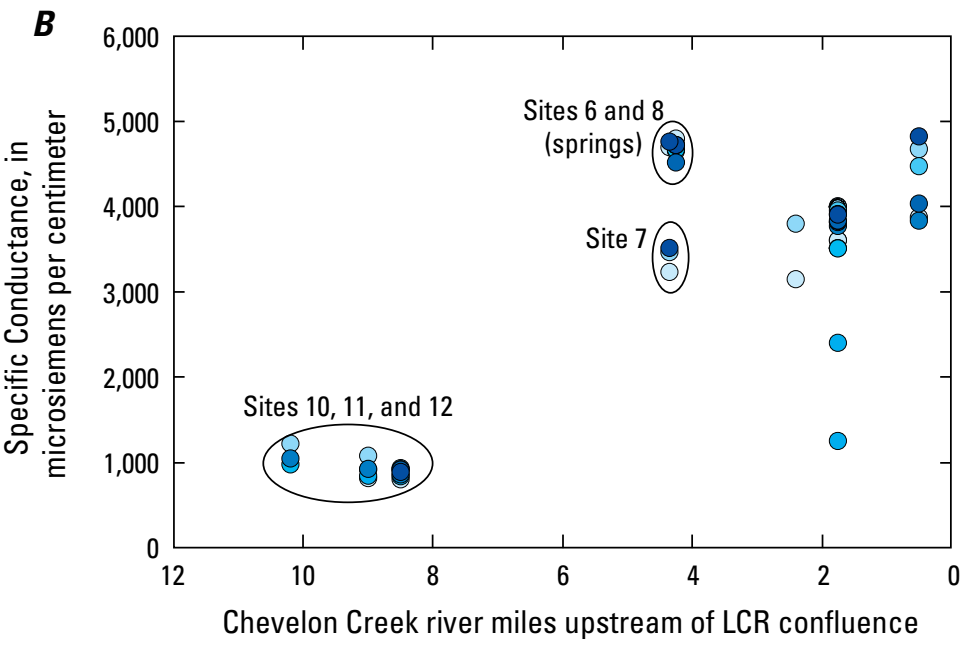

\section{EXPLANATION}

$\boldsymbol{A}$

\begin{tabular}{|c|c|}
\hline $\begin{array}{l}\text { Clear Creek see } \\
\text { Specific conduc }\end{array}$ & $\begin{array}{l}\text { sites } \\
(\mu S / c m)\end{array}$ \\
\hline $640-1,000$ & $3,501-4,000$ \\
\hline $1,001-1,500$ & $4,001-4,500$ \\
\hline $1,501-2,000$ & $4,501-5,000$ \\
\hline $2,001-2,500$ & $5,001-5,500$ \\
\hline $2,501-3,000$ & $5,501-6,000$ \\
\hline $3,001-3,500$ & $6,001-6,500$ \\
\hline
\end{tabular}

$\boldsymbol{B}$

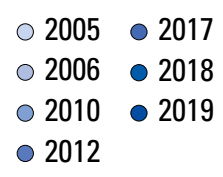

Figure 19. Median specific conductance in microsiemens per centimeter $(\mu \mathrm{S} / \mathrm{cm})$ mapped along Chevelon Creek $(A)$ and plotted in graph form versus river miles upstream of the confluence of Chevelon Creek with the Little Colorado River (B). LCR, Little Colorado River. 

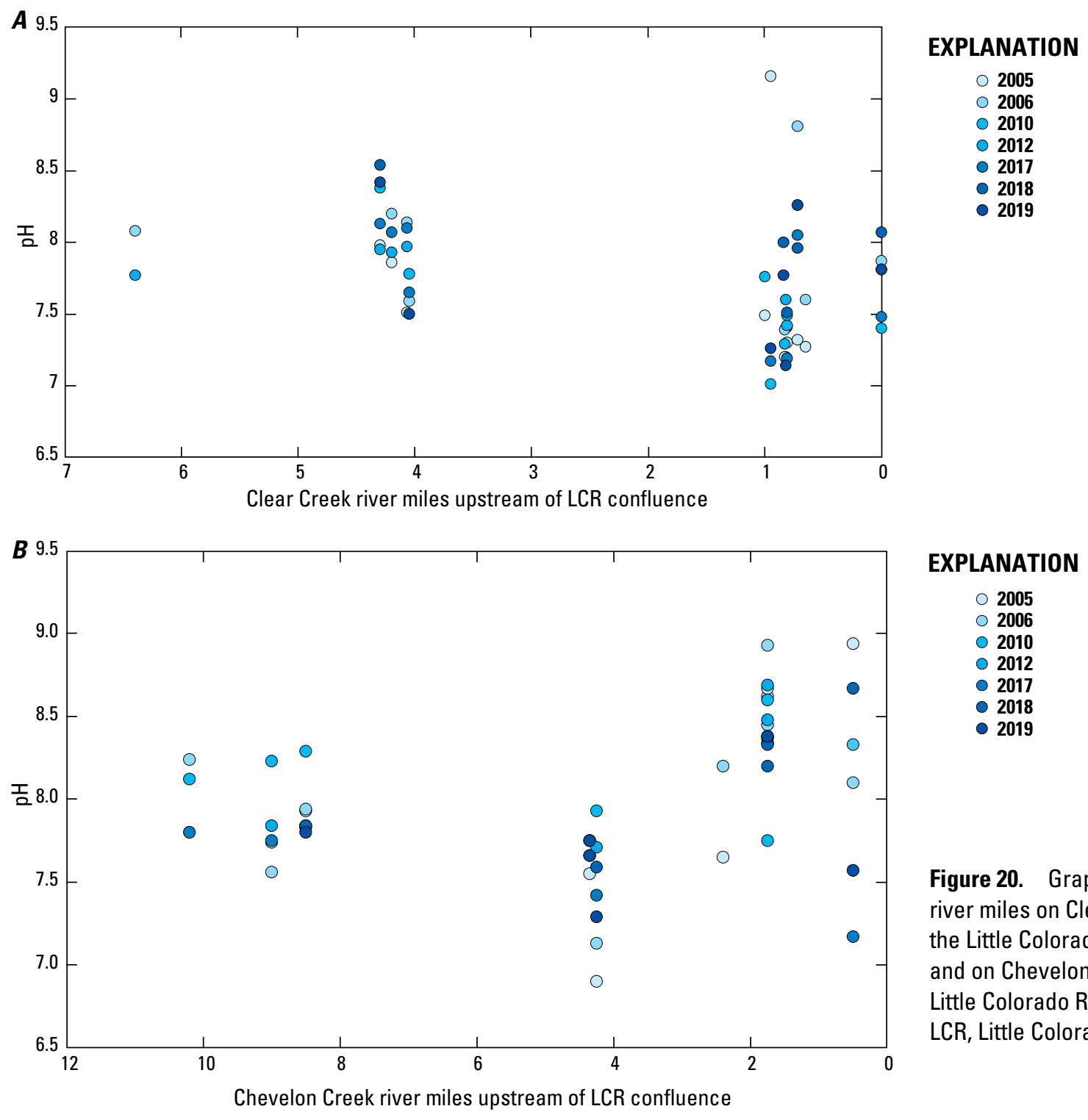

EXPLANATION

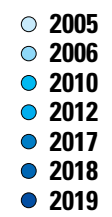

Figure 20. Graphs showing $\mathrm{pH}$ versus river miles on Clear Creek upstream of the Little Colorado River confluence $(A)$ and on Chevelon Creek upstream of the Little Colorado River confluence $(B)$. LCR, Little Colorado River.

\section{Summary}

This report presents data from an ongoing study by the U.S. Geological Survey (USGS) in cooperation with the Navajo Nation and the City of Flagstaff to monitor water quality and quantity within the $\mathrm{C}$ aquifer along the I-40 corridor from near St. Johns, Ariz., to Flagstaff, Ariz. The C aquifer is a regionally extensive aquifer supplying water for municipal, agricultural, and industrial use in northeastern Arizona, northwestern New Mexico, and southeastern Utah; the C-aquifer Monitoring Program monitors data for potential effects on aquifer storage from future population growth, commercial and industrial development, and a potentially changing climate. Data presented include water levels from 35 wells completed in the $\mathrm{C}$ aquifer and surface-water discharge and water-quality parameters from nine baseflow investigations of varying extent along perennial reaches of Clear Creek, Chevelon Creek, and the Little Colorado River. The C-aquifer Monitoring Program well network is composed of 17 wells measured quarterly. Of these wells, five are equipped to collect continuous data at 15-minute intervals. An additional 18 wells that were previously in the well network have been measured sporadically by USGS and other agencies and are included in this report when available. Changes in water-level measurements in the study area range from increasing water levels to a decrease of $81.20 \mathrm{ft}$ at Lake Mary 1 Well. The greatest changes in depth-to-water measurements can be observed around Flagstaff, a major pumping center, and in the eastern extent of the study area.

Nine baseflow investigations of varying extent were conducted between 2005 and 2019 along Clear Creek, Chevelon Creek, and the reach of the Little Colorado River 
between the confluences of the two tributaries. Both Clear Creek and Chevelon Creek gain in discharge from near the headwaters to outflow into the Little Colorado River. The Little Colorado River has a relatively steady discharge in the stretch between the two tributaries. Specific conductance increased along Clear Creek and Chevelon Creek. Water temperature, dissolved oxygen, and $\mathrm{pH}$ do not show significant trends along the reaches of Clear Creek, Chevelon Creek, or the Little Colorado River.

\section{References Cited}

Adams, D.K. and Comrie, A.C., 1997, The North American monsoon: Bulletin of the American Meteorological Society, v. 78 , no. 10 , p. $2197-2213$.

Alley, W.M., Reilly, T.E., and Franke, O.L., 1999, Sustainability of ground-water resources: U.S. Geological Survey Circular 1186, 79 p.

AMEC Geomatrix, Inc., 2012, Final groundwater modeling impact analysis, City of Flagstaff-Groundwater Sustainability Study, Coconino County, Arizona: Consulting report prepared for the City of Flagstaff.

Babcock, H.M., and Snyder, C.T., 1947, Ground-water resources of the Holbrook area, Navajo County, Arizona: U.S. Geological Survey Open-File Report (unnumbered), 27 p., 3 plates.

Billingsley, G.H., Breed, W.J., and Beasley, D., 1980, Geologic cross section along interstate 40-Kingman to Flagstaff, Arizona: Petrified Forest Museum Association.

Bills, D.J., and Flynn, M.E., 2002, Hydrogeologic data for the Coconino Plateau and adjacent areas, Coconino and Yavapai Counties, Arizona: U.S. Geological Survey Open-File Report 2002-265, 29 p.

Bills, D.J., Flynn, M.E., and Monroe, S.A., 2007, Hydrogeology of the Coconino Plateau and adjacent areas, Coconino and Yavapai Counties, Arizona: U.S. Geological Survey Scientific Investigations Report 2005-5222, 101 p., 4 plates.

Bills, D.J., Truini, Margot, Flynn, M.E., Pierce, H.A., Cathings, R.D., and Rymer, M.J., 2000, Hydrogeology of the regional aquifer near Flagstaff, Arizona, 1994-97: U.S. Geological Survey Water-Resources Investigations Report 00-4122, $142 \mathrm{p}$.

Brown, C.R. and Macy, J.P., 2012, Groundwater, surfacewater, and water-chemistry data from the $\mathrm{C}$-aquifer monitoring program, northeastern Arizona, 2005-2011 (ver. 1.1, March 2013): U.S. Geological Survey Open-File Report 2012-1196, 38 p.
Conway, B.D. and Cook, J.P., 2013, Monitoring evaporite karst activity and land subsidence in the Holbrook Basin, Arizona using Interferometric Synthetic Aperture Radar (InSAR): National Cave and Karst Research Institute, p. 187-194.

Cooley, M.E., Harshbarger, J.W., Akers, J.P., Hardt, W.F., and Hicks, O.N., 1969, Regional hydrogeology of the Navajo and Hopi Indian Reservations, Arizona, New Mexico, and Utah: U.S. Geological Survey Professional Paper 521-A, $61 \mathrm{p}$.

Cunningham, W.L., and Schalk, C.W, 2011, Groundwater technical procedures of the U.S. Geological Survey: U.S. Geological Survey Techniques and Methods 1-A1, 151 p.

Darton, N.H., 1910, A reconnaissance of parts of northwestern New Mexico and northern Arizona: U.S. Geological Survey Bulletin 435, $88 \mathrm{p}$.

Fenneman, N.M. and Johnson, D.W., 1946, Physiographic divisions of the conterminous U. S.: U.S. Geological Survey, scale 1:700,000.

Goodrich, G.B., 2004, Modulation of the winter ENSO climate signal by the Pacific Decadal Oscillation: Journal of the Arizona-Nevada Academy of Science, v. 36, no. 2, p. 88-94.

Gregory, H.E., 1916, The Navajo country-A geographic and hydrographic reconnaissance of parts of Arizona, New Mexico, and Utah: U.S. Geological Survey Water-Supply Paper 380, 219 p.

Harrell, M.A., and Eckel, E.B., 1939, Ground-water resources of the Holbrook region, Arizona: U.S. Geological Survey Water-Supply Paper 836-B, 105 p.

Hart, R.J., Ward, J.J., Bills, D.J., and Flynn, M.E., 2002, Generalized hydrogeology and ground-water budget for the C Aquifer, Little Colorado River basin and parts of the Verde and Salt River basins, Arizona and New Mexico: U.S. Geological Survey Water-Resources Investigations Report 2002-4026, 45 p.

Hoffmann, J.V., Bills, J.P., Phillips, D.J., and Halford, K.J., 2006, Geologic, hydrologic, and chemical data from the C aquifer, near Leupp, Arizona: U.S. Geological Survey Scientific Investigations Report 2005-5280, 49 p.

Johnson, P.W., 1962, Water in the Coconino Sandstone for the Snowflake-Hay Hollow area, Navajo County, Arizona: U.S Geological Survey Water-Supply Paper 1539-S, 46 p., 4 pls.

Leake, S.A., Hoffmann, J.P., and Dickinson, Jesse, E., 2005, Numerical ground-water change model of the $\mathrm{C}$ aquifer and effects of ground-water withdrawals on stream depletion in selected reaches of Clear Creek, Chevelon Creek, and the Little Colorado River, northeastern Arizona; U.S. Geological Survey Scientific Investigations Report 20055277, 39 p. 
Mann, L.J., 1976, Ground-water resources and water use in southern Navajo County, Arizona: Phoenix, Arizona Water Commission Bulletin 10, 106 p.

Mann, L.J., 1979, Water budget and mathematical model of the $\mathrm{C}$ aquifer, southern Navajo County, Arizona: U.S. Geological Survey Open-File Report 79-348, 58 p.

Mann, L.J., and Nemecek, E.A., 1983, Geohydrology and water use in southern Apache County, Arizona: Phoenix, Arizona Department of Water Resources Bulletin 1, 86 p.

McCabe, G.J., Palecki, M.A., and Betancourt, J.L., 2004, Pacific and Atlantic Ocean influences on multidecadal drought frequency in the United States: Proceedings of the National Academy of Sciences, v. 101, no. 12, p. 4136-4141.

McGavock, E.H., Anderson, T.W., Moosburner, Otto, and Mann, L.J., 1986, Water resources of southern Coconino County, Arizona: Phoenix, Arizona Department of Water Resources Bulletin 4, 53 p.

Peter Mock Groundwater Consulting, Inc., 2003, Report of findings for the assessment of western Navajo-Hopi water supply needs, alternatives, and impacts: HDR Engineering, Inc., v. 3, appendix B-3, variously paged.

Neal, J.T. and Johnson, K.S., 2002, McCauley Sinks-A compound breccia pipe in evaporite karst, Holbrook Basin, Arizona, USA: Carbonates and Evaporites, v. 17, no. 2, p. 98-106.

Neal, J.T., Johnson, K.S., and Lindberg, P., 2013, Variations in evaporite karst in the Holbrook Basin, Arizona, in Land, L., Doctor, D.H., and Stephenson, J.B., eds., Sinkholes and the engineering and environmental impacts of karst: National Cave and Karst Research Institute, p. 177-186.

Pool, D.R., 2016, Simulation of groundwater withdrawal scenarios for the Redwall-Muav and Coconino aquifer systems of northern and central Arizona: U.S. Geological Survey Scientific Investigations Report 2016-5115, 38 p., accessed at https://doi.org/10.3133/sir20165115.
Pool, D.R., Blasch, K.W., Callegary, J., Leake, S.A., and Glaser, L., 2011, Regional groundwater-flow model of the Redwall-Muav, Coconino, and Alluvial Basin aquifer systems of northern and central Arizona: U.S. Geological Survey Scientific Investigations Report 2010-5180, v. 1.1, $101 \mathrm{p}$.

PRISM Climate Group, 2018, Norm81m: PRISM Climate Group, Oregon State University, accessed December 27, 2019, at http://prism.oregonstate.edu.

Southwest Groundwater Consultants, Inc., 2003, Report of findings for the assessment of western Navajo-Hopi water supply needs, alternatives, and impacts: HDR Engineering, Inc for U.S. Bureau of Reclamation, v. 3, 10 p.

Southwest Ground-water Consultants, Inc., 2015, Red Gap Ranch-Leupp water resources environmental assessment groundwater flow model: Consultant's report prepared for City of Flagstaff, $153 \mathrm{p}$.

S.S. Papadopulos and Associates, Inc., 2005, Groundwater flow model of the $\mathrm{C}$ aquifer in Arizona and New Mexico: Consulting report prepared for the Salt River Project on behalf of, and for the use of the Mohave Generating station co-owners, $121 \mathrm{p}$.

U.S. Drought Monitor, 2019, Quarterly climate impacts and outlook for the Western Region-December 2019: National Oceanic and Atmospheric Administration, $2 \mathrm{p}$.

US Fish and Wildlife Service, 1987, Endangered and threatened wildlife and plants; final rule to determine Lepidomeda vittata to be a threatened species with critical habitat. Federal Register v. 52, no.179, p.35034-35041. 
Moffett Field Publishing Service Center, California Manuscript approved April 15, 2021

Edited by Aditya Navale

Layout and design by Kimber Petersen 
